
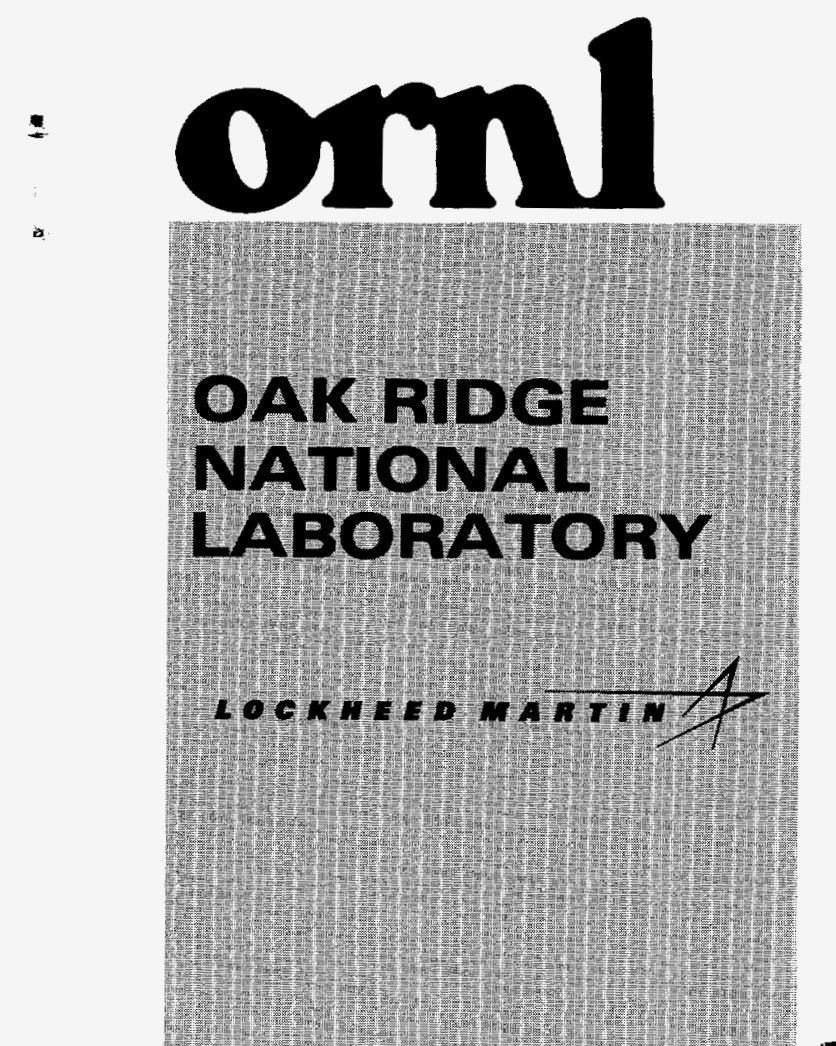

\title{
Active Sites Environmental Monitoring Program FY 1997 Annual Report
}

\section{RECEIVED \\ APR $0>1998$ \\ OSTI} \\ C. M. Morrissey \\ G. R. Cunningham
}

Environmental Sciences Division

Publication No. 4714

\section{MASTER}

DISTRIBUTION OF THIS DOCUMENT IS UNLIMTED

WANAGED ANO OPERATED BY

LOCKHEED WARTIN EMERGY RESEARCH CORPOBATION FOR THE UNTED STATES

DEPARTIENT OF ENERGY

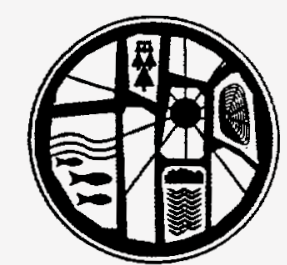


This report has been reproduced directly from the best available copy.

Available to DOE and DOE contractors from the Office of Scientific and Technical Information, P.O. Box 62, Oak Ridge. TN 37831; prices available from (423) 576-8401, FTS 626-8401.

This report was prepared as an account of work sponsored by an agency of the United States Government. Neither the United States Government nor any agency thereof, nor any of their employees, makes any warranty, express or implied, or assumes any legal liability or responsibility for the accuracy, completeness, or usefulness of any information, apparatus, product, or process disclosed, or represents that its use would not infringe privately owned rights. Reference herein to any specific commercial product, process, or service by trade name, trademark, manufacturer, or otherwise, does not necessarily constitute or imply its endorsement, recommendation, or favoring by the United States Government or any agency thereof. The views and opinions of authors expressed herein do not necessarily state or reflect those of the United States Govemment or any agency thereof. 


\section{DISCLAIMER}

Portions of this document may be illegible electronic image products. Images are produced from the best available original document. 
ORNL/M-6163

Environmental Sciences Division

\title{
ACTIVE SITES ENVIRONMENTAL MONITORING PROGRAM FY 1997 ANNUAL REPORT
}

\author{
C. M. Morrissey and D. S. Marshall \\ Environmental Sciences Division \\ G. R. Cunningham \\ Waste Management and Remedial Action Division \\ Environmental Sciences Division \\ Publication No. 4714 \\ Date Published: March 1998 \\ Prepared for \\ Office of Environmental Management \\ (EW 312004 1) \\ Prepared by the \\ OAK RIDGE NATIONAL LABORATORY \\ Oak Ridge, Tennessee 37831 \\ managed by \\ Lockheed Martin Energy Research Corp. \\ for the \\ U.S. DEPARTMENT OF ENERGY \\ under contract DE-AC05-96OR22464
}




\section{CONTENTS}

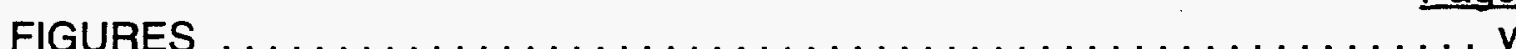

TABLES $\ldots \ldots \ldots \ldots \ldots \ldots \ldots \ldots \ldots \ldots \ldots \ldots \ldots \ldots \ldots \ldots$

ABBREVIATIONS AND ACRONYMS $\ldots \ldots \ldots \ldots \ldots \ldots \ldots \ldots \ldots$ ix

EXECUTIVE SUMMARY $\ldots \ldots \ldots \ldots \ldots \ldots \ldots \ldots \ldots \ldots \ldots \ldots \ldots \ldots$

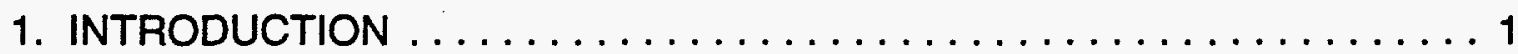

2. SWSA 6 LOW-LEVEL WASTE FACILITIES $\ldots \ldots \ldots \ldots \ldots \ldots \ldots \ldots \ldots$

2.1 INTERIM WASTE MANAGEMENT FACILITY $\ldots \ldots \ldots \ldots \ldots \ldots \ldots$

2.1.1 Pad and Underpad Runoff ................. 3

2.1.1.1 Methodology ..................... 3

2.1.1.2 Results ......................... 4

$2.1 .2 \mathrm{pH}$ control of pad water runoff $\ldots \ldots \ldots \ldots \ldots \ldots \ldots \ldots$

2.1.2.1 Methodology .......................6 6

2.1 .2 .2 Results ......................... 6

2.1 .3 Soil sampling $\ldots \ldots \ldots \ldots \ldots \ldots \ldots \ldots \ldots \ldots \ldots \ldots$

2.1.3.1 Methodology ...................... 7

2.1.3.2 Results .......................... . 7

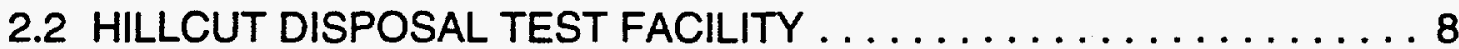

2.2.1 Pad and underpad runoff collection and analysis . . . . . . . . 9

2.2.1.1 Methodology ...................... 9

2.2.1.2 Results .......................... 9

2.3 CONCLUSIONS .........................

3. TRANSURANIC WASTE FACILITIES IN SWSA 5 NORTH . . . . . . . 10

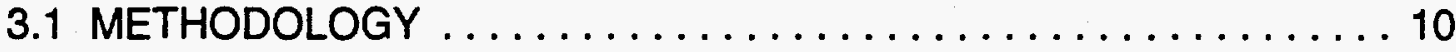

3.2 RESULTS . . . . . . . . . . . . . . . . . . . . . 11

3.2.1 Storage Facility Sumps . . . . . . . . . . . . . . . . 11

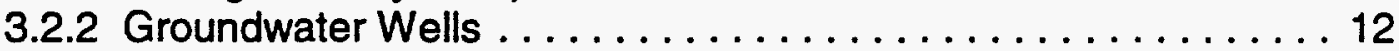

3.3 CONCLUSIONS ........................ 12

4. ACKNOWLEDGMENTS $\ldots \ldots \ldots \ldots \ldots \ldots \ldots \ldots \ldots \ldots \ldots \ldots$

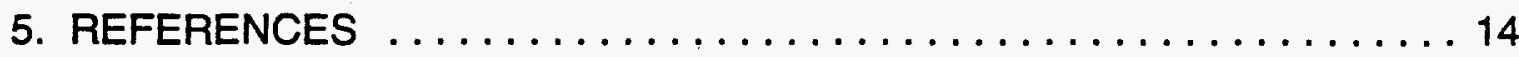

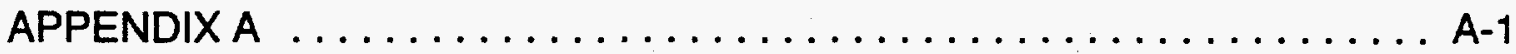

APPENDIX B .......................... 


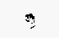




\section{FIGURES}

Figure

Page

A.1 Aerial view of SWSA $6 \ldots \ldots \ldots \ldots \ldots \ldots \ldots \ldots \ldots \ldots \ldots \ldots$

A.2 Active low-level waste disposal sites in SWSA $6 \ldots \ldots \ldots \ldots \ldots$ A-4

A.3 Aerial view of the IWMF area $\ldots \ldots \ldots \ldots \ldots \ldots \ldots \ldots \ldots \ldots$ A-5

A.4 IWMF stormwater sump gross alpha data $\ldots \ldots \ldots \ldots \ldots \ldots \ldots$ A-6

A.5 IWMF infiltration sump gross alpha data $\ldots \ldots \ldots \ldots \ldots \ldots \ldots$ A-7

A.6 IWMF stormwater sump gross beta data $\ldots \ldots \ldots \ldots \ldots \ldots \ldots$ A-8

A.7 IWMF infiltration sump gross beta data $\ldots \ldots \ldots \ldots \ldots \ldots \ldots \ldots$

A.8 IWMF stormwater sump ${ }^{40} \mathrm{~K}$ data $\ldots \ldots \ldots \ldots \ldots \ldots \ldots \ldots \ldots$

A.9 IWMF infiltration sump ${ }^{40} \mathrm{~K}$ data $\ldots \ldots \ldots \ldots \ldots \ldots \ldots \ldots \ldots \ldots \ldots \ldots$

A.10 IWMF stormwater sump ${ }^{60} \mathrm{Co}$ data. . . . . . . . . . . . A-12

A.11 IWMF infiltration sump ${ }^{60} \mathrm{Co}$ data. $\ldots \ldots \ldots \ldots \ldots \ldots \ldots \ldots \ldots \ldots \ldots \ldots \ldots$

A.12 IWMF stormwater sump ${ }^{137} \mathrm{Cs}$ data $\ldots \ldots \ldots \ldots \ldots \ldots \ldots \ldots$ A-14

A.13 IWMF infiltration sump ${ }^{137} \mathrm{Cs}$ data $\ldots \ldots \ldots \ldots \ldots \ldots \ldots \ldots \ldots \ldots \ldots \ldots \ldots \ldots \ldots$

A.14 IWMF stormwater sump ${ }^{3} \mathrm{H}$ data $\ldots \ldots \ldots \ldots \ldots \ldots \ldots \ldots \ldots$ A-16

A.15 IWMF infiltration sump ${ }^{3} \mathrm{H}$ data $\ldots \ldots \ldots \ldots \ldots \ldots \ldots \ldots \ldots \ldots$ A-17

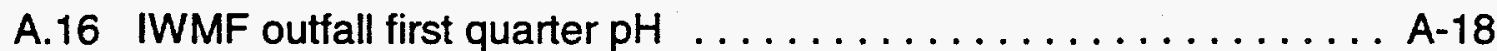

A.17 IWMF stormwater sump first quarter $\mathrm{pH} \ldots \ldots \ldots \ldots \ldots \ldots$. . . 19

A.18 IWMF infiltration sump first quarter $\mathrm{pH} \ldots \ldots \ldots \ldots \ldots \ldots \ldots \ldots$ A-20

A.19 IWMF outfall second quarter $\mathrm{pH} \ldots \ldots \ldots \ldots \ldots \ldots \ldots \ldots \ldots$ A-21

A.20 IWMF stormwater sump second quarter $\mathrm{pH} \ldots \ldots \ldots \ldots \ldots \ldots \ldots$ A-22

A.21 IWMF infiltration sump second quarter $\mathrm{pH} \ldots \ldots \ldots \ldots \ldots \ldots \ldots$ A-23

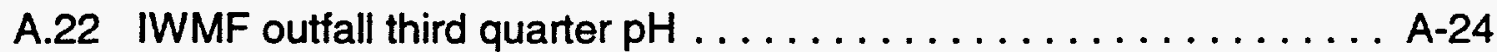

A.23 IWMF stormwater sump third quarter $\mathrm{pH} \ldots \ldots \ldots \ldots \ldots \ldots \ldots$ A-25

A.24 IWMF infiltration sump third quarter $\mathrm{pH} \ldots \ldots \ldots \ldots \ldots \ldots \ldots$ A-26

A.25 IWMF outfall fourth quarter $\mathrm{pH} \ldots \ldots \ldots \ldots \ldots \ldots \ldots \ldots \ldots \ldots \ldots \ldots \ldots \ldots \ldots \ldots$

A.26 IWMF stormwater sump fourth quarter $\mathrm{pH} \ldots \ldots \ldots \ldots \ldots \ldots \ldots$ A-28

A.27 IWMF infiltration sump fourth quarter $\mathrm{pH} \ldots \ldots \ldots \ldots \ldots \ldots \ldots$. . . . . . .

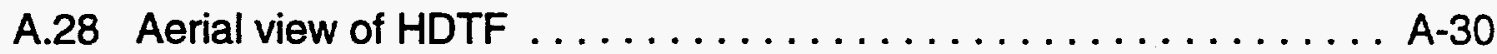

A.29 Cross section through HDTF . . . . . . . . . . . . . A-31

A.30 Transuranic waste storage areas, groundwater monitoring wells, and other major facilities in SWSA $5 \mathrm{~N} \ldots \ldots \ldots \ldots \ldots \ldots \ldots$ A-32

A.31 Aerial view of SWSA 5 North $\ldots \ldots \ldots \ldots \ldots \ldots \ldots \ldots \ldots$ A-33 


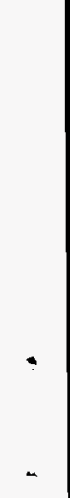




\section{TABLES}

Table

Page

B.1 Runoff and French drain samples from the IWMF ........... B-3

B.2 Soil radionuclide data from the IWMF area $\ldots \ldots \ldots \ldots \ldots \ldots$ B-9

B.3 Runoff samples from the Hillcut Disposal Test Facility $\ldots \ldots \ldots$. . B-10

B.4 Radionuclide data for water from SWSA $5 \mathrm{~N}$ building sumps $\ldots \ldots$ B-11

B.5 Radionuclide data for SWSA $5 \mathrm{~N}$ groundwater $\ldots \ldots \ldots \ldots \ldots$ B-14

B.6 Radionuclide data for SWSA $5 \mathrm{~N}$ seeps $\ldots \ldots \ldots \ldots \ldots \ldots \ldots$ B-14

B.7 Analytical data for SWSA $5 \mathrm{~N}$ groundwater $\ldots \ldots \ldots \ldots \ldots \ldots$ B-15 


\section{ABBREVIATIONS AND ACRONYMS}

ASO Analytical Services Organization

ASEMP Active Sites Environmental Monitoring Program

DOE U.S. Department of Energy

ER Environmental Restoration

ESD Environmental Sciences Division

FY fiscal year

HDTF Hillcut Disposal Test Facility

IWMF Interim Waste Management Facility

IRL Internal Reporting Level

LWOG Liquid Waste Operations Group

LLW low-level waste

MDA Minimum Detectable Amount

NPDES National Pollutant Discharge Elimination System

ORNL Oak Ridge National Laboratory

PWTP Process Waste Treatment Plant

QA quality assurance

RCRA Resource Conservation and Recovery Act

RSWOG radioactive solid waste operations group

SWSA Solid Waste Storage Area

TRU transuranic

UND underpad

WOC White Oak Creek

WMRAD Waste Management and Remedial Action Division 


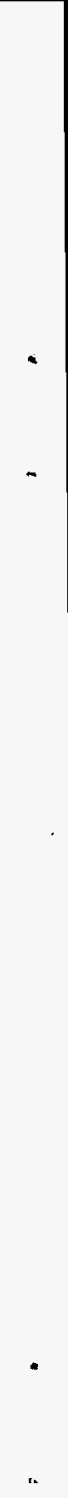


This report summarizes the activities conducted by the Active Sites Environmental Monitoring Program (ASEMP) from October 1996 through September 1997. The Radioactive Solid Waste Operations Group (RSWOG) of the Waste Management and Remedial Action Division (WMRAD) and the Environmental Sciences Division (ESD) at Oak Ridge National Laboratory (ORNL) established ASEMP in 1989 in response to U.S. Department of Energy (DOE) Order 5820.2A. The purpose of the program is to provide early detection and performance monitoring at active low-level waste (LLW) disposal sites in Solid Waste Storage Area (SWSA) 6 and transuranic (TRU) waste storage sites in SWSA 5 North as required by Chapters II and III of 5820.2A.

Monitoring results from the Interim Waste Management Facility (IWMF) disposal pads indicated that no LLW leached from the waste-containing storage vaults. None of the 83 IWMF pad runoff samples collected in FY 1997 exceeded Internal Reporting Levels (IRLs) for gross alpha, gross beta, ${ }^{137} \mathrm{Cs}$, or ${ }^{60} \mathrm{Co}$ activity.

The absence of water in the IWMF underpad collection system indicated that the French drain functioned as designed to suppress the groundwater table and prevent contact of groundwater with the undersurface of the pads. Samples collected from the French drain showed gross radiological activity consistent with uncontaminated shallow groundwater in the SWSA 6 area. Surface soil sampling around the IWMF pads indicated no radionuclide contamination of the surrounding area.

The $\mathrm{CO}_{2} \mathrm{pH}$ control system at IWMF continued to be an effective means of controlling elevated $\mathrm{pH}$ in runoff water from the pads. The $\mathrm{CO}_{2}$ bubbling system was installed in 1993 as a "best management practice" to maintain pad runoff water pH below the National Pollutant Discharge Elimination System (NPDES) permit limit. The system is electronically controlled in response to a high $\mathrm{pH}$ in water flowing from the pads.

Hillcut Disposal Test Facility (HDTF) runoff water samples continued to be collected and analyzed for radiological constituents. A total of $\sim 5000$ gal. of water drained from the HDTF pad and underpad collection system in FY 1997. Runoff from the pad occurs in significant volumes only during winter and spring. All samples of pad and underpad runoff water were well below the IRLs for all radiological parameters.

Sumps that drain TRU storage areas in SWSA $5 \mathrm{~N}$ continue to be free from any waste-related radiological contamination. One sump consistently shows elevated levels of gross beta activity. The presence of ${ }^{40} \mathrm{~K}$ and the color of the water in this sump indicate that the activity is related to leaching from soil or vegetation. 
Groundwater monitoring at SWSA $5 \mathrm{~N}$ continued to show elevated gross alpha activity in well 516. The source of the alpha activity is primarily ${ }^{244} \mathrm{Cm}$ with traces of ${ }^{241} \mathrm{Am}$ also present. This well is hydrologically downgradient from the TRU waste disposal trenches. Traces of ${ }^{244} \mathrm{Cm}$, ${ }^{241} \mathrm{Am}$, and associated alpha activity were also detected in a seep downgradient from the SWSA $5 \mathrm{~N}$ trenches at the bank of White Oak Creek. 


\section{INTRODUCTION}

Chapter III of U.S. Department of Energy (DOE) Order 5820.2A (DOE 1988) specifies requirements for the management of facilities that were used for the disposal of radioactive solid low-level waste (LLW) on or after the date of the order (September 26, 1988). Activities in Solid Waste Storage Area (SWSA) 6 at Oak Ridge National Laboratory (ORNL) are governed by Chapter III. Chapter II of 5820.2A covers the transuranic (TRU) waste storage areas in SWSA 5 North at ORNL. Both chapters require environmental monitoring to provide early warning of leaks before such leaks pose a threat to human health or the environment. Chapter III also requires monitoring of LLW disposal facilities so that their performance can be evaluated. In order to comply with 5820.2A, the Environmental Sciences Division (ESD) at ORNL implements the Active Sites Environmental Monitoring Program (ASEMP) for the Radioactive Solid Waste Operations Group (RSWOG) within the Waste Management and Remedial Action Division (WMRAD) at ORNL. The scope of ASEMP includes all ORNL waste disposal sites that were active on or after the date of the Order and that are under the operational control of RSWOG of WMRAD.

This report continues a series of annual and semiannual reports that present the results of ASEMP monitoring activities (Wickliff et al. 1991a, 1991b; Ashwood et al. 1991a, 1991b, 1992a, 1992b; Morrissey et al. 1994a, 1994b, 1995, 1996, 1997; Yager et al. 1989). This report details monitoring results for fiscal year (FY) 1997 from SWSA 6, including the Interim Waste Management Facility (IWMF) and the Hillcut Disposal Test Facility (HDTF), and (2) TRU-waste storage areas in SWSA $5 \mathrm{~N}$. The detailed monitoring methodology is described in updated ASEMP monitoring procedures on file in the project manager's office. This report presents a summary of the methodology used to gather data for each major area along with the FY 1997 results. Figures referenced in the text are found in Appendix $A$ and data tables are presented in Appendix B.

\section{SWSA 6 LOW-LEVEL WASTE FACILITIES}

SWSA 6 is a 68-acre LLW disposal area at ORNL that opened in 1969 and began fullscale operations in 1973. A wide variety of wastes have been disposed at SWSA 6 including LLW and chemical and biological wastes. Disposal units consist of unlined trenches, auger holes, silos, concrete casks, and tumulus-type facilities. Figure A.1, Appendix A, is an aerial view of SWSA 6 showing Resource Conservation and Recovery Act (RCRA) plastic caps covering old burial trenches, below-grade high- and low-activity silos, tumulus facilities under an earthen cap, Liquid Waste Solidification Project (LWSP) casks, the IWMF area, the HDTF area, and various support buildings. The capped 
areas, disposal silos, and tumulus pads area no longer monitored as part of ASEMP. These are not "active" disposal areas and are under the institutional control of the Environmental Restoration Program.

Monitoring activities associated with SWSA 6 facilities are divided into three major areas: IWMF, LWSP, and HDTF. Low-activity wastes are currently placed in concrete vaults on the aboveground IWMF concrete pads. Monitoring runoff from the IWMF is a major function of ASEMP. During the mid-1980s, high-activity wastes were stored in concrete vaults (similar to tumulus vaults) placed on a concrete pad cut into the side of a hill as a demonstration of this method of disposal. The HDTF is not an active site, but has historically been included in ASEMP. The LWSP casks and storage area are functionally similar to the earlier EASC/LWSP facility in Melton Valley, and are discussed in Section 3. No samples of liquid were collected from the LWSP casks in FY 1997. Sampling is scheduled to resume in FY 1998. Figure A.2, Appendix A, is a drawing of SWSA 6 showing the relative location of these facilities.

IWMF monitoring includes pad water runoff sampling and $\mathrm{pH}$ control, French drain outfall sampling, underpad drainage system sampling, and soil sampling around the facility. At HDTF, water that accumulates on the pad or in the underpad area is collected and sampled.

\subsection{INTERIM WASTE MANAGEMENT FACILITY}

IWMF has been in operation since December 1991. The concrete vaults containing LLW in a grout mixture and the supporting concrete pads are patterned after the earlier tumulus-type facilities. The concrete vaults are stacked three high on the pads so that 330 waste-containing vaults can be loaded onto each pad. Eventually, the IWMF pads will be covered with an engineered cap designed to minimize infiltration of rainwater.

Because the IWMF facility is above ground, the primary method of contaminant transport is rainwater falling on the pads and vaults. The pads and vaults are not covered during loading operations and are thus open to direct precipitation. Resulting runoff from the pads is directed through piping to a monitoring shed where samples are collected by an electronically controlled automatic sampler that activates when flow from the pads is detected. Runoff flows through collection basins (sumps) at the monitoring shed, exits IWMF through a National Pollutant Discharge Elimination System (NPDES) sampling point, and, ultimately, discharges to a nearby surface stream. Figure A.3, Appendix $A$, is a recent aerial view of the IWMF area showing three fully-loaded pads, one pad actively being loaded, and two empty pads. The locations of the piping gallery, the French drain outfall, and the monitoring shed are also shown in relation to the pads. The French drain is located beneath the portion of the piping gallery that is behind the 
pads. The location of the IWMF area in the southwest corner of SWSA 6 was shown in Figure A.2.

The IWMF French drain is designed to prevent groundwater from entering the gravel base beneath the pads, a feature that was not incorporated into the earlier tumulus design. If water should enter the gravel base, it would drain to an underpad collection basin (sump) at the monitoring station.

Historically, values of $\mathrm{pH}$ exceeding the NPDES permit limit of 9.0 have been reported for both the IWMF and the original tumulus pads (Ashwood et al. 1991a, 1991b; Wickliff et al. 1991a, 1991b; Morrissey et al., 1994a, 1994b, 1995, 1996, 1997). An automated $\mathrm{CO}_{2}$ bubbling system was installed at IWMF in 1993 and operates as a "best management practice" to lower pad runoff $\mathrm{pH}$ by supplying $\mathrm{CO}_{2}$ to the runoff water. The $\mathrm{CO}_{2}$ supply is electronically controlled to input gas to the runoff water when the effluent from either pad approaches the NPDES limit of 9.0.

\subsubsection{Pad and Underpad Runoff}

\subsubsection{Methodology}

The IWMF monitoring area consists of three basins (sumps) for the collection of water from (1) the active pad (i.e., the pad on which waste vaults are actively being loaded) and the empty pads, (2) the inactive (i.e., fully loaded) pads, and (3) the underpad areas. The design of the IWMF pad drainage system allows runoff from the active and empty pads to flow through PVC piping into a sump, designated the stormwater sump, at the monitoring station. Runoff from the inactive pads drains to a separate sump, designated the infiltration sump, at the monitoring station. The volume of each sump is $-7500 \mathrm{~L}$ (2000 gal.). Any water that accumulates in the underpad gravel base drains underlying the pads is routed to the monitoring station and collected in a $-3800-\mathrm{L}(1000$ gal.) sump.

Samples of pad runoff are collected using electronically controlled automatic samplers. Each sample is analyzed for gross alpha, gross beta, and gamma activity. Samples are also periodically analyzed for ${ }^{3} \mathrm{H}$ activity.

Pad runoff water $\mathrm{pH}$ is continuously monitored using $\mathrm{pH}$ probes in both the stormwater and infiltration sumps. These data are recorded electronically by a data acquisition system. A signal is sent to open solenoid valves in the $\mathrm{CO}_{2}$ lines if the $\mathrm{pH}$ in pad runoff water rises above 8.5. This allows flow of $\mathrm{CO}_{2}$ into the runoff water, thus lowering the $\mathrm{pH}$. The system has worked well to maintain effluent $\mathrm{pH}$ levels below the NPDES limit. 
To date, little water has drained from the underpad even during periods of heavy rainfall. Thus, the upgradient French drain is functioning effectively to route shallow groundwater around the facility. The valve controlling flow from the underpad discharge line into the underpad sump remains closed during normal operations. When the site is visited to collect pad runoff samples, this valve is opened to check for underpad drainage. If sufficient water for analysis should drain from this line, samples will be collected and analyzed for gross radionuclide activity.

\subsubsection{Results}

Radiological activity present in samples collected at IWMF and elsewhere in SWSA 6 are compared to 'Internal Reporting Levels (IRLs)' which are identical to the 'action levels' developed by Ashwood and Ashwood (1991). The ASEMP-established IRLs for samples collected in SWSA 6 are as follows:

Internal Reporting Levels (IRLs) for samples collected in SWSA 6.

\begin{tabular}{cc}
\hline Analyte & IRL (Bq/L) \\
\hline gross $\alpha$ & 1.0 \\
gross $\beta^{a}$ & 5.0 \\
${ }^{60} \mathrm{Co}$ & 1.5 \\
${ }^{137} \mathrm{Cs}$ & 2.5 \\
${ }^{40} \mathrm{~K}$ & none \\
${ }^{3} \mathrm{H}$ & none \\
\hline
\end{tabular}

aross $\beta$ activity does not include tritium.

Table B.1, Appendix B, tabulates the gross radionuclide results for all samples collected from the IWMF pad runoff collection sumps and the IWMF French drain during FY 1997. Forty samples were collected from the stormwater sump, forty-three from the infiltration sump, and five from the French drain outfall. 
Figures A.4 through A.15, Appendix A, graphically summarize the FY 1997 radiological data for runoff to the stormwater and infiltration sumps. These data show that no samples exceeded the IRLs for gross alpha, gross beta, ${ }^{60} \mathrm{Co}$, or ${ }^{137} \mathrm{Cs}$ activity. No IRL has been established for ${ }^{3} \mathrm{H}$ or ${ }^{40} \mathrm{~K}$ activity in pad runoff. However, ${ }^{3} \mathrm{H}$ activity observed in pad runoff water remains within normal background levels observed in uncontaminated areas of SWSA 6 . Potassium- 40 activity is believed to be the result of leaching of potassium from the concrete. Such leaching contributes gross beta activity from ${ }^{40} \mathrm{~K}$ to the pad runoff water and is believed to be the main contributor to the gross beta activity observed in runoff water from both pads. Error bars displayed on the graphs depict counting errors only $( \pm 1 \sigma)$. If no error bars are shown, the data point represents the minimum detectable amount (MDA) for that analyte. Analytical Services Organization (ASO) reports error ranges regardless of the MDA. Instrumentation used in ESD for gamma counting reports only the MDA if the activity is less than or equal to the MDA. ASO performs the gross alpha and beta counts while ESD performs the gamma counting of ASEMP samples.

Gross alpha activity in water sampled from both sumps is generally at or only slightly above nondetectable levels (Figs. A.4 and A.5, Appendix A). The highest observed level of gross alpha activity in the stormwater sump was $0.15 \mathrm{~Bq} / \mathrm{L}$. The highest observed gross alpha activity in the infiltration sump was $-0.3 \mathrm{~Bq} / \mathrm{L}$ (although this value is associated with a relatively large error bar). Gross beta activity in pad runoff water entering the stormwater sump (Fig. A.6, Appendix A) averaged $0.38 \mathrm{~Bq} / \mathrm{L}$ for the year. Average beta activity for the infiltration sump samples (Fig. A.7, Appendix A) was $0.89 \mathrm{~Bq} / \mathrm{L}$, more than twice that of stormwater sump samples. Both averages were similar to the observed average values for FY 96, with the stormwater runoff average beta activity decreasing slightly and the infiltration runoff average beta activity remaining almost identical to last year. Maximum observed values of gross beat activity were $3.14 \mathrm{~Bq} / \mathrm{L}$ and $0.78 \mathrm{~Bq} / \mathrm{L}$ for infiltration sump and stormwater sump samples, respectively. All beta activity measurements were well below the IRL of $5.0 \mathrm{~Bq} / \mathrm{L}$. Potassium-40 activity (Figs. A.8 and A.9, Appendix A), previously observed in tumulus runoff water in association with elevated levels of gross beta activity (Morrissey et al. 1994a, 1994b; Morrissey and Cunningham 1996, 1997), was infrequently detected above the MDA (typically 2 to $4 \mathrm{~Bq} / \mathrm{L}$ ) in stormwater or infiltration sump samples. The ${ }^{40} \mathrm{~K}$ activity is suspected to be the result of potassium leaching from the concrete vaults and pads and is assumed to account for the observed gross beta activity; however, the trace levels of ${ }^{40} \mathrm{~K}$ activity observed prevents a direct correlation between gross beta activity and ${ }^{40} \mathrm{~K}$ activity in IWMF pad water runoff samples. No pad runoff samples exceeded the ${ }^{60} \mathrm{Co}$ or ${ }^{137} \mathrm{Cs}$ IRLs of $1.5 \mathrm{~Bq} / \mathrm{L}$ and $2.5 \mathrm{~Bq} / \mathrm{L}$, respectively (Figs. A.10 through A.13, Appendix A). Most ${ }^{50} \mathrm{Co}$ or ${ }^{137} \mathrm{Cs}$ data were at or below minimum detectable amounts. Tritium activity in runoff water in both sumps (Figs. A.14 and A.15, Appendix $A$ ) remained within normal background levels for uncontaminated areas of 
SWSA 6.

Analysis of samples collected from the IWMF French drain outfall (Table B.1, Appendix $B$ ) indicate only trace levels of radiological activity with no exceedances of any SWSA 6 IRL. Only traces of water drained from the IWMF underpad system even after periods of heavy rainfall. Therefore, no samples were collected. The absence of water in the underpad indicated that the French drain was performing as designed to route shallow groundwater away from the IWMF underpad system.

\subsection{2 $\mathrm{pH}$ control of pad water runoff}

\subsubsection{Methodology}

In response to elevated $\mathrm{pH}$ in pad runoff water caused by the contact of unbuffered rain water with the concrete pads, an automatic, $\mathrm{CO}_{2}$-based $\mathrm{pH}$ control system was installed at IWMF. The system consists of a pH probe in both the infiltration and the stormwater sumps, a pressure transducer calibrated to measure water level in the stormwater sump, a supply of $\mathrm{CO}_{2}$, two solenoid valves, and an electronic data acquisition device with input and output controls. Carbon dioxide can be released into either sump in response to elevated $\mathrm{pH}$ as long as the pressure transducer records a water level indicating flow from the pads. The flow rate of runoff leaving the pads is restricted by adjusting the opening of the sump outflow valves and by a 3-in. high stainless steel plate at the outlet base of each sump. This plate allows $\sim 3$ in. of water to remain in the sumps at all times. Controller set points are such that if the level in the stormwater sump is $>3.2 \mathrm{in}$. and the $\mathrm{pH}$ in either sump is $>8.5$, the appropriate solenoid valve in the $\mathrm{CO}_{2}$ line is opened by an electronic signal from the data logger and gas flows into the sump. If either the water level or the $\mathrm{pH}$ fall below set points, the data logger signal closes the solenoid valve and gas flow ceases. The data logger reads $\mathrm{pH}$ and water level once a minute and records data every $15 \mathrm{~min}$. as an average of the 1-min. values.

\subsubsection{Results}

Figures A.16 through A.27, Appendix A, display a record of the average 15-min. $\mathrm{pH}$ changes recorded at the IWMF outfall, in the stormwater sump, and in the infiltration sump. These figures display $\mathrm{pH}$ data for each quarter of FY 1997 at each location. Data for the fourth quarter are incomplete due to repairs to the $\mathrm{pH}$ control system and to general maintenance activities at the IWMF monitoring area. The data show that IWMF outfall pH (Figs. A.16, A.19, A.22, and A.25, Appendix A) exceeded the NPDES permit limit for only one very brief period during the fourth quarter (Fig. A.25, Appendix A). Average, maximum, and minimum $\mathrm{pH}$ values observed were: 


\begin{tabular}{ccccc} 
Location & Quarter & Average $\mathbf{p H}$ & Maximum pH & Minimum pH \\
\hline Outfall & first & 7.63 & 8.31 & 7.63 \\
& second & 7.43 & 8.39 & 6.78 \\
& third & 7.21 & 8.69 & 6.39 \\
& fourth & 7.99 & 8.78 & 7.08 \\
Stormwater sump & first & 8.02 & 9.04 & 7.25 \\
& second & 7.62 & 8.86 & 6.69 \\
& third & 6.88 & 8.47 & 5.91 \\
& fourth & 6.62 & 7.34 & 6.17 \\
Infiltration sump & first & 7.75 & 8.97 & 6.24 \\
& second & 7.31 & 8.73 & 5.55 \\
& third & 7.56 & 8.74 & 6.00 \\
& fourth & 8.00 & 9.10 & 7.26 \\
\hline
\end{tabular}

\subsubsection{Soil sampling}

\subsubsection{Methodology}

Surface soil was collected at ten locations behind and to the sides of the IWMF facility by the method described in procedure ASEMP-04. The gravel pad precludes soil sampling in front of the facility. The purpose of collecting such samples is to monitor for radiological contamination in the IWMF area that may be caused by IWMF loading operations.

\subsubsection{Results}

Results of the FY 1997 soil sampling at the IWMF area are presented in Table B.2, Appendix $B$. All radiological data are within normal background levels typically observed in uncontaminated areas of SWSA 6 and similar to results obtained from previous sampling rounds. These results confirm that IWMF loading operations are not causing soil contamination where soil samples are obtainable in the immediate vicinity of the IWMF storage pads.

\subsection{HILLCUT DISPOSAL TEST FACILITY}


The HDTF is a demonstration project that was initiated in 1981 but discontinued the following year before any wastes were emplaced (see Figs. A.1 and A.2, Appendix A, for location in SWSA 6). In 1985, the project was reactivated as part of the Low-Level Waste Disposal Development and Demonstration project. The HDTF provided a method for disposing of high-activity LLW since no suitable greater-confinement burial method was available at the time. The HDTF demonstration also provided a means by which to evaluate the use of hillslope cuts as possible sites for future engineered disposal facilities. The objective of the demonstration was to assess the degree of hydrologic isolation afforded by this type of design. Currently, the only activity at HDTF is collecting, measuring, and analyzing runoff water from the pad and underpad areas.

Figure A.28, Appendix A, is an aerial view of the HDTF area showing the location of the buried vaults, drain lines, drain tanks, and storage tanks. Figure A.29, Appendix $A$, shows the design of the HDTF with its monitoring wells and gravity drain. The HDTF is similar to the tumulus-type facilities and consists of a concrete pad $(4.6 \mathrm{~m} \times 4.6 \mathrm{~m})$ constructed in a cut from the side slope of a hill. The pad was installed above the expected high water table in the area. Twenty-seven concrete boxes $(1.1 \mathrm{~m} \times 1.1 \mathrm{~m} \times$ $1.4 \mathrm{~m}$ ) of high-activity LLW were placed on the pad and covered with soil. The lids of the boxes were sealed with a bitumen mastic, and the boxes were banded. A runoff collection system was installed to drain both the pad and the gravel area beneath the pad. The HDTF allows for runoff from the pad and the gravel drain to be collected separately in two above-grade 500-gal tanks downslope from the facility (under the covered area in Fig. A.28; Appendix A). The three 500-gal storage tanks visible in Fig. A.28 provide for storage of runoff water drained from the runoff collection (holding) tanks. Sampling ports are provided in the drain lines between the holding tanks and the storage tanks.

Water can reach the buried waste vaults through infiltrating precipitation or shallow stormflow. Infiltrating precipitation is routed from the surface of the buried pad to the pad holding tank. If the water table rises following heavy rains, the gravel base below the pad intercepts water from the shallow aquifer and drains it away from the pad to the underpad holding tank. 


\subsubsection{Pad and underpad runoff collection and analysis}

\subsubsection{Methodology}

The HDTF design allows water that drains from the pad surface and the underpad to be collected in separate tanks at the outfall. When water in these tanks reaches $-70 \%$ of tank capacity, each is drained to storage tanks, sampled, and analyzed for gross radionuclide parameters. The storage tanks are eventually emptied and transported to the Process Waste Treatment Plant (PWTP). Transport to the PWTP is necessary since the HDTF is a RCRA facility due to the presence of lead in some of the wastecontaining vaults.

Samples are analyzed for gross alpha, gross beta, and gamma activity. When the analytical results are received, the SWSA 6 foreman is notified of the results. The foreman is responsible for transporting the collected water to the PWTP. If radioactivity levels are above the IRLs, the ASEMP program manager is notified.

\subsubsection{Results}

Most of the collected water drains from the surface of the pad. About 3500 gal was collected from the pad surface while $\sim 1500 \mathrm{gal}$ was collected from the underpad drainage system. Table B.3, Appendix B, summarizes the FY 1997 HDTF data. Ten samples of pad surface water and five samples of underpad water were analyzed. All radiological data were below SWSA 6 IRLs. A low level of gross beta activity was observed in all samples (average $0.69 \mathrm{~Bq} / \mathrm{L}$ for pad surface water and $0.34 \mathrm{~Bq} / \mathrm{L}$ for underpad water). The slightly higher beta activity observed in the pad surface water is likely the result of potassium leaching from the concrete pad, similar to the postulated mechanism for the beta activity observed in IWMF pad runoff.

\subsection{CONCLUSIONS}

Data continue to show that the IWMF is effectively containing the vaulted waste. Pad runoff water data demonstrate that no leakage of waste from the vaults was detected. No pad-water samples exceeded the IRLs for gross alpha, gross beta, ${ }^{137} \mathrm{Cs}$, or ${ }^{60} \mathrm{Co}$ activity. Tritium activity in pad runoff samples remains at background levels. Only a low-level of gross beta activity was observed. This beta activity is postulated to be a result of potassium $\left({ }^{40} \mathrm{~K}\right)$ leaching from the concrete. Beta activity in the infiltration sump water averaged more than twice that of stormwater sump samples. The greater mass of concrete on the fully loaded pads that drain to the infiltration sump is presumed to account for this observed difference in beta activity. 
The absence of water in the underpad drainage system confirms that the IWMF French drain continues to perform its intended purpose of suppressing the water table beneath the pads.

The IWMF $\mathrm{CO}_{2}$-based pH control system continued to function well. However, runoff water $\mathrm{pH}$ remained below 9 most of the time; thus, the $\mathrm{pH}$ control system was seldom challenged. Only one very brief period of outfall pH above the NPDES permit limit of 9.0 was observed in FY 1997.

Water continues to drain from the HDTF during the wet season. Approximately $5000 \mathrm{gal}$ of combined pad and underpad drainage was collected and sampled during FY 1997. All radiological measurements were below SWSA 6 IRLs.

\section{TRANSURANIC WASTE FACILITIES IN SWSA 5 NORTH}

Active TRU waste management facilities in SWSA $5 \mathrm{~N}$ include above ground buildings, buildings that are below ground on three sides, and auger holes similar to the highrange wells in SWSA 6. Prior to DOE Order 5820.2A, TRU wastes were also emplaced in unlined trenches in SWSA $5 \mathrm{~N}$. Within the trenches, TRU wastes were placed in concrete casks and wooden and metal boxes (Stewart et al. 1989). The shallow aquifer extends above the bottom of the trenches during high water table conditions (Wickliff et al. 1991b). Transuranic isotopes, presumably leaching from wastes in the trenches, were first measured in a downgradient well by Ashwood and coworkers (Ashwood et al. 1990). Subsequently, transuranic isotopes were detected in seeps along the bank of White Oak Creek (Ashwood et al. 1991a). Thus, transport from the trenches is known to occur through the shallow aquifer along discrete subsurface pathways.

\subsection{METHODOLOGY}

Samples were collected monthly from the eight sumps that drain various SWSA $5 \mathrm{~N}$ waste storage areas. Samples were obtained simply by lowering dedicated sample bottles below the water level in the sump, retrieving, and transferring to clean bottles appropriately labeled for the required analyses. Samples were analyzed for gross alpha, gross beta, and gamma activity. Internal reporting limits for gross alpha and gross beta activity in water collected from these sumps are set at 10 and $20 \mathrm{~Bq} / \mathrm{L}$, respectively. The SWSA $5 \mathrm{~N}$ foreman is responsible for pumping water from the sumps and transporting to the PWTP after being notified of the collection of samples by ASEMP. 
Fifteen groundwater wells surrounding the TRU-waste storage facilities were sampled. Samples were collected by slowly pumping from the wells with a peristaltic pump until the conductivity, $\mathrm{pH}$, and dissolved oxygen values stabilized. All samples were filtered through $0.45-\mu \mathrm{m}$ filters and then acidified to a $\mathrm{pH}<2$ with nitric acid. Analytes include gross alpha, gross beta, gamma activity $\left({ }^{60} \mathrm{Co},{ }^{137} \mathrm{Cs}\right),{ }^{241} \mathrm{Am},{ }^{244} \mathrm{Cm}$, metals, and anions. Internal Reporting Levels have been established for gross beta (2 $\mathrm{Bq} / \mathrm{L}),{ }^{60} \mathrm{Co}\left(1.5 \mathrm{~Bq} / \mathrm{L}\right.$ ), and ${ }^{137} \mathrm{Cs}(1 \mathrm{~Bq} / \mathrm{L}$ ) in SWSA $5 \mathrm{~N}$ groundwater (Ashwood and Ashwood 1991). No IRL was established for gross alpha activity because gross alpha is not a reliable indicator of transuranic contamination at the low levels observed in SWSA 5 North groundwater samples.

\subsection{RESULTS}

\subsubsection{Storage Facility Sumps}

Sumps that drain Buildings 7855,7826 , and 7834 are identified in the aerial photograph of SWSA $5 \mathrm{~N}$ in Appendix A (Figure A.31). Water samples collected monthly from these sumps were analyzed for gross alpha, gross beta, and gamma activity.

Radiological data from the SWSA $5 \mathrm{~N}$ sump samples is presented in Table B.4, Appendix B. All sumps, except 7855 , are free from any radiological activity above the IRLs. All nine samples collected from 7855 showed gross beta activity above the 20 $\mathrm{Bq} / \mathrm{L}$ IRL (average value $-60 \mathrm{~Bq} / \mathrm{L}$ ). However, the observed gross beta activity is consistently associated with elevated ${ }^{40} \mathrm{~K}$ activity (average value $-66 \mathrm{~Bq} / \mathrm{L}$ ). Water collected from this sump is a yellowish-brown color indicating that the water has probably leached organic material from soil and/or decaying vegetation. The presence of ${ }^{40} \mathrm{~K}$ activity provides assurance that the gross beta activity is not the result of any radiological component of the waste but is most likely leached from the same organic material that caused the coloration. Trace levels of ${ }^{137} \mathrm{Cs}$, well below the IRL, are also noted in 7855 .

Traces of gross beta activity are observed in the 7826 sumps. The four 7834 sumps also show low levels of beta activity. In particular, gross beta activity in 7834-3 and 7834-4 ranges from -1 to $4 \mathrm{~Bq} / \mathrm{L}$ and is frequently associated with ${ }^{40} \mathrm{~K}$ activity. Gross alpha activity, in the range of $\sim 0.3$ to $0.7 \mathrm{~Bq} / \mathrm{L}$, is consistently present in sump 7834-4 and is occasionally detected at trace levels in other sumps.

\subsubsection{Groundwater Wells}

Radiological data from the FY 1997 SWSA $5 \mathrm{~N}$ groundwater monitoring wells is presented in Table B.5, Appendix B. Gross alpha activity continued to be present in 
monitoring well 516, immediately downgradient from the TRU waste trenches (Figure A.30, Appendix A). The dominant radionuclide that accounts for the alpha activity in well 516 is ${ }^{244} \mathrm{Cm}$, but traces of ${ }^{241} \mathrm{Am}$ were also detected. Metal concentrations in this well have been below regulatory concern (Ashwood et al. 1991b).

Table B.6, Appendix B, presents radiological data from the SWSA $5 \mathrm{~N}$ seep sampling. Several seeps along the bank of White Oak Creek (WOC) are inspected and sampled if sufficient water is flowing. Well 516 and the TRU waste trenches are upgradient from WOC, which drains most of ORNL and eventually enters the Clinch River. These seeps are along geologic strike with the trenches. Only one seep (258) produced sufficient water for the desired analyses at the time of collection. Seep 258 continued to show the presence of trace quantities of ${ }^{244} \mathrm{Cm}$ and ${ }^{241} \mathrm{Am}$ associated with a very low level of gross alpha activity.

Anion and cation analyses were also conducted for SWSA $5 \mathrm{~N}$ groundwater. These data, presented in Table B.7, Appendix B, are typical for groundwater in the area. No unusual groundwater chemistry was observed.

\subsection{CONCLUSIONS}

Gross beta activity is consistently present in samples of water collected from the sump that drains building 7855 and can be accounted for by the presence of ${ }^{40} \mathrm{~K}$. All other SWSA $5 \mathrm{~N}$ building sumps are free of any significant radiological contamination.

Alpha activity, primarily attributable to ${ }^{244} \mathrm{Cm}$, continued to be detected in well 516. Historical data show that the measured alpha activity is dependent upon some aspect of the local groundwater conditions at the time of sample collection. As suggested in an earlier ASEMP report (Wickliff et al. 1991b), water table elevation may be the most important variable. At higher water table elevations, more waste in the burial trenches is directly exposed to groundwater. If buried waste in contact with the water table is indeed the source of alpha activity, then any remedial action must address either removal of the waste or isolation of the waste from the water table. Simply capping the trenches to eliminate infiltration will not prevent ground water from contacting the buried waste.

Alpha activity detected in a seep along the bank of White Oak Creek provides additional evidence for the direct hydrologic contact along geologic strike from the waste burial trenches in SWSA $5 \mathrm{~N}$ to well 516 and to the creek. 


\section{ACKNOWLEDGMENTS}

We thank Lauren Larsen of ESD for his expert technical assistance in performing the gamma counting and his advice on data interpretation. Jeff Riggs, Roy Freeman, and Danny Sluss of the Instrumentation and Controls Division have consistently supplied excellent guidance and craftsmanship in the design, operation, and maintenance of the electronic monitoring and sampling equipment. Personnel from the Plant and Equipment Division have provided expert craftsmanship when pipe fitting and other repairs have been required. Numerous other Plant and Equipment personnel and WMRAD employees have provided valuable assistance. Their help is gratefully acknowledged. 


\section{REFERENCES}

Ashwood, J. S., and T. L. Ashwood. 1991. Active sites environmental monitoring program: Action levels. ORNL/M-1569. Oak Ridge National Laboratory.

Ashwood, T. L., D. S. Wickliff, C. M. Morrissey, and H. L. Adair. 1990. Active sites monitoring at Oak Ridge National Laboratory. pp. 397 399. In Proceedings of SPECTRUM 90 Nuclear and Hazardous Waste Management International Topical Meeting, September 30-October 4, 1990, Knoxville, Tennessee. American Nuclear Society, La Grange Park, IL.

Ashwood, T. L., D. S. Wickliff, and C. M. Morrissey. 1991a. Active Sites Environmental Monitoring Program: Mid-FY 1991 Report. ORNL/M-1442. Oak Ridge National Laboratory.

Ashwood, T. L., D. S. Wickliff, and C. M. Morrissey. 1991b. Active sites environmental monitoring program: FY 1991 report. ORNL/M-1792. Oak Ridge National Laboratory.

Ashwood, T. L., D. S. Wickliff, and C. M. Morrissey. 1992a. Active sites environmental monitoring program: FY 1991 annual report. ORNLM-1792. Oak Ridge National Laboratory.

Ashwood, T. L., D. S. Wickliff, and C. M. Morrissey. 1992b. Active Sites Environmental Monitoring Program: Program plan, Rev. 1. ORNLM-1793. Oak Ridge National Laboratory.

Department of Energy (DOE). 1988. Radioactive waste management. DOE Order 5820.2A, September 26, 1988. U.S. Department of Energy, Washington, D.C.

Morrissey, C. M., and G. R. Cunningham. 1995. Active sites environmental monitoring program: FY 1994 annual report. ORNL/M-3788. Oak Ridge National Laboratory.

Morrissey, C. M., and G. R. Cunningham. 1996. Active sites environmental monitoring program: FY 1995 annual report. ORNLM-4950. Oak Ridge National Laboratory.

Morrissey, C. M., and G. R. Cunningham. 1997. Active sites environmental monitoring program: FY 1996 annual report. ORNLM-5507. Oak Ridge National Laboratory.

Morrissey, C. M., T. L. Ashwood, D. S. Hicks, and J. D. Marsh. 1994a. Active Sites 
Environmental Monitoring Program: FY 1993 Annual Report. ORNL/M-3327. Oak Ridge National Laboratory, Oak Ridge, Tennessee.

Morrissey, C. M., T. L. Ashwood, and D. S. Hicks. 1994b. Active sites environmental monitoring program: FY 1992 annual report. ORNL/M-3183. Oak Ridge National Laboratory.

Stewart, R. C., L. S. Dickerson, S. F. Joost, and D. C. Osucha. 1989. Remote-handled transuranic solid waste characterization study: Oak Ridge National Laboratory. ORNLTM-11050. Oak Ridge National Laboratory.

Wickliff, D. S., C. M. Morrissey, and T. L. Ashwood. 1991a. Active sites environmental monitoring program: Mid-FY 1990 summary report. ORNLM-1179. Oak Ridge National Laboratory.

Wickliff, D. S., C. M. Morrissey, and T. L. Ashwood. 1991b. Active sites environmental monitoring program: FY 1990 annual report. ORNL/M-1327. Oak Ridge National Laboratory.

Yager, R. E., J. A. Furnari, and P. M. Craig. 1989. Environmental monitoring six-month report for the tumulus disposal demonstration project: Mid-fiscal year 1989.

ORNL/Sub/89-SC924/2. Oak Ridge National Laboratory. 


\section{APPENDIX A FIGURES}





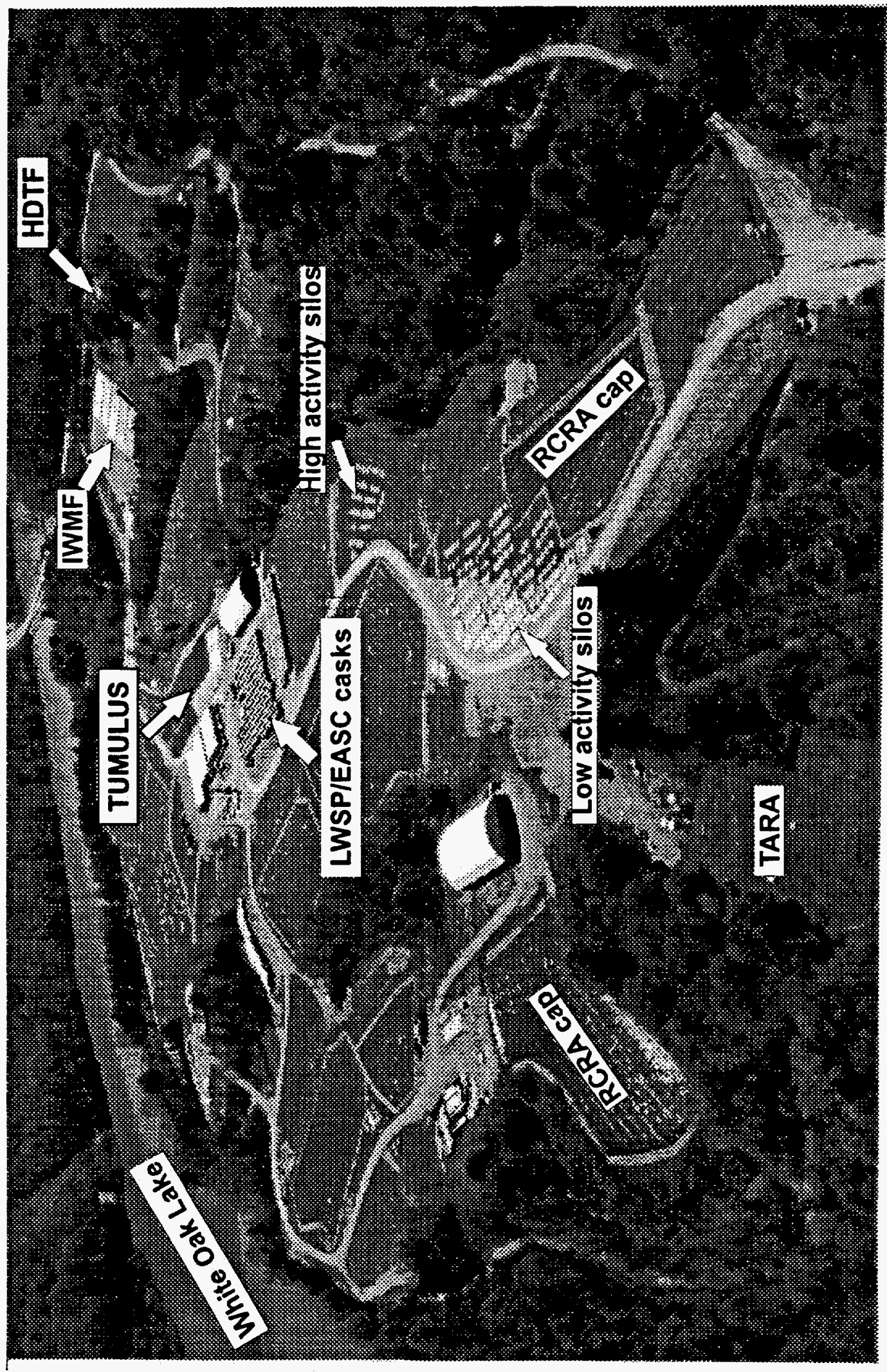

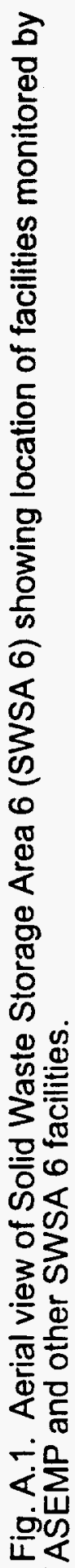




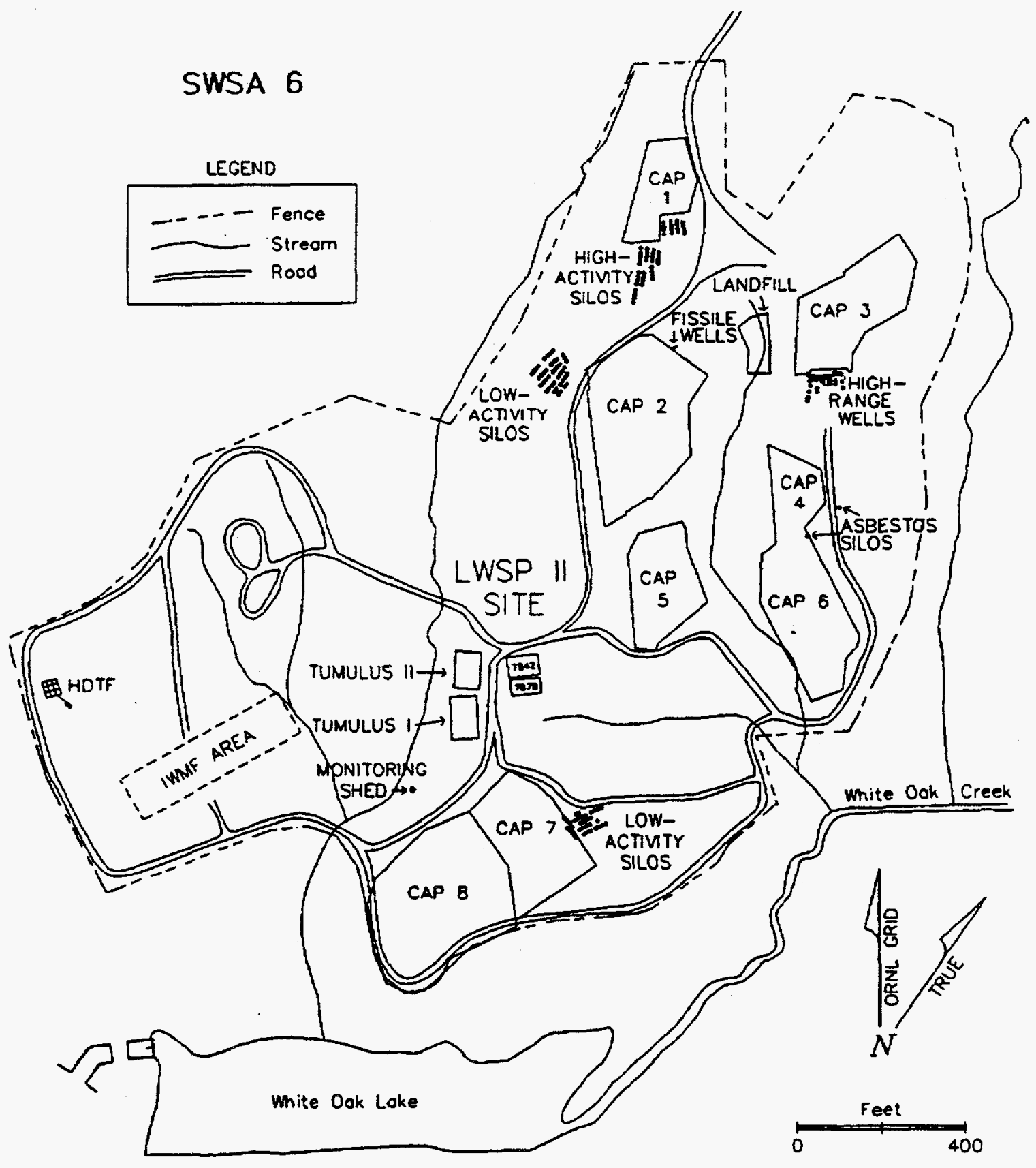

Fig. A.2. Active low-level waste disposal sites and other major facilities in SWSA 6. IWMF and HDTF are monitored under ASEMP. 


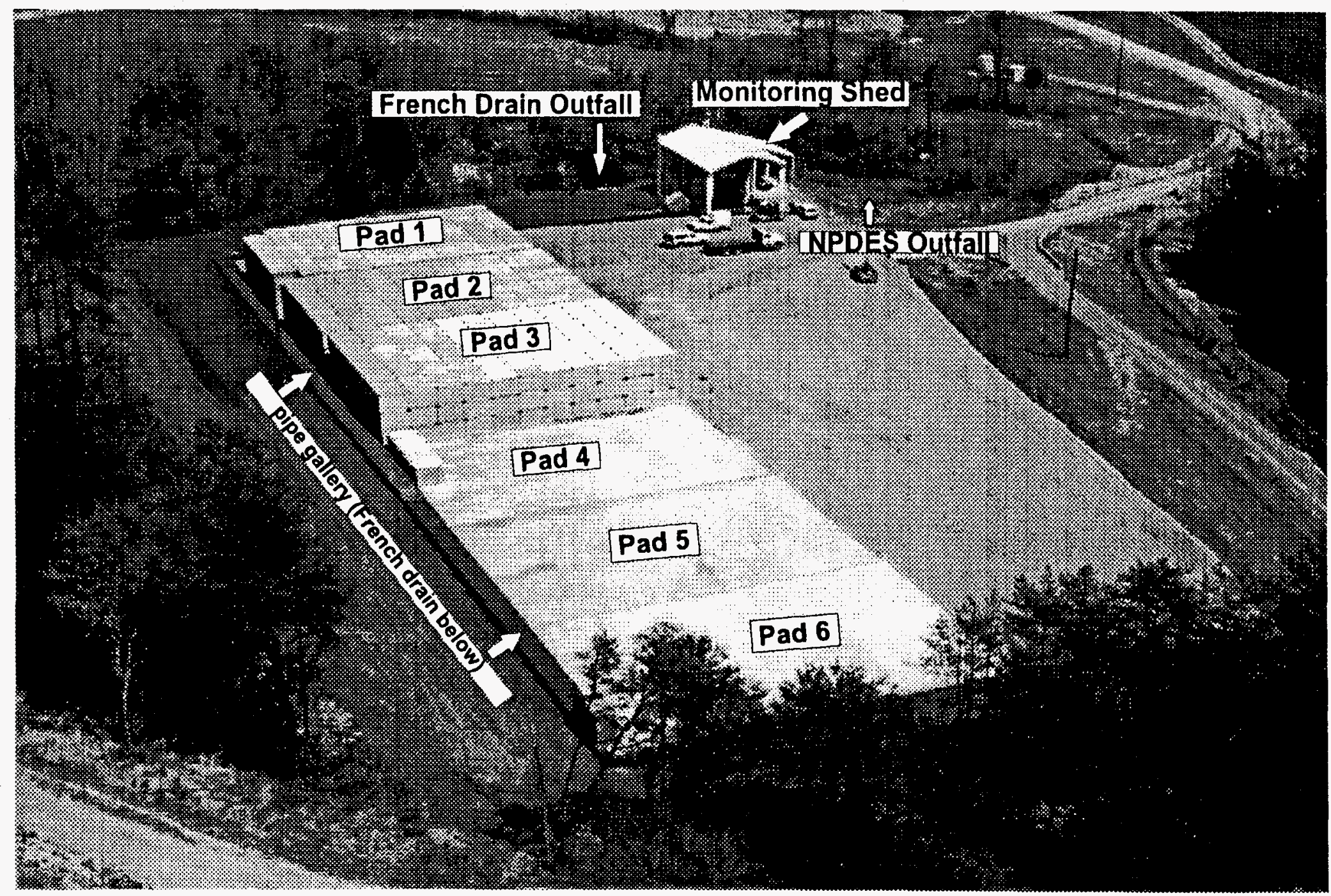

Fig. A.3. Aerial view of the Interim Waste Management Facility (IWMF) showing the six existing concrete pads, monitoring shed, and NPDES and French outfalls. 
A-6

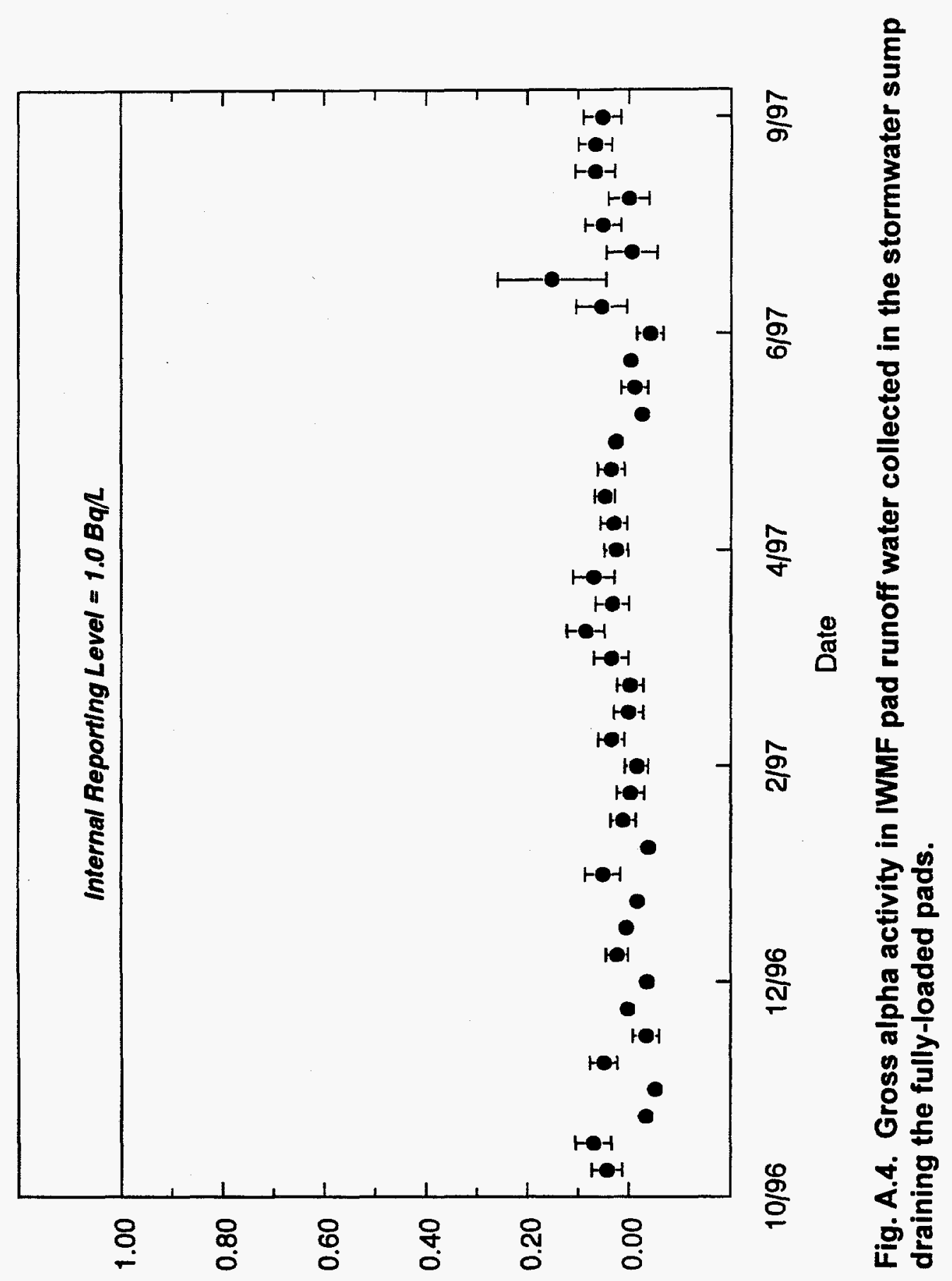

(7/bg) eydje ssos6 


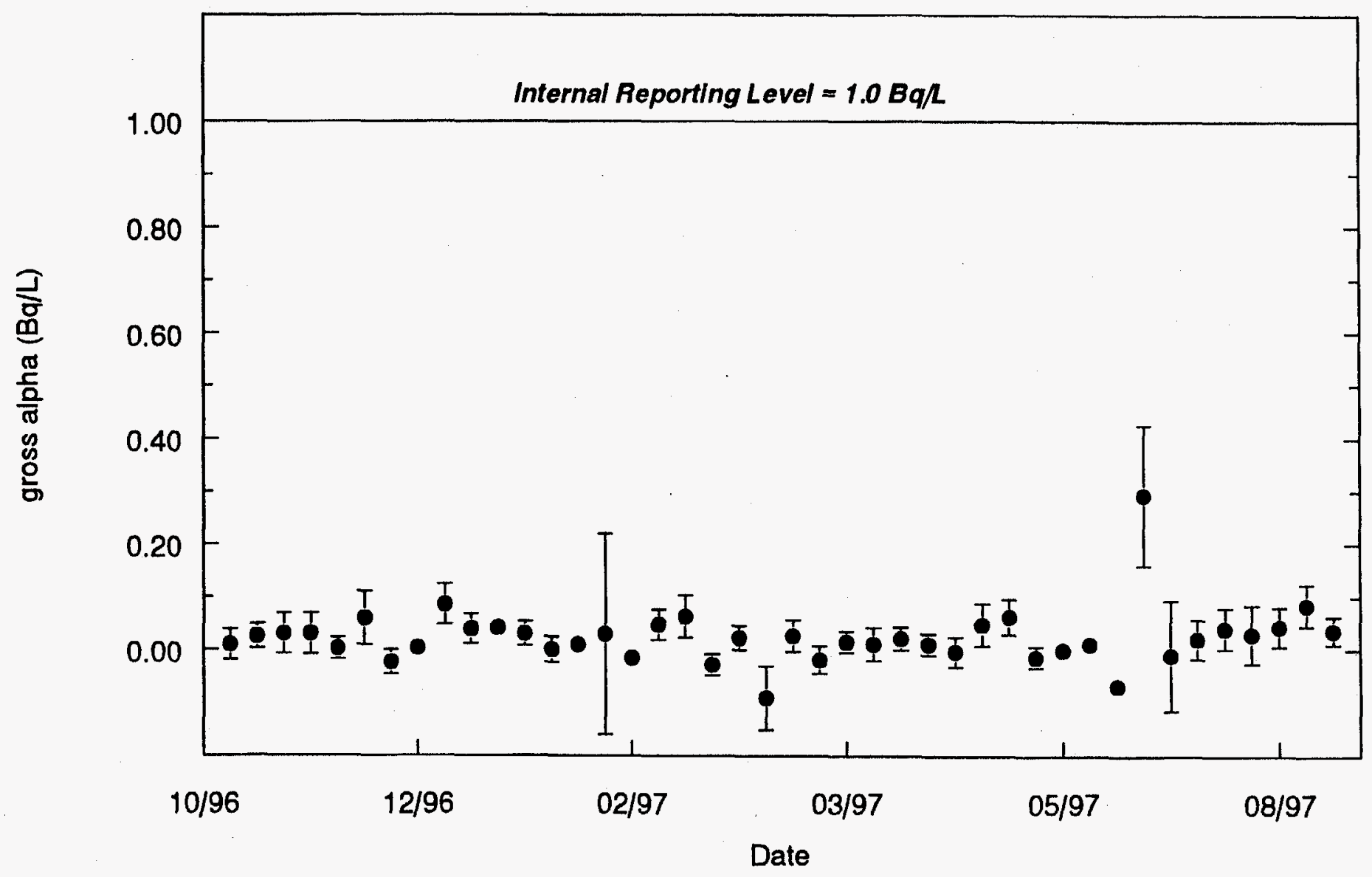

Fig. A.5. Gross alpha activity in IWMF pad runoff water collected in the infiltration sump draining the pads actively being loaded with waste and the empty pads. 


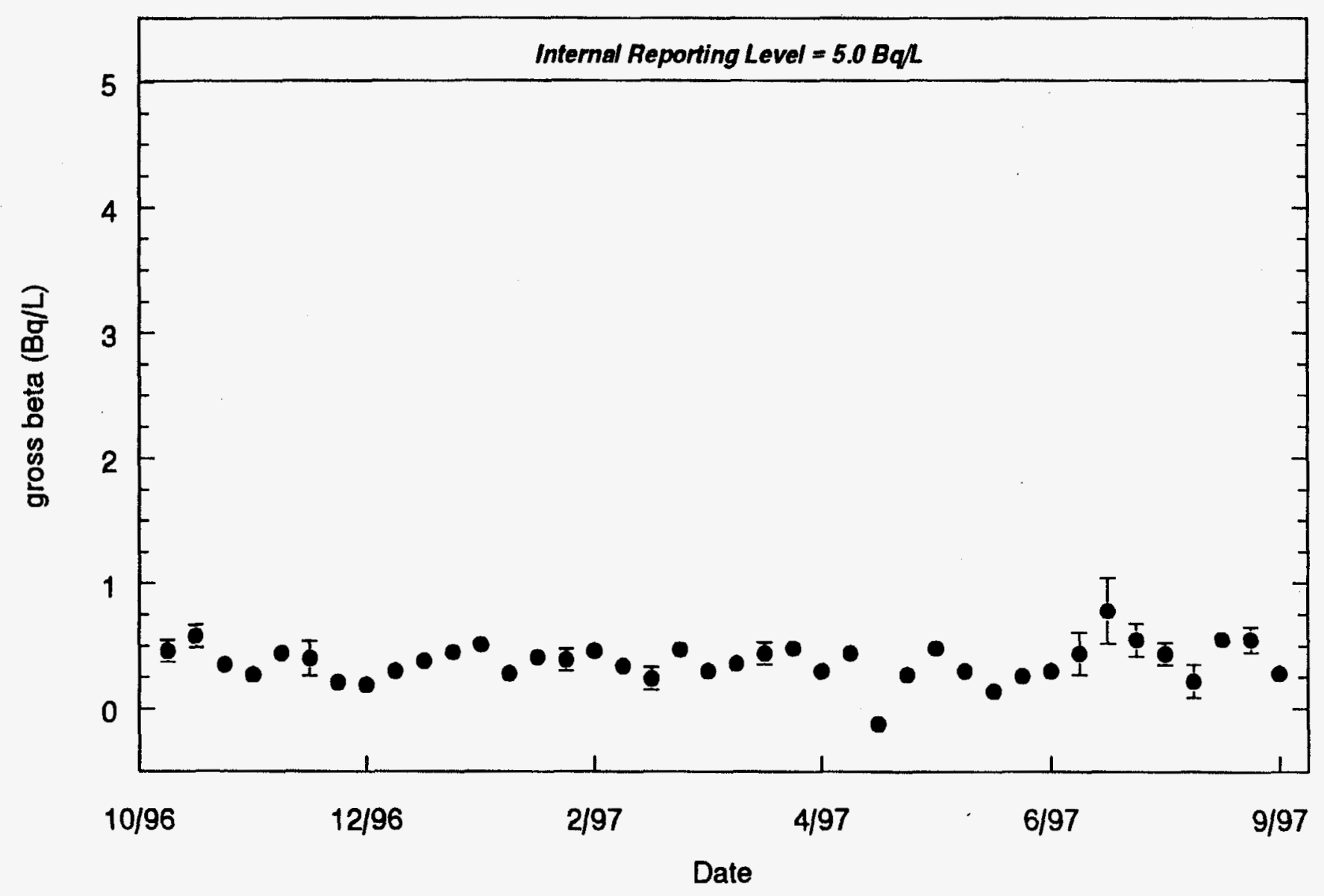

$\underset{\infty}{D}$

Fig. A.6. Gross beta activity in IWMF pad runoff water collected in the stormwater sump draining the fully-loaded pads. 


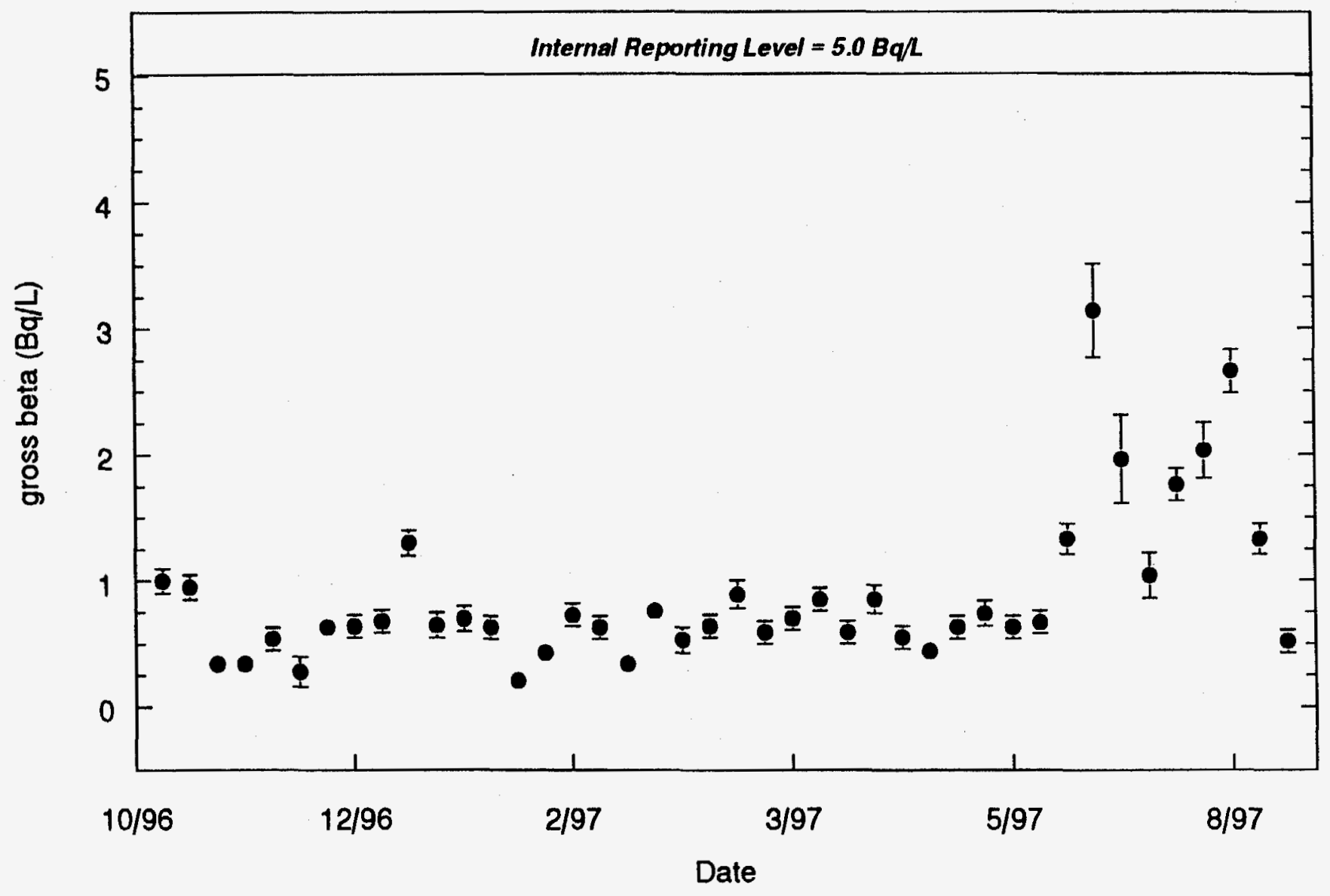

$\frac{7}{6}$

Fig. A.7. Gross beta activity in IWMF pad runoff water collected in the infiltration sump draining the pads actively being loaded with waste and the empty pads. 


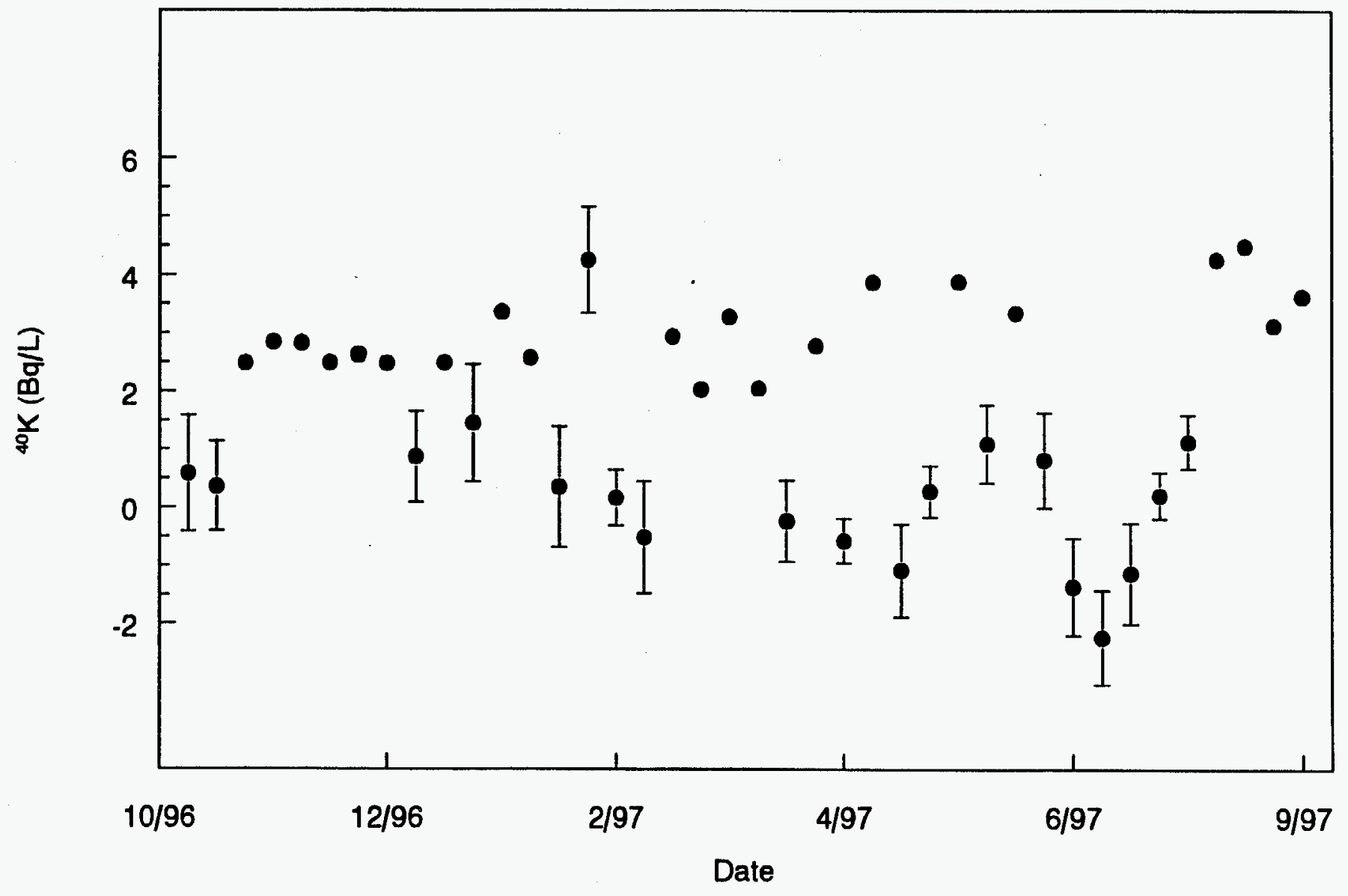

$\frac{1}{0}$

Fig. A.8. Potassium-40 gamma activity in IWMF pad runoff water collected in the stormwater sump draining the fully-loaded pads. 


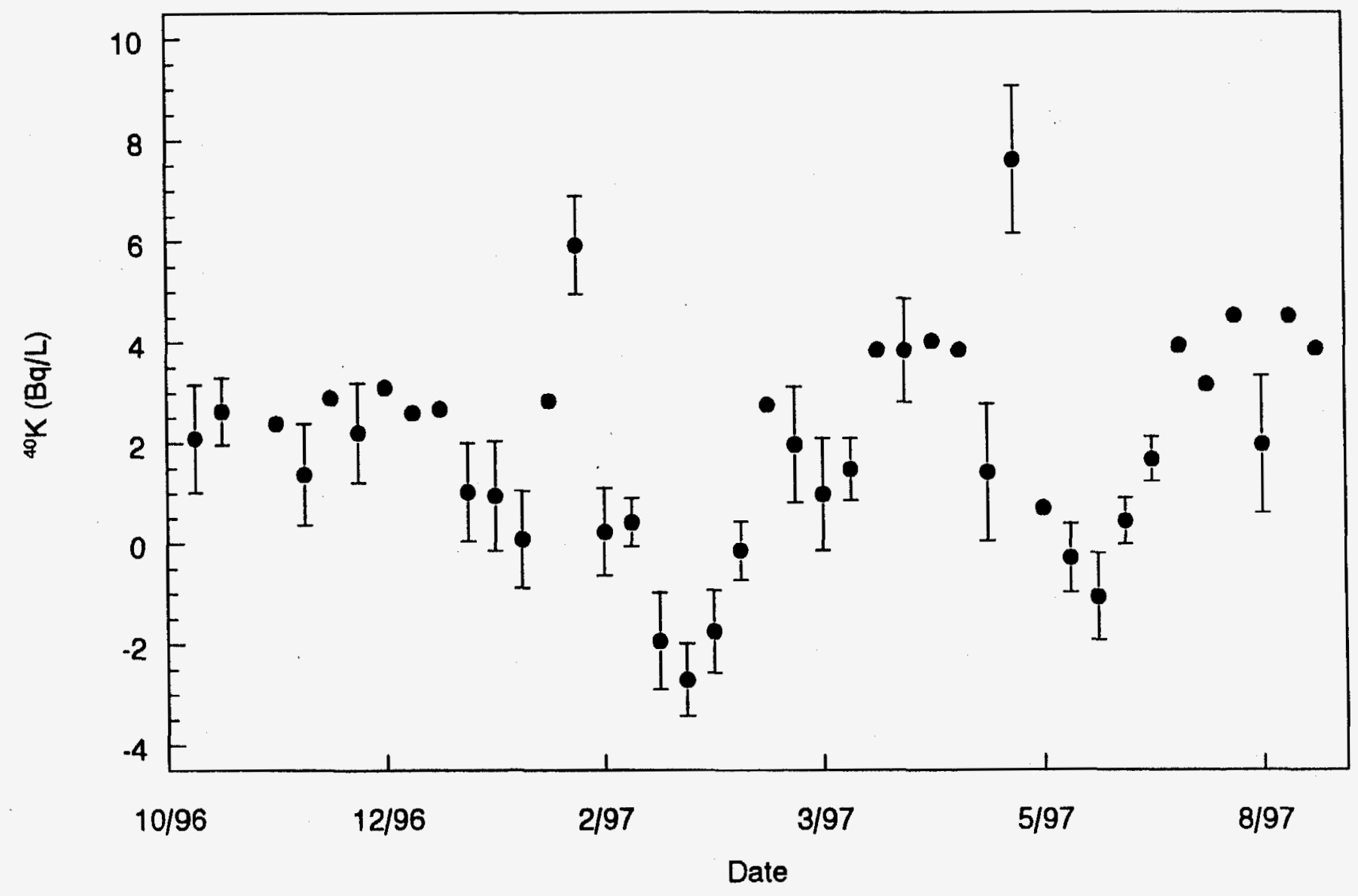

$\stackrel{?}{\vdots}$

Fig. A.9. Potassium-40 gamma activity in IWMF pad runoff water collected in the infiltration sump draining the pads actively being loaded with waste and the empty pads. 


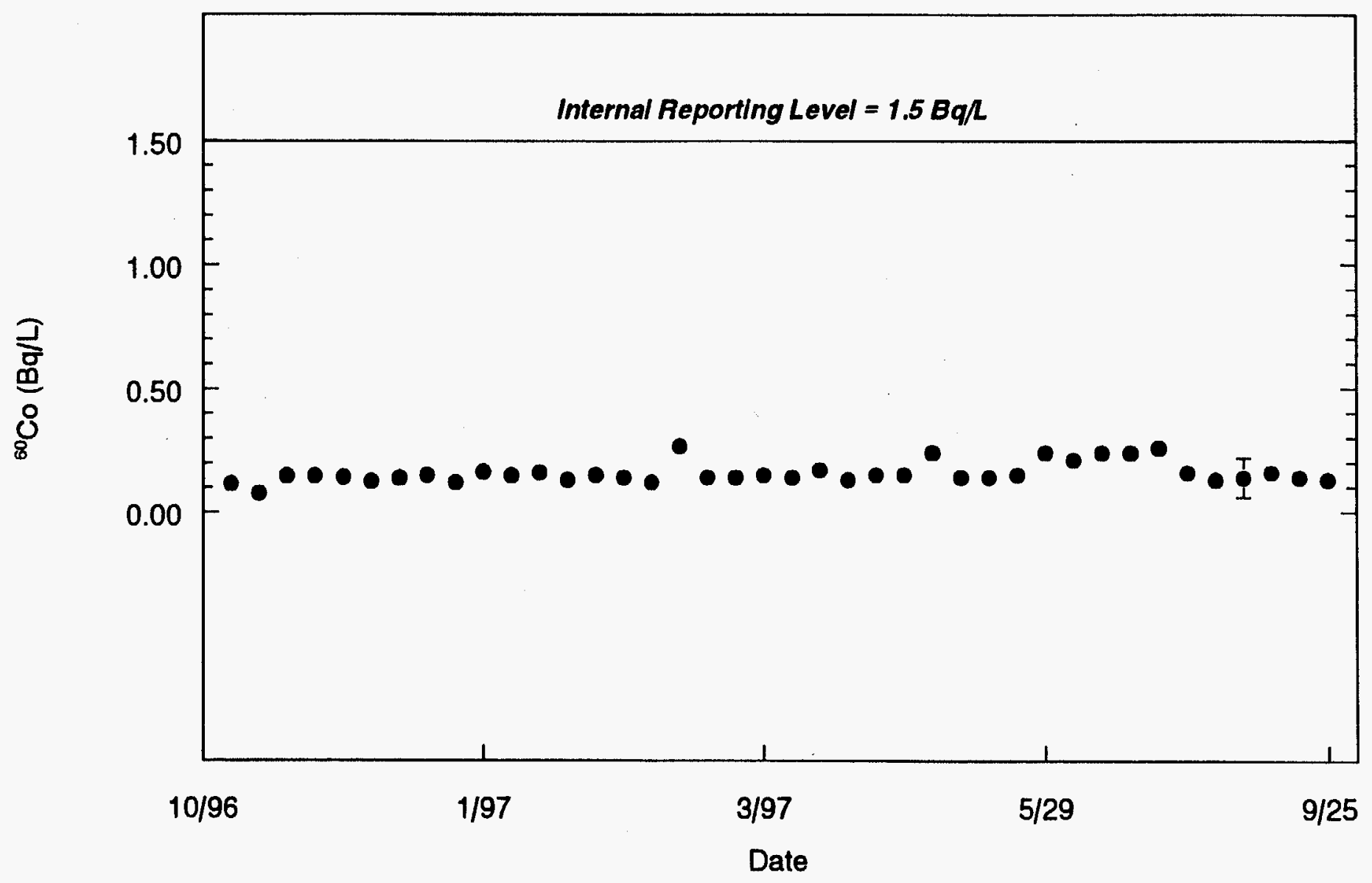

$\frac{2}{N}$

Fig. A.10. Cobalt-60 activity in IWMF pad runoff water collected in the stormwater sump draining the fully-loaded pads. 


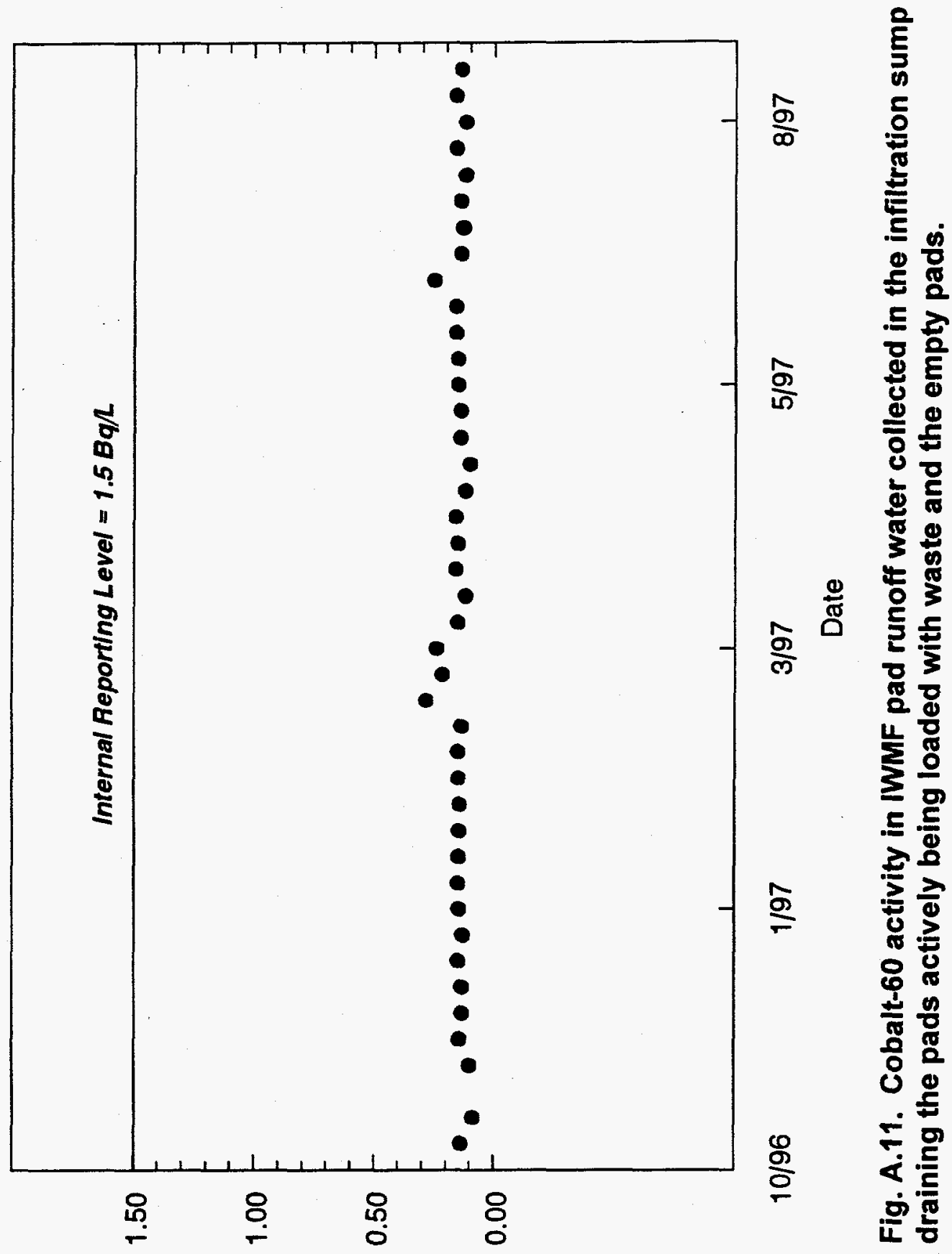

$(7 / \mathrm{bg}) \circ \bigcirc_{09}$ 


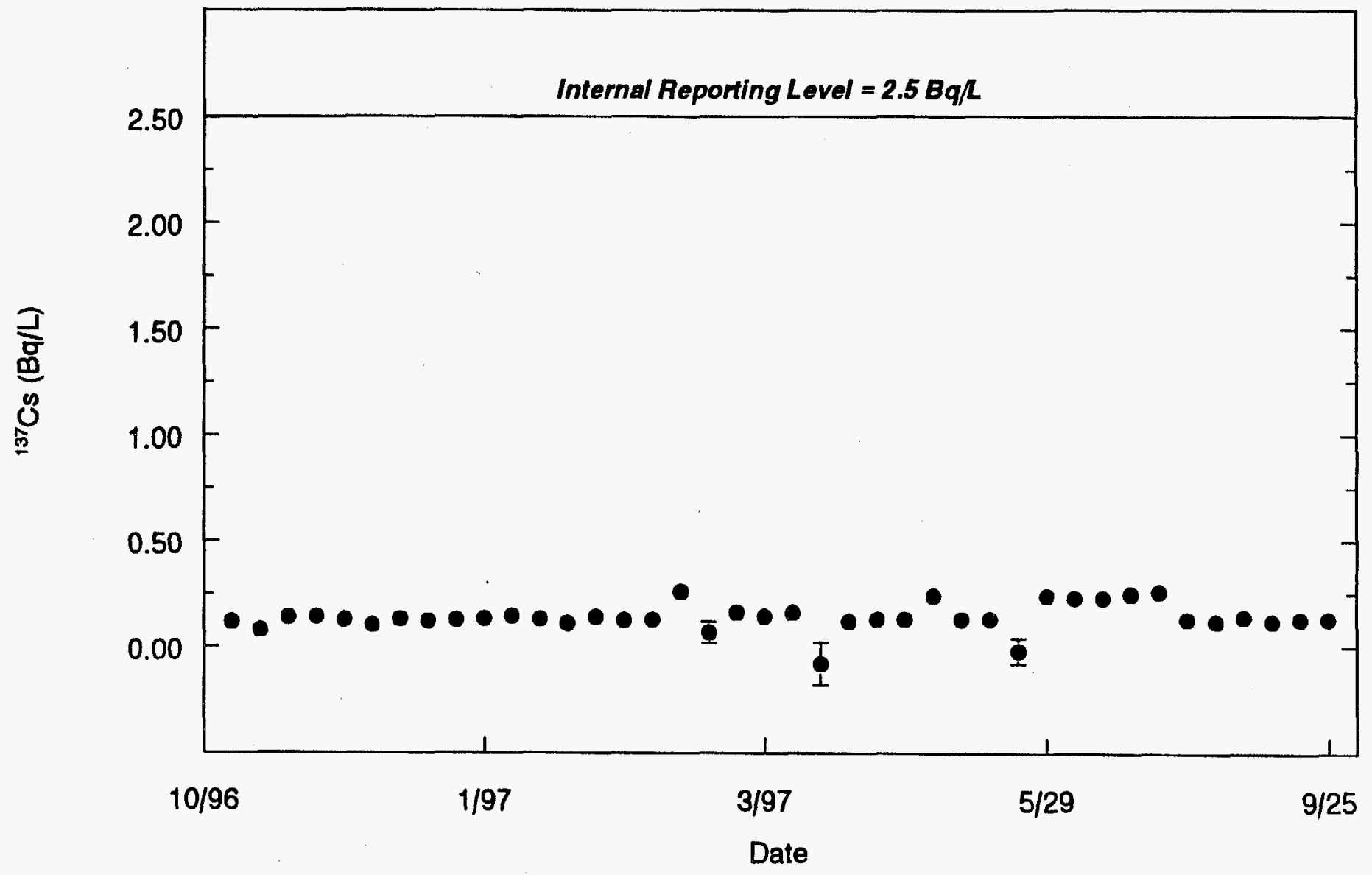

$\frac{1}{1}$

Fig. A.12. Cesium-137 gamma activity in IWMF pad runoff water collected in the stormwater sump draining the fully-loaded pads. 


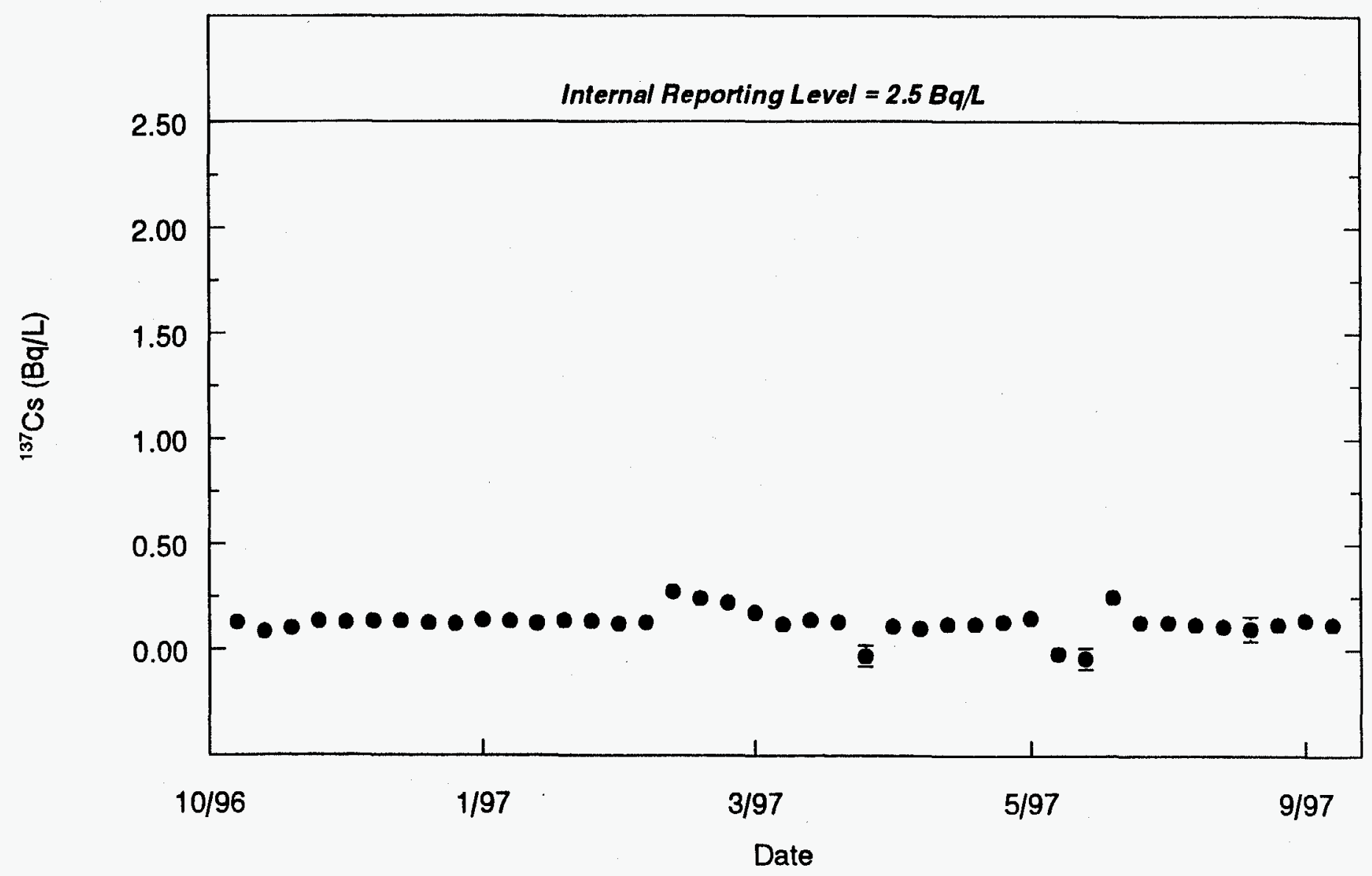

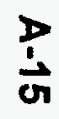

Fig. A.13. Cesium-137 gamma activity in IWMF pad runoff water collected in the infiltration sump draining the pads actively being loaded with waste and the empty pads. 


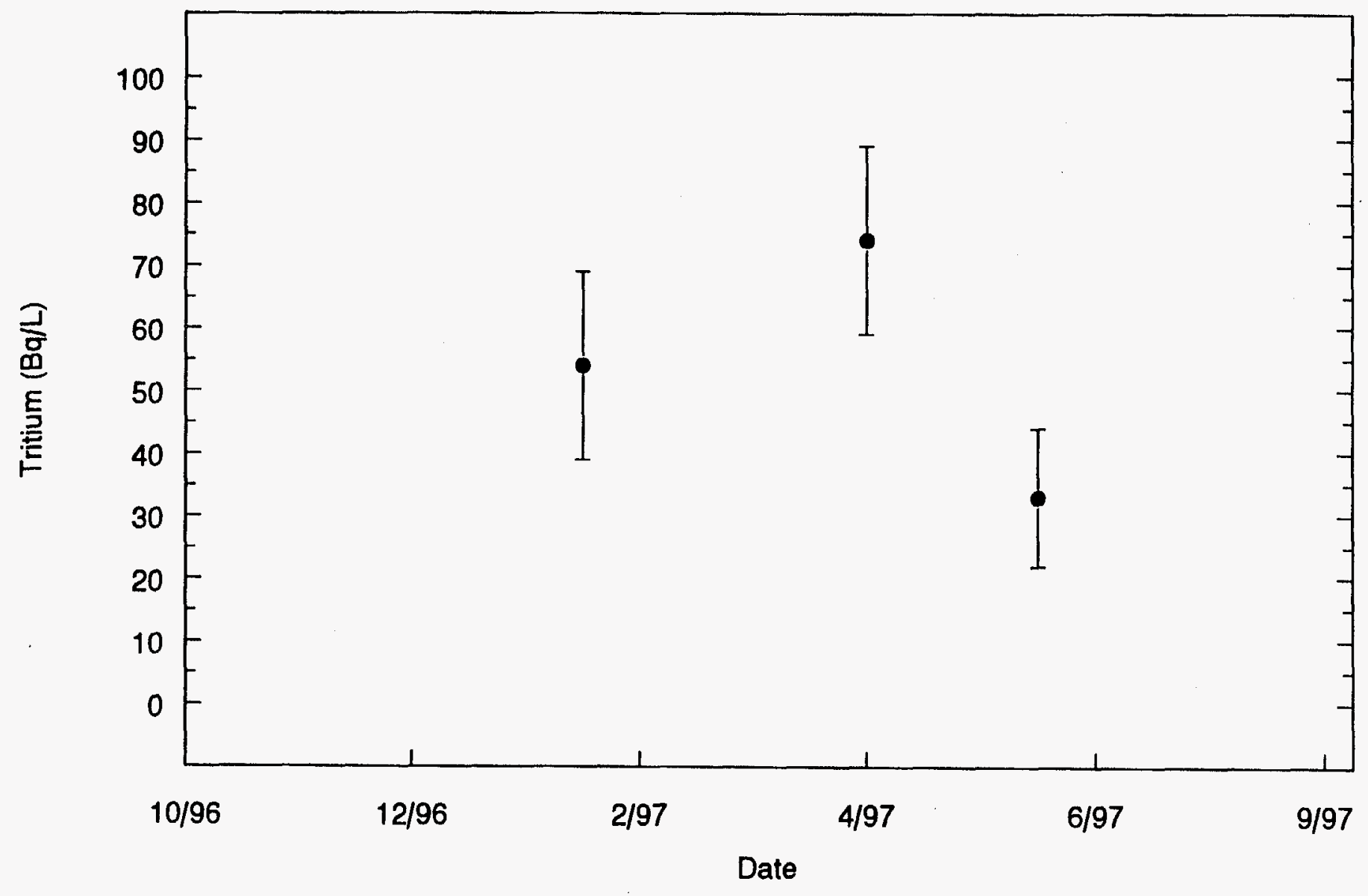

क)

Fig. A.14. Tritium activity in IWMF pad runoff water collected in the stormwater sump draining the fully-loaded pads. 


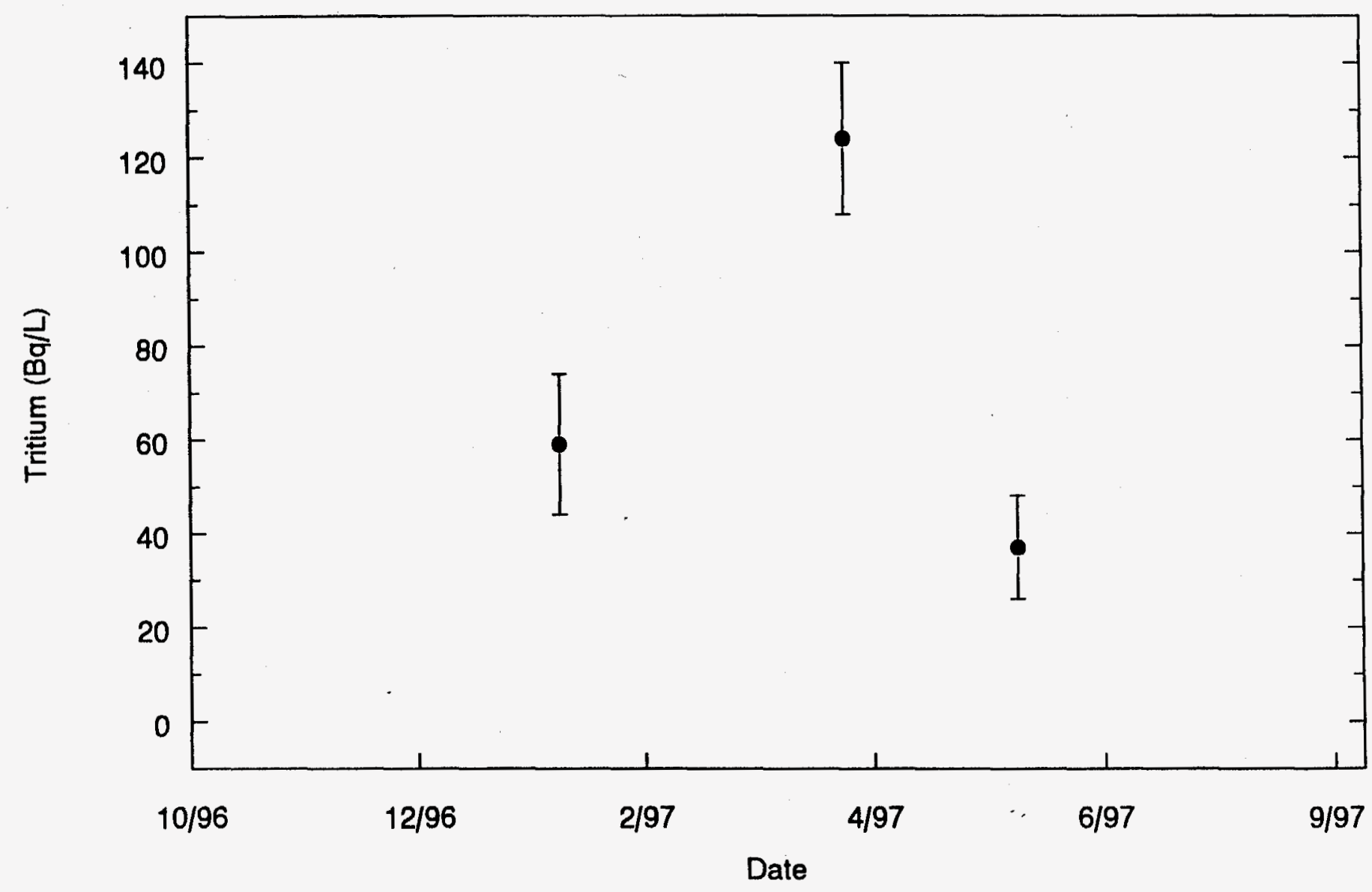

$\stackrel{2}{\overrightarrow{2}}$

Fig. A.15. Tritium activity in IWMF pad runoff water collected in the infiltration sump draining the pads actively being loaded with waste and the empty pads. 
A-18

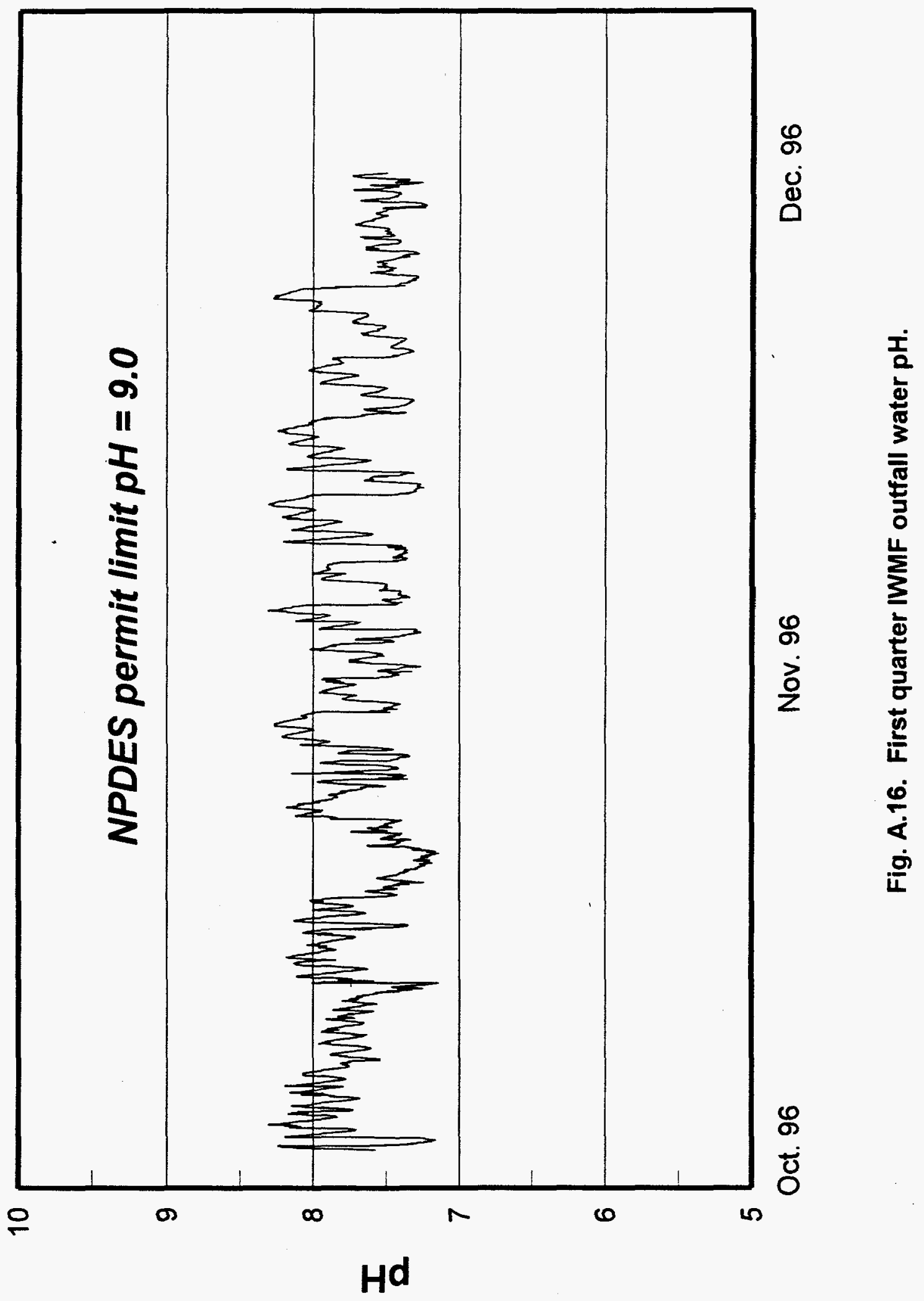




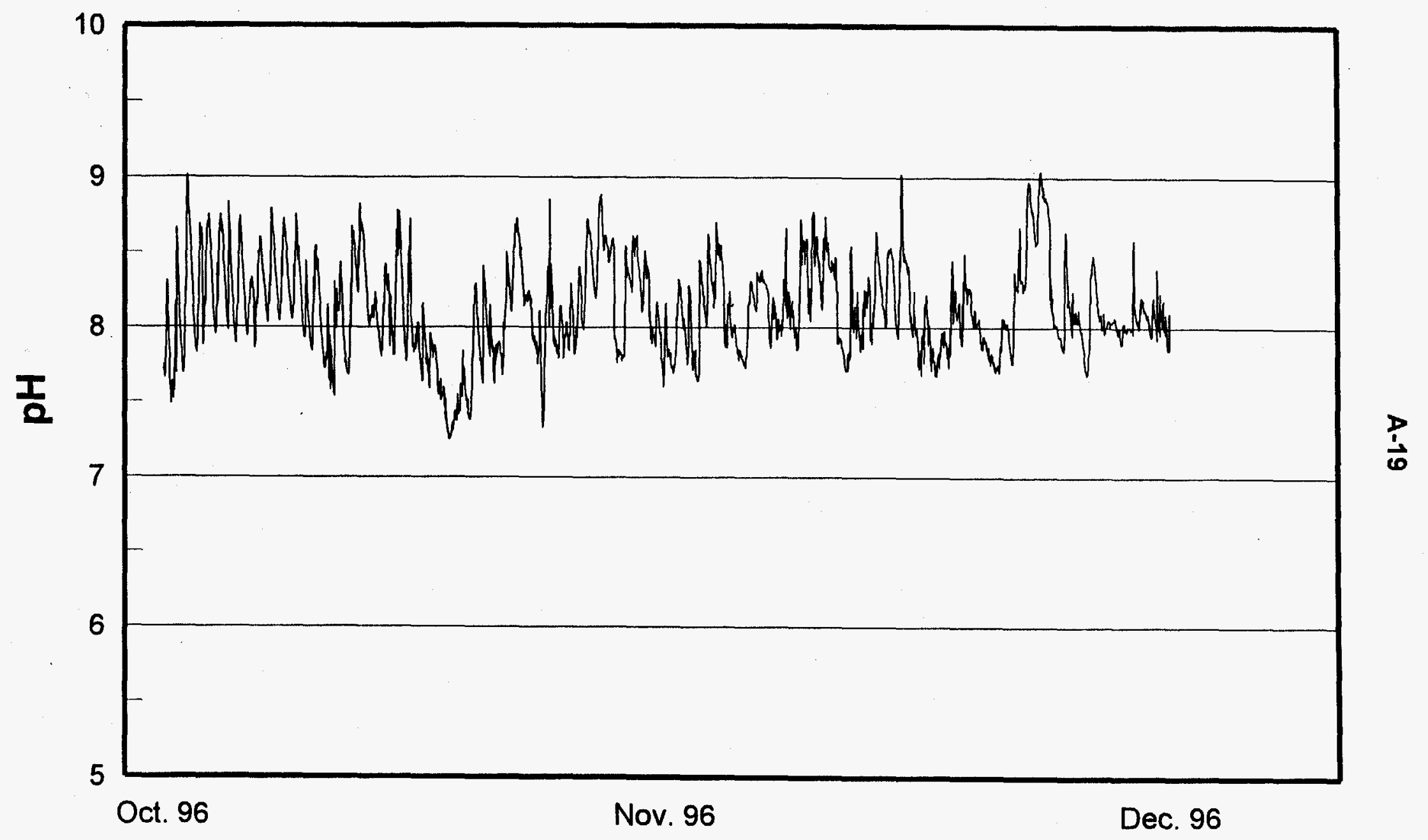

Fig. A.17. First quarter IWMF stormwater sump pH. 


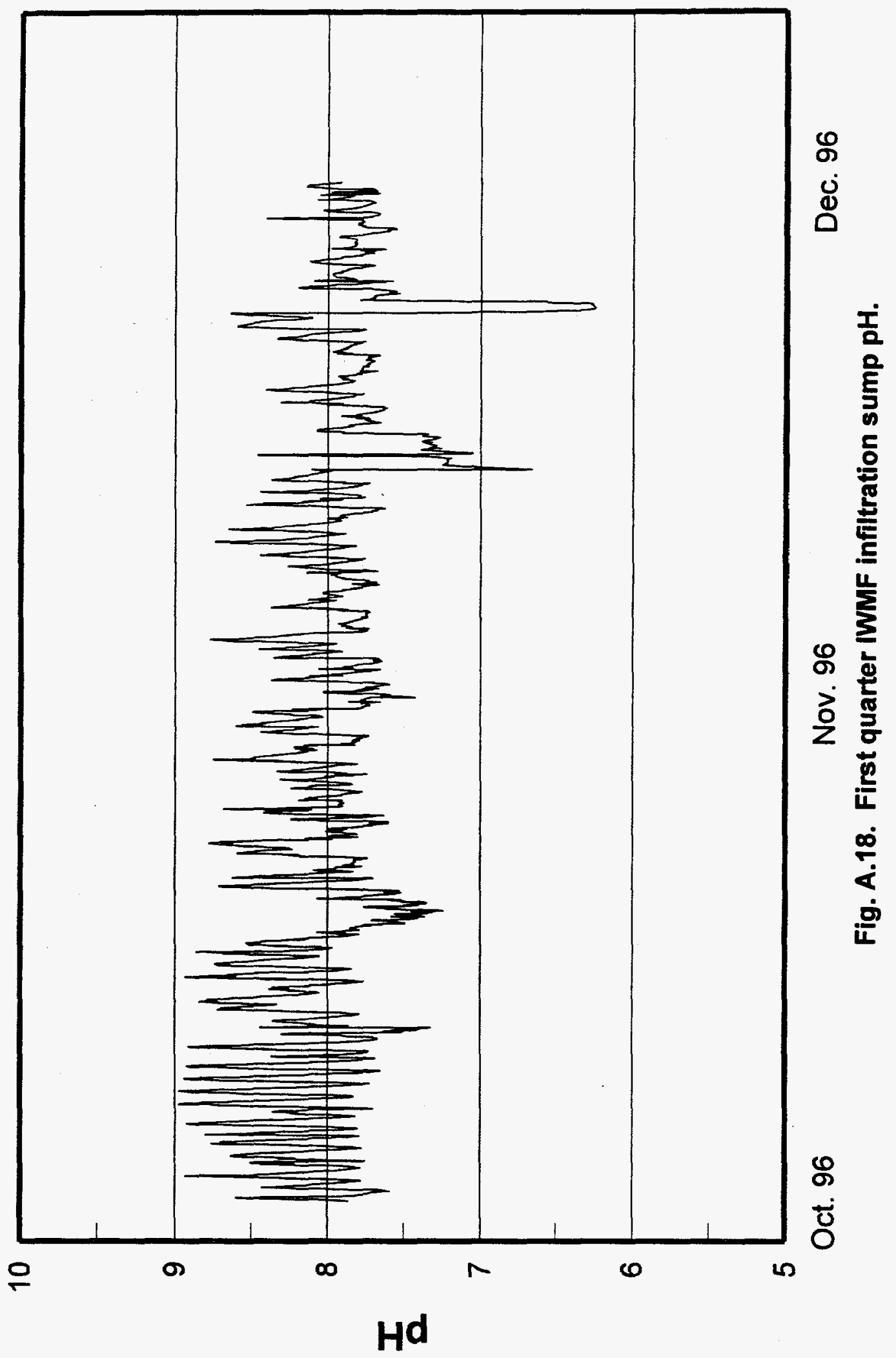




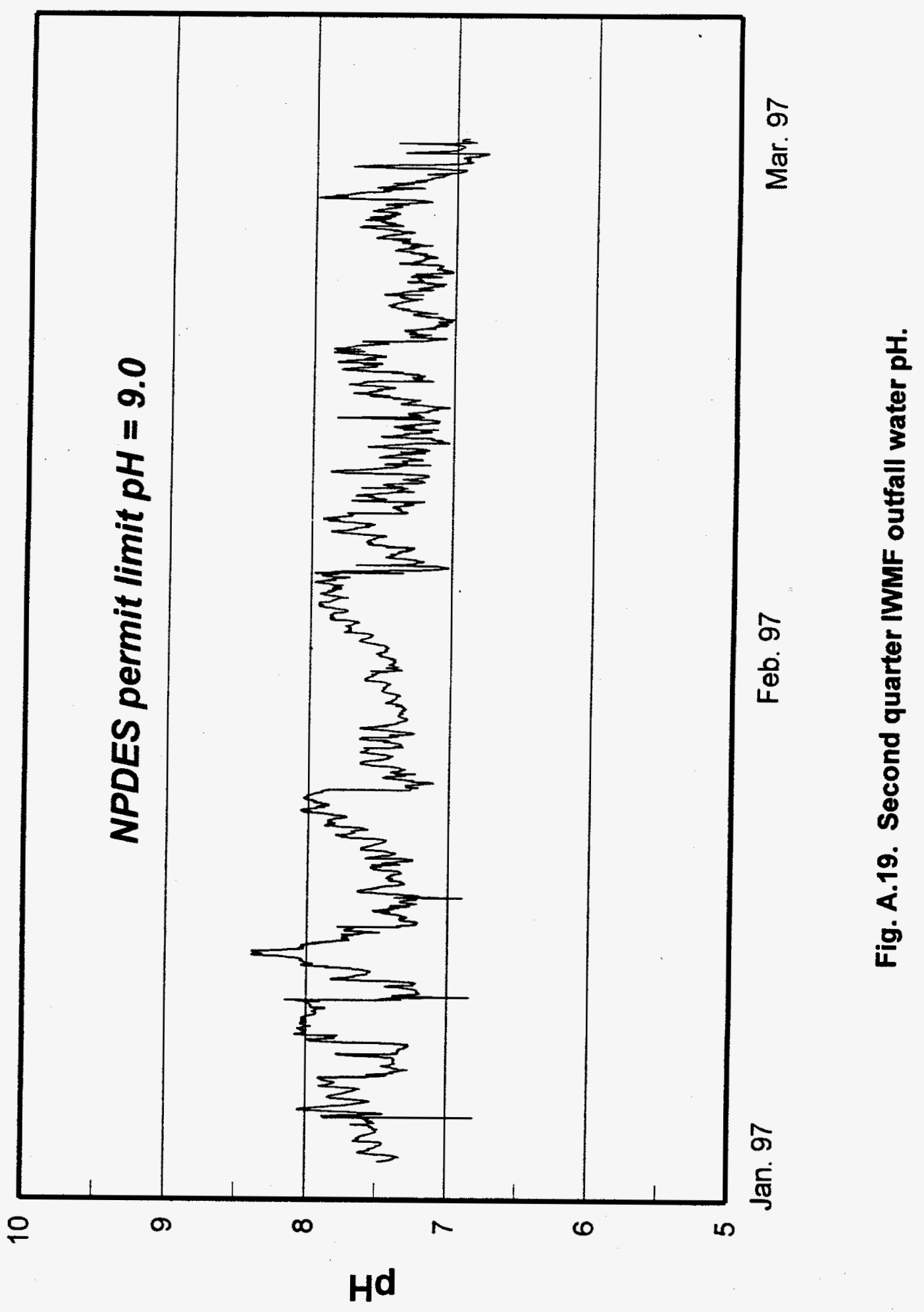




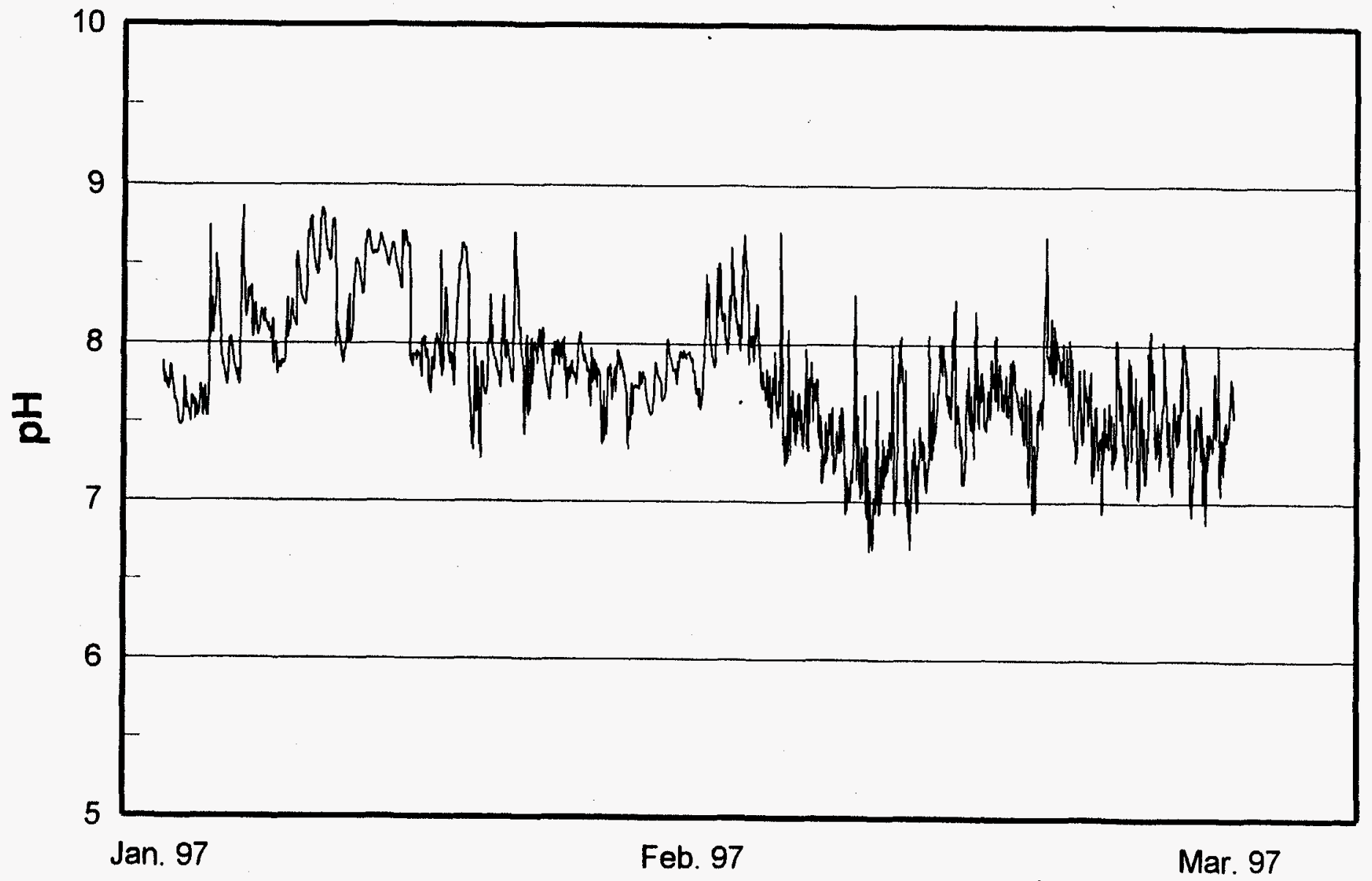

Fig. A.20. Second quarter IWMF stormwater sump pH. 
A-23

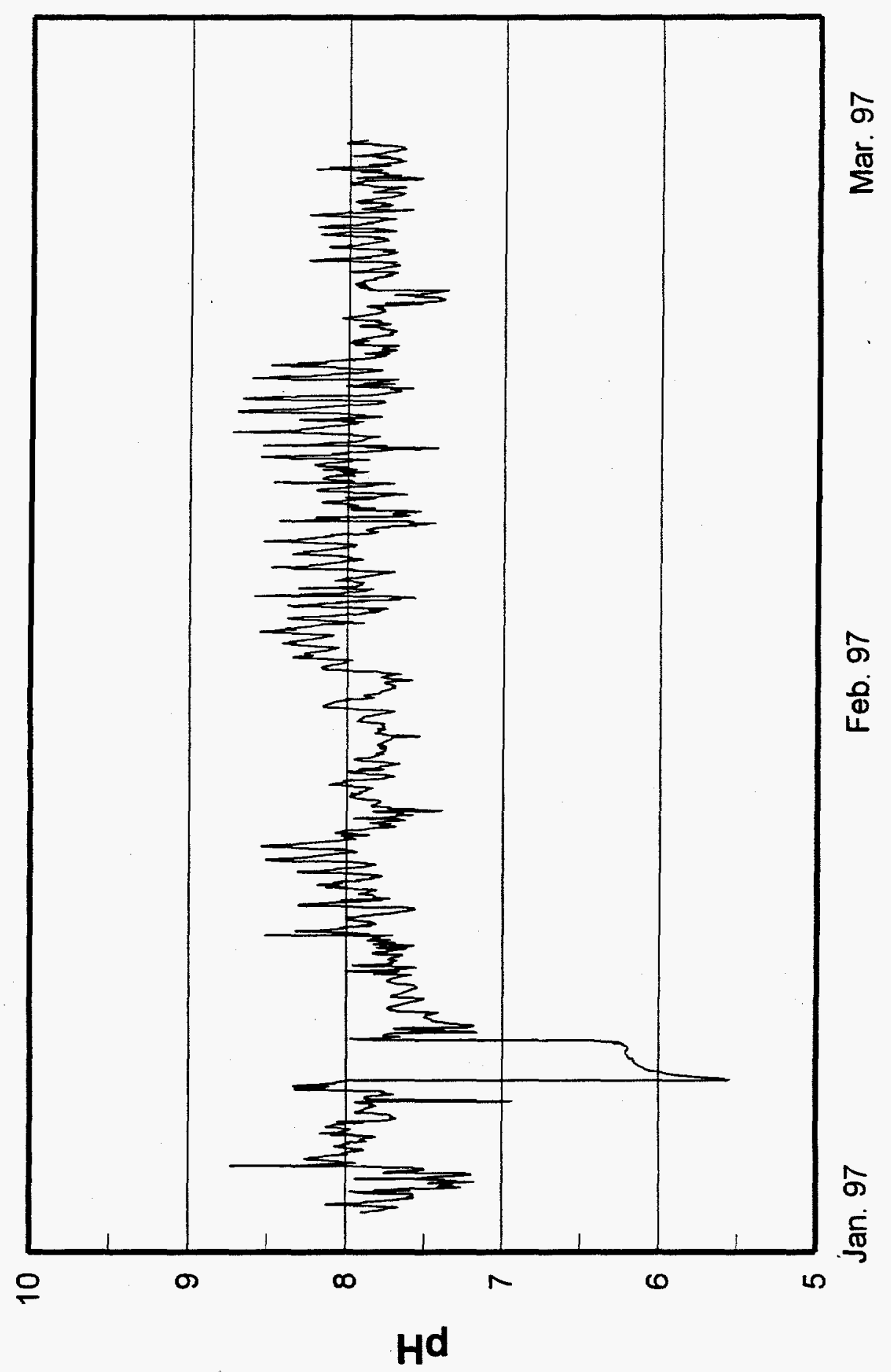

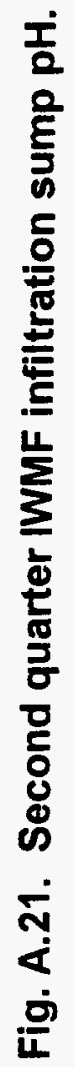




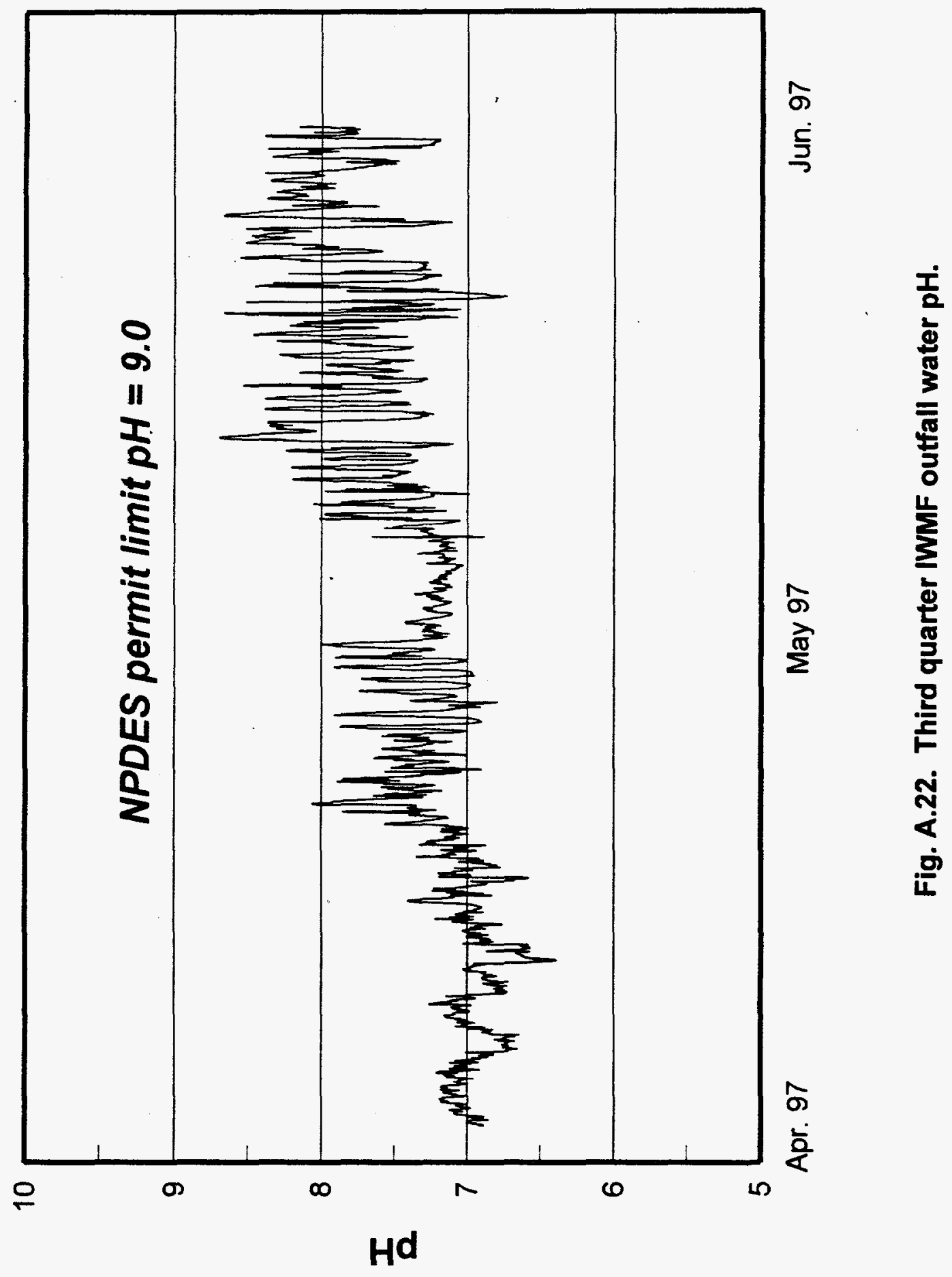




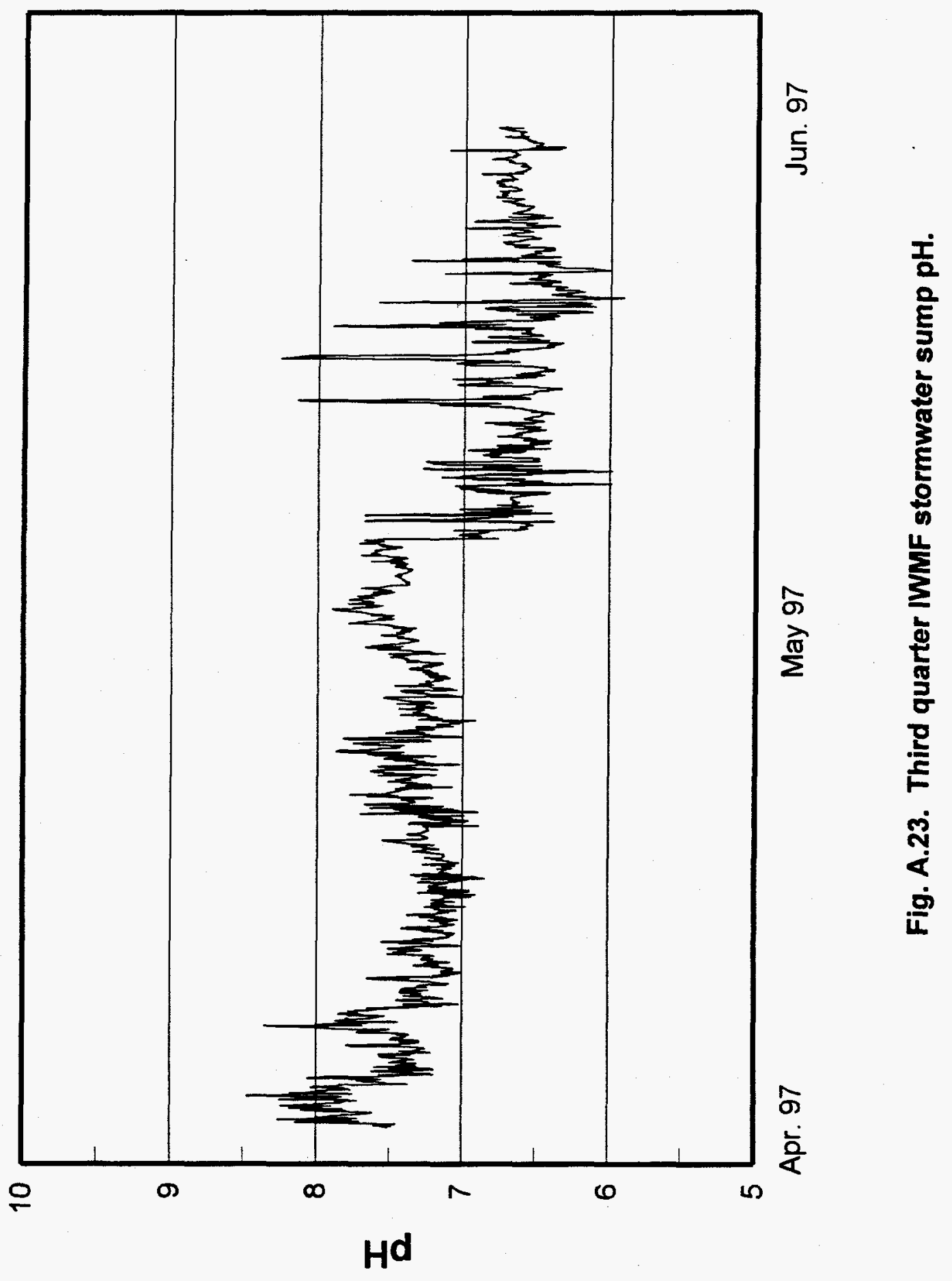




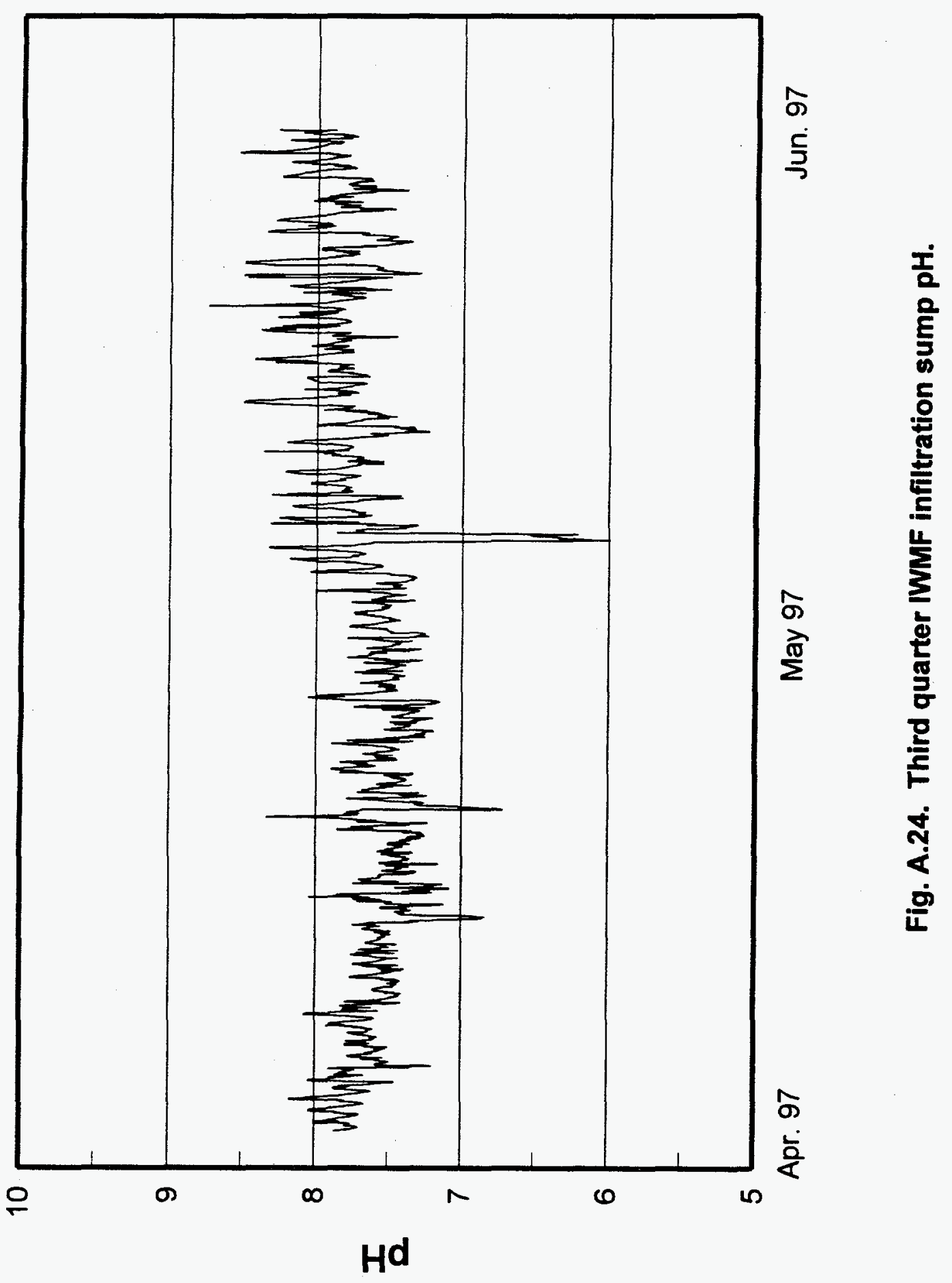




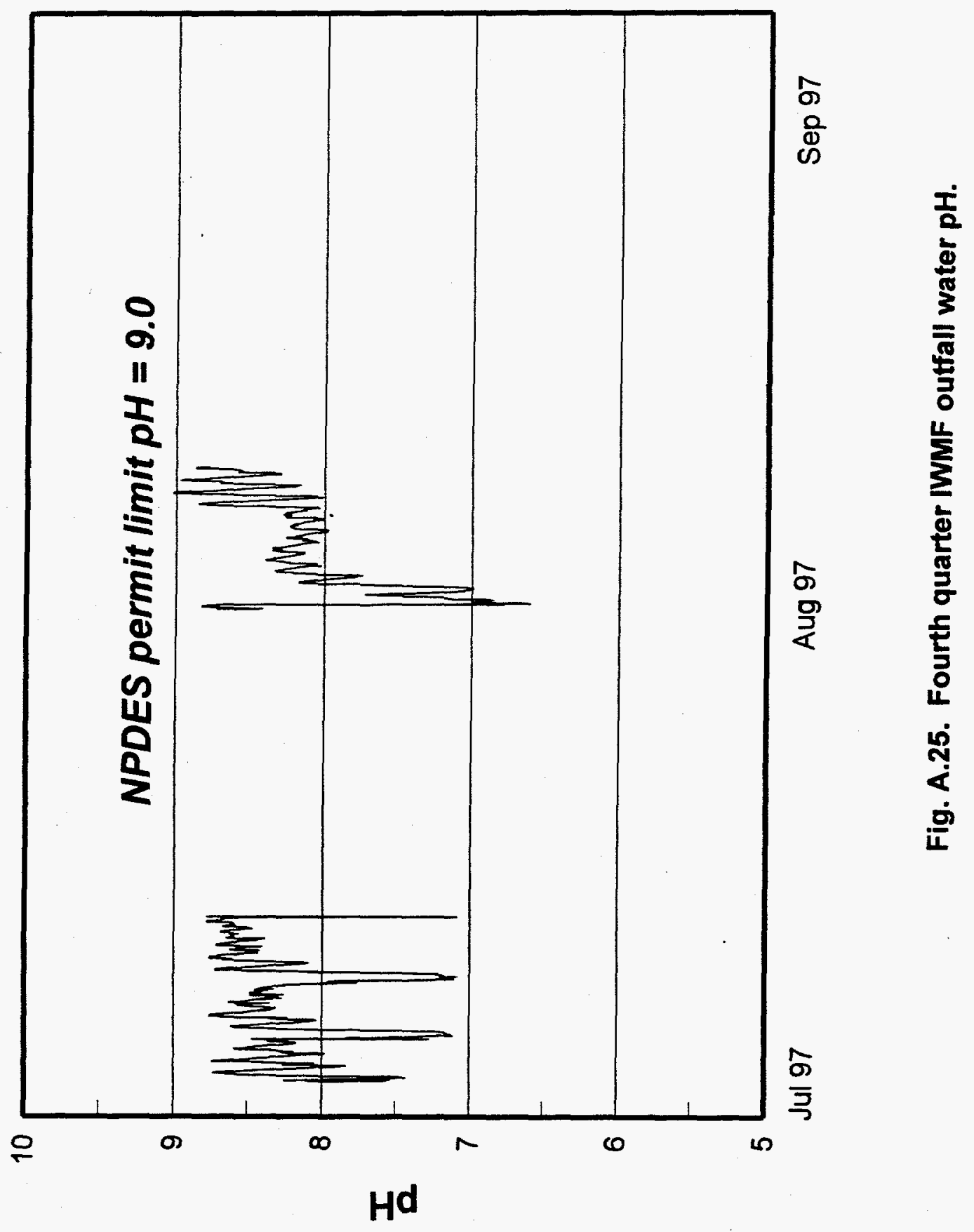




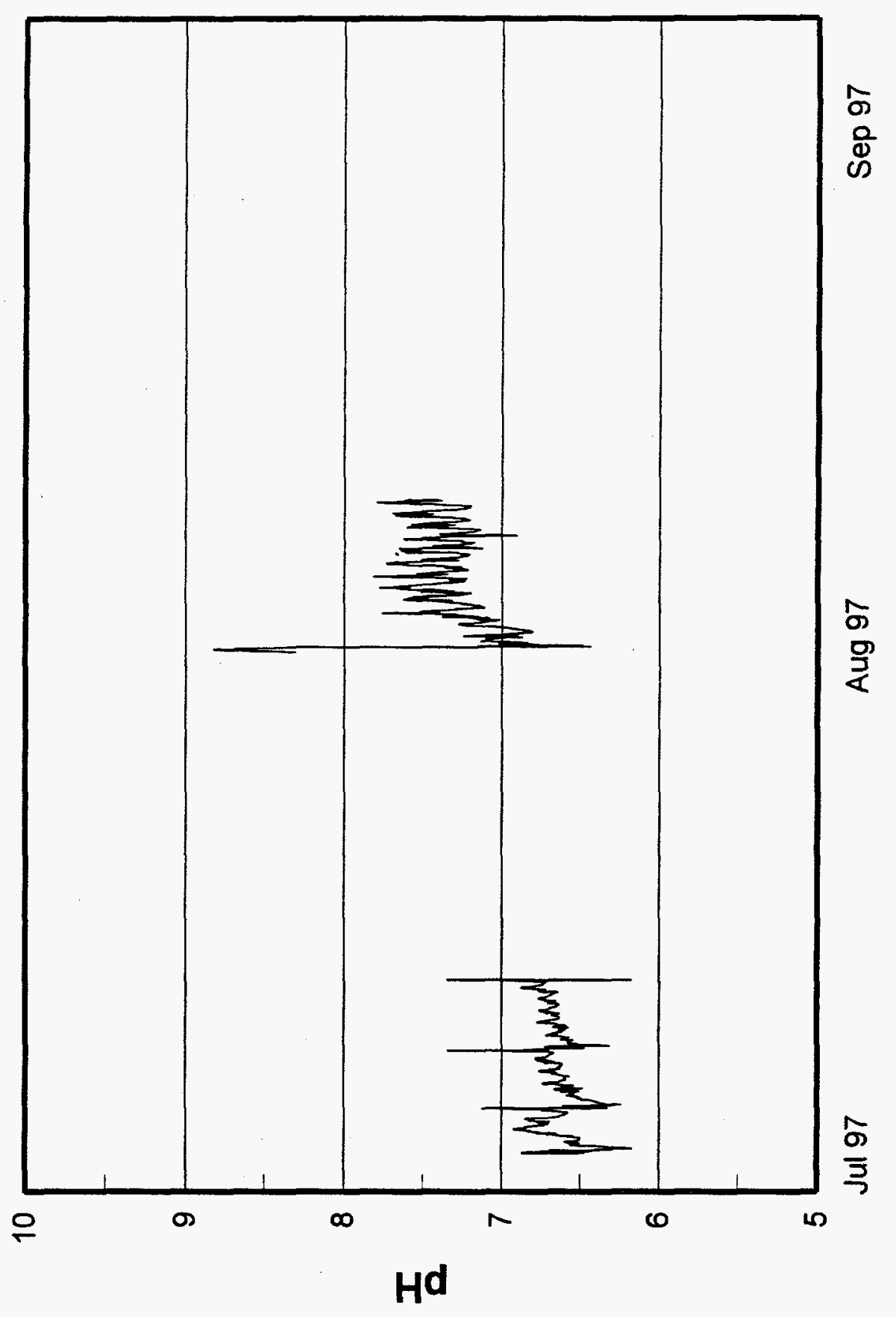

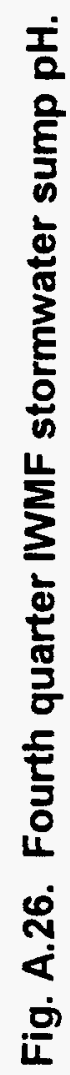




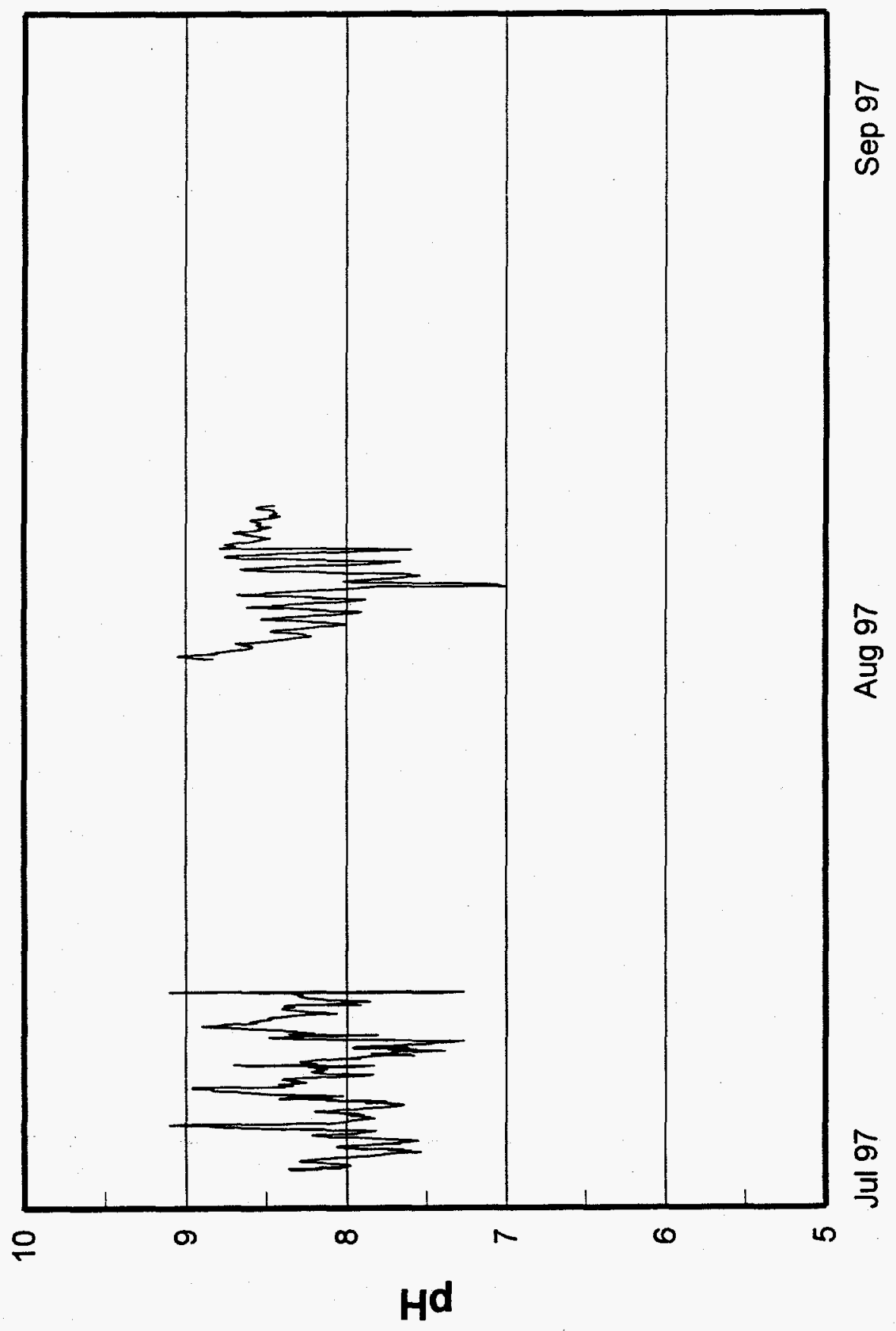

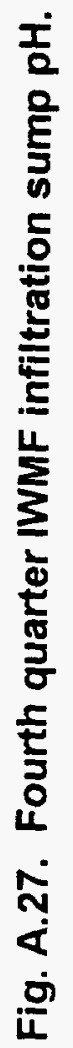




\section{A-30}

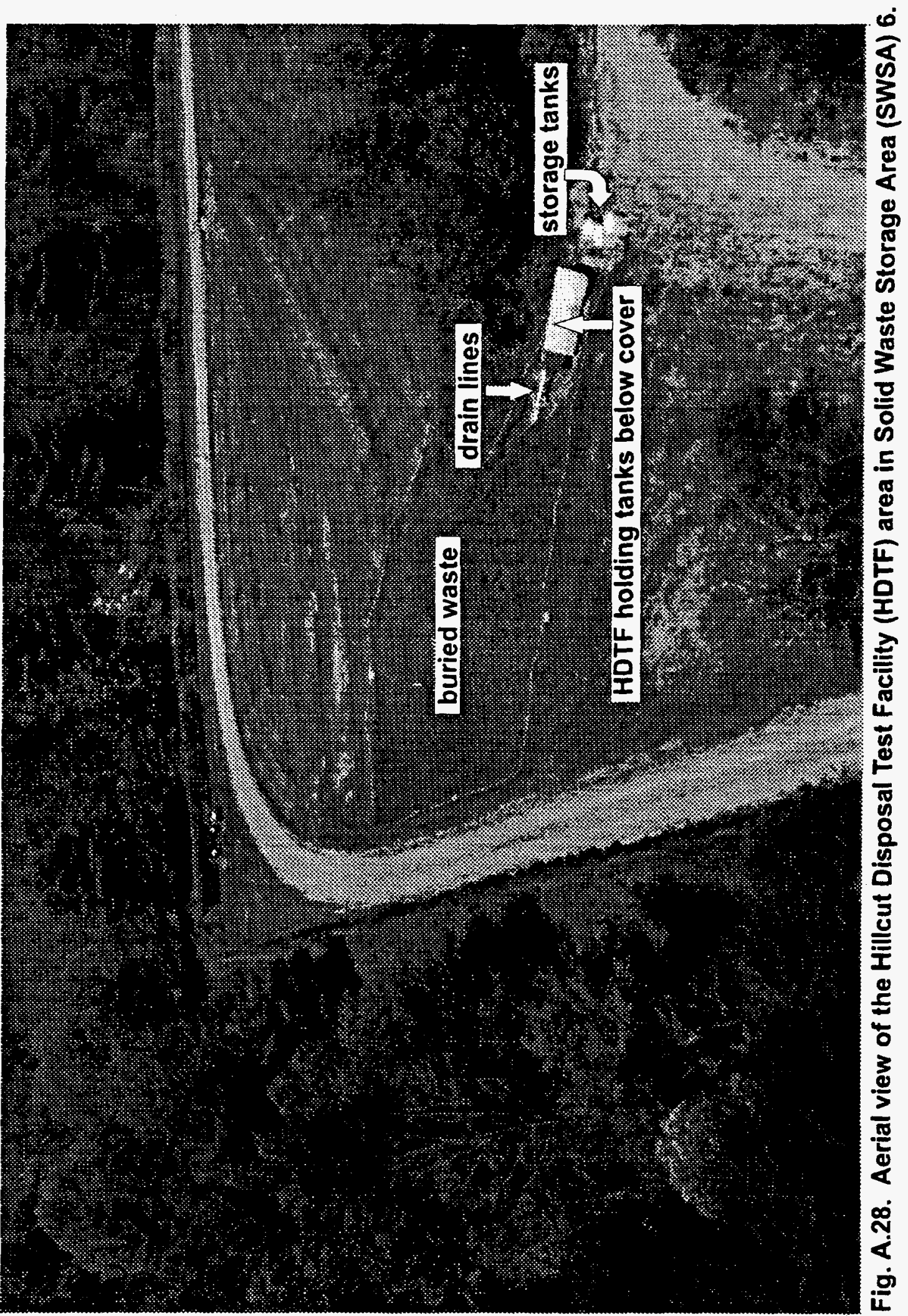




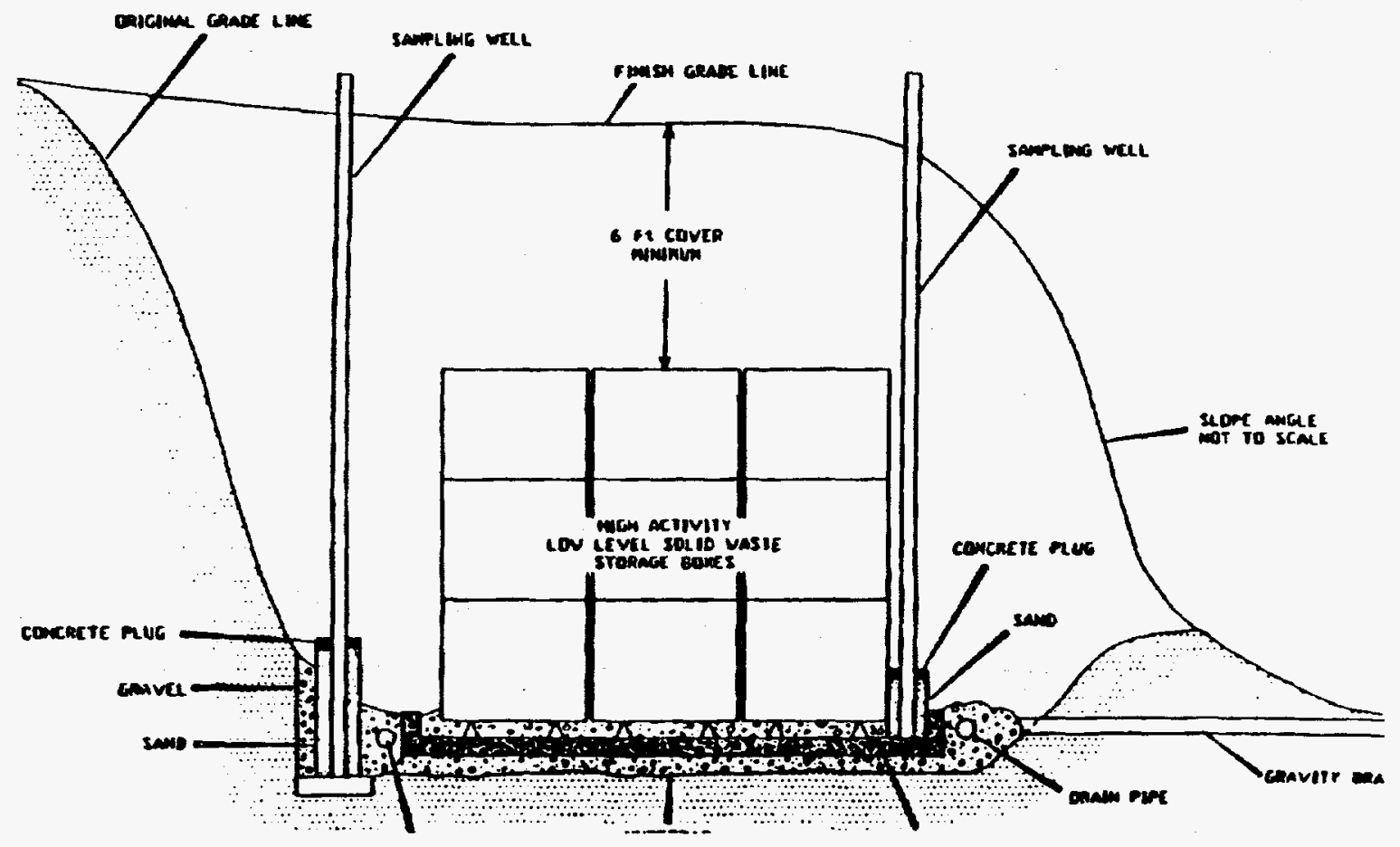

Fig. A.29. Cross sectional view through the Hillcut Disposal Test Facility (HDTF). 


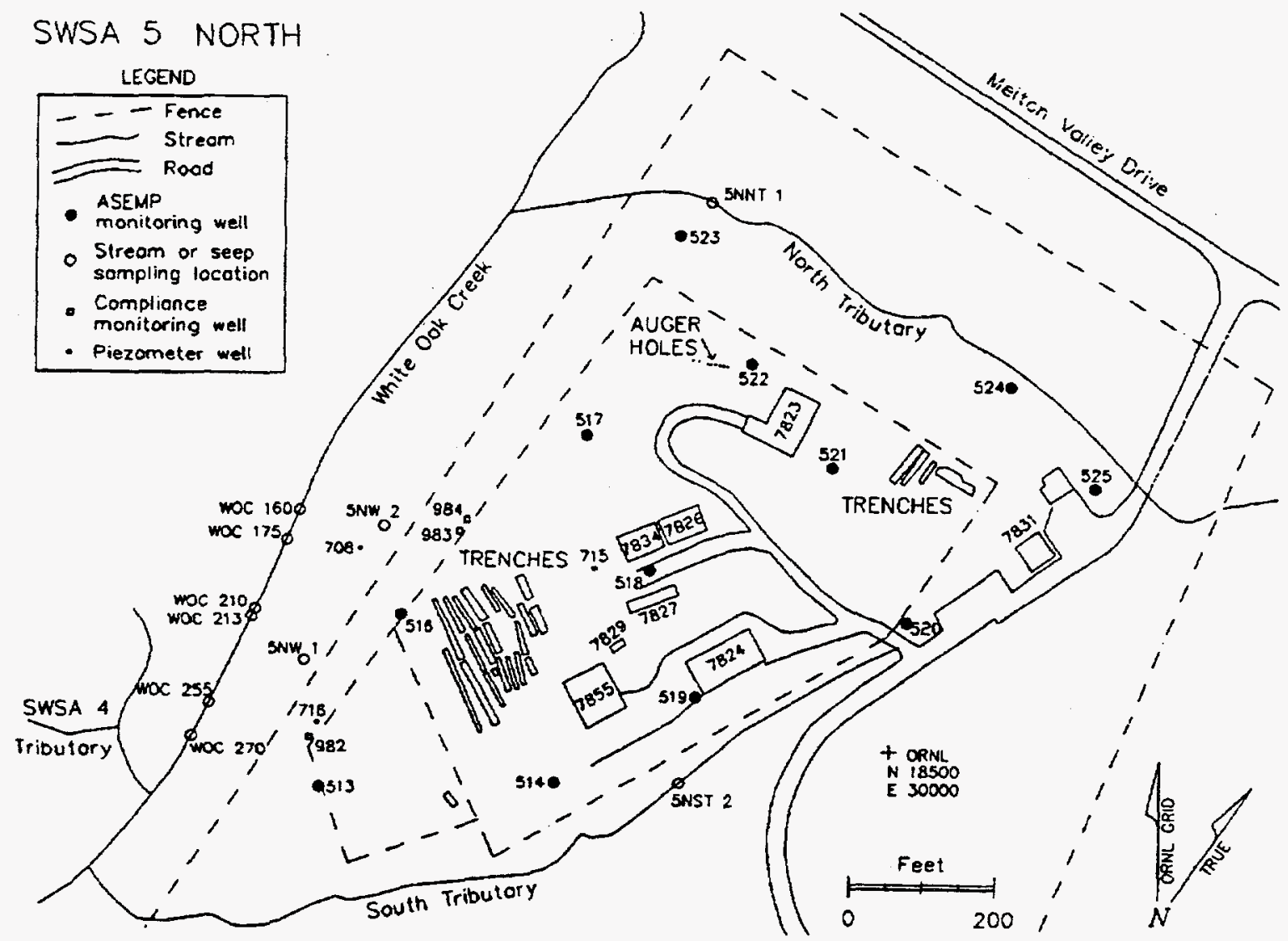

Fig. A.30. Transuranic waste storage areas, groundwater monitoring wells, and other major facilities in SWSA $5 \mathbf{N}$. 




Fig. A.31. Aerial view of Solid Waste Storage Area (SWSA) 5 North showing location of main TRU waste storage building sumps and other points of interest. 


\section{APPENDIX B DATA TABLES}


Table B.1. Runoff and French Drain samples from the Interim Waste Management Facility for FY97.

\begin{tabular}{|c|c|c|c|c|c|c|c|}
\hline Sample No. ${ }^{b}$ & Date & Gross $\alpha$ & Gross $\beta^{c}$ & ${ }^{40} \mathrm{~K}$ & ${ }^{60} \mathrm{Co}$ & ${ }^{137} \mathrm{Cs}$ & ${ }^{3} \mathrm{H}$ \\
\hline \multicolumn{8}{|c|}{ Stormwater sump: } \\
\hline IWMF/STM/333 & $10 / 22 / 96$ & $0.047 \pm 0.024$ & $-0.04 \pm 0.06$ & & & & \\
\hline IWMF/STM/334 & $10 / 22 / 96$ & $0.043 \pm 0.030$ & $0.46 \pm 0.09$ & $0.58 \pm 1.0$ & $<0.116$ & $<0.118$ & \\
\hline IWMF/STM/335 & $11 / 04 / 96$ & $-0.032 \pm 0.029$ & $-0.02 \pm 0.05$ & & & & \\
\hline IWMF/STM/336 & $11 / 04 / 96$ & $0.069 \pm 0.035$ & $0.58 \pm 0.09$ & $0.36 \pm 0.77$ & $<0.077$ & $<0.079$ & \\
\hline IWMF/STM/337 & $11 / 14 / 96$ & $0.150 \pm 0.045$ & $0.01 \pm 0.06$ & & & & \\
\hline IWMF/STM/338 & $11 / 14 / 96$ & $-0.034 \pm 0.02$ & $0.35 \pm 0.08$ & $<0.248$ & $<0.148$ & $<0.139$ & \\
\hline IWMF/STM/339 & $11 / 19 / 96$ & $0.018 \pm 0.020$ & $0.16 \pm 0.06$ & & & & \\
\hline IWMF/STM/340 & $11 / 19 / 96$ & $-0.052 \pm 0.006$ & $0.27 \pm 0.07$ & $<2.84$ & $<0.148$ & $<0.142$ & \\
\hline IWMF/STM/341 & $11 / 26 / 96$ & $0.039 \pm 0.028$ & $0.06 \pm 0.07$ & & & & \\
\hline IWMF/STM/342 & $11 / 26 / 96$ & $0.049 \pm 0.027$ & $0.44 \pm 0.08$ & $<2.82$ & $<0.143$ & $<0.128$ & \\
\hline IWMF/STM/343 & $12 / 02 / 96$ & $-0.007 \pm 0.002$ & $0.07 \pm 0.06$ & & & & \\
\hline IWMF/STM/344 & $12 / 02 / 96$ & $-0.034 \pm 0.026$ & $0.40 \pm 0.14$ & $<2.48$ & $<0.126$ & $<0.103$ & \\
\hline IWMF/STM/345 & $12 / 09 / 96$ & $0.001 \pm 0.011$ & $0.01 \pm 0.06$ & & & & \\
\hline IWMF/STM/346 & $12 / 09 / 96$ & $0.002 \pm 0.018$ & $0.21 \pm 0.07$ & $<2.62$ & $<0.139$ & $<0.130$ & \\
\hline IWMF/STM/347 & $12 / 30 / 96$ & $0.037 \pm 0.031$ & $0.02 \pm 0.06$ & & & & \\
\hline IWMF/STM/348 & $12 / 30 / 96$ & $-0.035 \pm 0.019$ & $0.19 \pm 0.08$ & $<2.47$ & $<0.150$ & $<0.121$ & \\
\hline IWMF/STM/349 & $01 / 02 / 97$ & $-0.034 \pm 0.019$ & $0.02 \pm 0.06$ & & & & \\
\hline IWMF/STM/350 & $01 / 02 / 97$ & $0.023 \pm 0.022$ & $0.30 \pm 0.08$ & $0.87 \pm 0.78$ & $<0.121$ & $<0.127$ & \\
\hline IWMF/STM/351 & $01 / 07 / 97$ & $0.039 \pm 0.036$ & $0.04 \pm 0.06$ & & & & \\
\hline IWMF/STM/352 & $01 / 07 / 97$ & $0.005 \pm 0.013$ & $0.38 \pm 0.08$ & $<2.48$ & $<0.163$ & $<0.133$ & \\
\hline IWMF/STM/353 & $01 / 10 / 97$ & $-0.015 \pm 0.022$ & $0.04 \pm 0.06$ & & & & \\
\hline IWMF/STM/354 & $01 / 10 / 97$ & $-0.016 \pm 0.008$ & $0.45 \pm 0.08$ & $1.45 \pm 1.01$ & $<0.148$ & $<0.145$ & \\
\hline IWMF/STM/355 & $01 / 16 / 97$ & $-0.004 \pm 0.015$ & $-0.02 \pm 0.06$ & & & & \\
\hline IWMF/STM/356 & $01 / 16 / 97$ & $0.051 \pm 0.035$ & $0.51 \pm 0.08$ & $<3.36$ & $<0.16$ & $<0.13$ & \\
\hline
\end{tabular}


Table B.1 (continued)

\begin{tabular}{|c|c|c|c|c|c|c|c|}
\hline Sample No.' & Date & Gross $\alpha$ & Gross $\beta^{c}$ & ${ }^{40} \mathrm{~K}$ & ${ }^{60} \mathrm{Co}$ & ${ }^{137} \mathrm{Cs}$ & ${ }^{3} \mathrm{H}$ \\
\hline IWMF/STM/357 & $01 / 24 / 97$ & $0.001 \pm 0.021$ & $0.10 \pm 0.07$ & $<3.16$ & $<0.16$ & $<0.139$ & \\
\hline IWMF/STM/358 & $01 / 28 / 97$ & $-0.038 \pm 0.006$ & $0.28 \pm 0.08$ & $<2.57$ & $<0.13$ & $<0.110$ & $54 \pm 15$ \\
\hline IWMF/STM/359 & $01 / 28 / 97$ & $0.005 \pm 0.037$ & $-0.08 \pm 0.06$ & & & & \\
\hline IWMF/STM/360 & $02 / 04 / 97$ & $0.012 \pm 0.025$ & $0.41 \pm 0.08$ & $0.35 \pm 1.04$ & $<0.15$ & $<0.14$ & \\
\hline IWMF/STM/361 & $02 / 04 / 97$ & $-0.022 \pm 0.004$ & $-0.03 \pm 0.06$ & & & & \\
\hline IMMF/STM/362 & $02 / 10 / 97$ & $-0.003 \pm 0.027$ & $0.39 \pm 0.08$ & $4.2 \pm 0.9$ & $<0.14$ & $<0.125$ & \\
\hline IWMF/STM/363 & $02 / 10 / 97$ & $0.041 \pm 0.023$ & $0.10 \pm 0.06$ & & & & \\
\hline IWMF/STM/364 & $02 / 24 / 97$ & $-0.015 \pm 0.023$ & $0.46 \pm 0.08$ & $0.16 \pm 0.48$ & $<0.121$ & $<0.127$ & \\
\hline IWMF/STM/365 & $02 / 24 / 97$ & $0.015 \pm 0.019$ & $0.04 \pm 0.06$ & & & & \\
\hline IWMF/STM/366 & $02 / 27 / 97$ & $0.035 \pm 0.026$ & $0.34 \pm 0.08$ & $-0.52 \pm 0.97$ & $<0.266$ & $<0.259$ & \\
\hline IWMF/STM/367 & $02 / 27 / 97$ & $0.017 \pm 0.023$ & $-0.02 \pm 0.06$ & & & & \\
\hline IWMF/STM/368 & $03 / 03 / 97$ & $0.001 \pm 0.029$ & $0.24 \pm 0.08$ & $<2.93$ & $<0.14$ & $0.068 \pm 0.054$ & \\
\hline IWMF/STM/369 & $03 / 03 / 97$ & $0.012 \pm 0.026$ & $0.018 \pm 0.005$ & & & & \\
\hline IWMF/STM/370 & $03 / 11 / 97$ & $-0.002 \pm 0.026$ & $0.47 \pm 0.08$ & $<2.02$ & $<0.14$ & $<0.161$ & \\
\hline IWMF/STM/371 & $03 / 11 / 97$ & $-0.007 \pm 0.037$ & $-0.12 \pm 0.06$ & & & & \\
\hline IWMF/STM/372 & $03 / 17 / 97$ & $0.035 \pm 0.034$ & $0.30 \pm 0.08$ & $<3.27$ & $<0.15$ & $<0.144$ & \\
\hline IWMF/STM/373 & $03 / 17 / 97$ & $-0.005 \pm 0.026$ & $-0.01 \pm 0.06$ & & & & \\
\hline IWMF/STM/374 & $03 / 20 / 97$ & $0.085 \pm 0.037$ & $0.36 \pm 0.08$ & $<2.04$ & $<0.14$ & $<0.16$ & \\
\hline IWMF/STM/375 & $03 / 20 / 97$ & $0.059 \pm 0.030$ & $0.18 \pm 0.07$ & & & & \\
\hline IWMF/STM/376 & $03 / 31 / 97$ & $0.033 \pm 0.033$ & $0.44 \pm 0.09$ & $-0.24 \pm 0.67$ & $<0.17$ & $-0.08 \pm 0.05$ & \\
\hline IWMF/STM/377 & $03 / 31 / 97$ & $0.129 \pm 0.131$ & $0.59 \pm 0.63$ & & & & \\
\hline IWMF/STM/378 & $04 / 07 / 97$ & $0.07 \pm 0.04$ & $0.48 \pm 0.74$ & $<2.77$ & $<0.13$ & $<0.12$ & $74 \pm 15$ \\
\hline IWMF/STM/379 & $04 / 07 / 97$ & $-0.000 \pm 0.012$ & $0.06 \pm 0.05$ & & & & \\
\hline IWMF/STM/380 & $04 / 15 / 97$ & $0.026 \pm 0.024$ & $0.30 \pm 0.07$ & $-0.58 \pm 0.38$ & $<0.15$ & $<0.13$ & \\
\hline IWMF/STM/381 & $04 / 15 / 97$ & $-0.004 \pm 0.026$ & $-0.04 \pm 0.05$ & & & & \\
\hline
\end{tabular}


Table B.1 (continued)

\begin{tabular}{|c|c|c|c|c|c|c|c|}
\hline Sample No. & Date & Gross $\alpha$ & Gross $\beta^{c}$ & ${ }^{40} \mathrm{~K}$ & ${ }^{60} \mathrm{Co}$ & ${ }^{137} \mathrm{Cs}$ & ${ }^{3} \mathrm{H}$ \\
\hline IWMF/STM/382 & $04 / 15 / 97$ & $0.030 \pm 0.026$ & $0.44 \pm 0.07$ & $<0.37$ & $<0.15$ & $<0.13$ & \\
\hline blank-D.I. H2O & $04 / 22 / 97$ & $0.012 \pm 0.012$ & $-0.01 \pm 0.06$ & & & & \\
\hline IWMF/STM/383 & $04 / 29 / 97$ & $0.010 \pm 0.017$ & $-0.14 \pm 0.05$ & & & & \\
\hline IWMF/STM/384 & $04 / 29 / 97$ & $0.048 \pm 0.020$ & $-0.12 \pm 0.06$ & $-1.09 \pm 0.8$ & $<0.24$ & $<0.24$ & \\
\hline IWMF/STM/385 & $05 / 07 / 97$ & $-0.036 \pm 0.005$ & $0.04 \pm 0.06$ & & & & \\
\hline IWMF/STM/386 & 05/07/97 & $0.036 \pm 0.026$ & $0.27 \pm 0.07$ & $0.27 \pm 0.44$ & $<0.14$ & $<0.13$ & \\
\hline IWMF/STM/387 & $05 / 13 / 97$ & $-0.012 \pm 0.018$ & $-0.03 \pm 0.06$ & & & & \\
\hline IWMF/STM/388 & 05/13/97 & $0.026 \pm 0.018$ & $0.48 \pm 0.08$ & $<3.87$ & $<0.14$ & $<0.13$ & \\
\hline IWMF/STM/389 & $05 / 27 / 97$ & $-0.002 \pm 0.013$ & $0.10 \pm 0.07$ & & & & \\
\hline IWMF/STM/390 & $05 / 27 / 97$ & $-0.025 \pm 0.014$ & $0.30 \pm 0.07$ & $1.09 \pm 0.67$ & $<0.15$ & $-0.02 \pm 0.06$ & \\
\hline IWMF/STM/391 & $05 / 29 / 97$ & $-0.037 \pm 0.014$ & $0.08 \pm 0.06$ & & & & \\
\hline IWMF/STM/392 & $05 / 29 / 97$ & $-0.010 \pm 0.026$ & $0.14 \pm 0.06$ & $<3.33$ & $<0.24$ & $<0.24$ & $33 \pm 11$ \\
\hline IWMF/STM/393 & $06 / 02 / 97$ & $0.059 \pm 0.030$ & $-0.08 \pm 0.07$ & & & & \\
\hline IWMF/STM/394 & $06 / 02 / 97$ & $-0.003 \pm 0.013$ & $0.26 \pm 0.07$ & $0.81 \pm 0.82$ & $<0.21$ & $<0.23$ & \\
\hline IWMF/STM/395 & $06 / 09 / 97$ & $-0.014 \pm 0.003$ & $0.05 \pm 0.06$ & & & & \\
\hline IWMF/STM/396 & $06 / 09 / 97$ & $-0.041 \pm 0.026$ & $0.30 \pm 0.08$ & $-1.37 \pm 0.83$ & $<0.24$ & $<0.23$ & \\
\hline IWMF/STM/397 & $06 / 13 / 97$ & $0.044 \pm 0.043$ & $0.07 \pm 0.13$ & & & & \\
\hline IWMF/STM/398 & 06/13/97 & $0.055 \pm 0.050$ & $0.44 \pm 0.17$ & $-2.24 \pm 0.81$ & $<0.24$ & $<0.25$ & \\
\hline IWMF/STM/399 & $06 / 16 / 97$ & $-0.05 \pm 0.07$ & $-0.12 \pm 0.18$ & & & & \\
\hline IWMF/STM/400 & $06 / 16 / 97$ & $0.152 \pm 0.107$ & $0.78 \pm 0.26$ & $-1.14 \pm 0.87$ & $<0.26$ & $<0.26$ & \\
\hline IWMF/STM/401 & $06 / 25 / 97$ & $0.030 \pm 0.044$ & $0.35 \pm 0.12$ & & & & \\
\hline IWMF/STM/402 & $06 / 25 / 97$ & $-0.005 \pm 0.050$ & $0.55 \pm 0.13$ & $0.20 \pm 0.40$ & $<0.16$ & $<0.13$ & \\
\hline IWMF/STM/403 & $07 / 01 / 97$ & $-0.022 \pm 0.022$ & $0.16 \pm 0.07$ & & & & \\
\hline IWMF/STM/404 & $07 / 01 / 97$ & $0.052 \pm 0.035$ & $0.44 \pm 0.09$ & $1.12 \pm 0.46$ & $<0.13$ & $<0.12$ & \\
\hline
\end{tabular}


Table B.1 (continued)

\begin{tabular}{|c|c|c|c|c|c|c|c|}
\hline Sample No. ${ }^{b}$ & Date & Gross $\alpha$ & Gross $\beta^{c}$ & ${ }^{40} \mathrm{~K}$ & ${ }^{80} \mathrm{Co}$ & ${ }^{137} \mathrm{Cs}$ & ${ }^{3} \mathrm{H}$ \\
\hline IWMF/STM/405 & $07 / 11 / 97$ & $-0.170 \pm 0.040$ & $-0.04 \pm 0.12$ & & & & \\
\hline IWMF/STM/406 & $07 / 11 / 97$ & $0.000 \pm 0.040$ & $0.22 \pm 0.13$ & $<4.25$ & $0.14 \pm 0.08$ & $<0.14$ & \\
\hline IWMF/STM/406B & $09 / 24 / 97$ & & & $<4.38$ & $<0.17$ & $<0.13$ & \\
\hline IWMF/STM/407 & $08 / 19 / 97$ & $0.004 \pm 0.028$ & $0.10 \pm 0.02$ & & & & \\
\hline IWMF/STM/408 & $08 / 19 / 97$ & $0.067 \pm 0.039$ & $0.55 \pm 0.07$ & $<4.48$ & $<0.16$ & $<0.12$ & \\
\hline IWMF STM & $09 / 11 / 97$ & $0.067 \pm 0.033$ & $0.55 \pm 0.10$ & $<3.12$ & $<0.14$ & $<0.13$ & \\
\hline IWMF/STM/409 & $09 / 25 / 97$ & $0.048 \pm 0.028$ & $0.01 \pm 0.06$ & & & & \\
\hline IWMF/STM/410 & $09 / 25 / 97$ & $0.052 \pm 0.037$ & $0.28 \pm 0.07$ & $<3.62$ & $<0.13$ & $<0.13$ & \\
\hline \multicolumn{8}{|l|}{ Infiltration sump: } \\
\hline IWMF/INF/180 & 10/22/96 & $0.010 \pm 0.029$ & $1.00 \pm 0.10$ & $2.09 \pm 1.07$ & $<0.137$ & $<0.127$ & \\
\hline IWMF/INF/182 & $11 / 04 / 96$ & $0.026 \pm 0.024$ & $0.95 \pm 0.10$ & $2.63 \pm 0.67$ & $<0.089$ & $<0.084$ & \\
\hline IWMF/INF/184 & $11 / 14 / 96$ & $0.031 \pm 0.038$ & $0.34 \pm 0.08$ & & & & \\
\hline IWMF/INF/186 & $11 / 19 / 96$ & $0.031 \pm 0.039$ & $0.34 \pm 0.08$ & $<2.38$ & $<0.101$ & $<0.101$ & \\
\hline IWMF/INF/188 & $11 / 26 / 96$ & $0.003 \pm 0.020$ & $0.54 \pm 0.09$ & $1.37 \pm 1.01$ & $<0.144$ & $<0.134$ & \\
\hline IWMF/INF/190 & $12 / 02 / 96$ & $0.060 \pm 0.050$ & $0.28 \pm 0.12$ & $<2.89$ & $<0.133$ & $<0.128$ & \\
\hline IWMF/INF/192 & $12 / 09 / 96$ & $-0.023 \pm 0.023$ & $0.63 \pm 0.08$ & $2.20 \pm 0.99$ & $<0.133$ & $<0.133$ & \\
\hline IWMF/INF/194 & $12 / 30 / 96$ & $0.004 \pm 0.017$ & $0.64 \pm 0.09$ & $<3.09$ & $<0.149$ & $<0.135$ & \\
\hline IWMF/INF/196 & $01 / 02 / 97$ & $0.086 \pm 0.038$ & $0.68 \pm 0.09$ & $<2.59$ & $<0.130$ & $<0.126$ & \\
\hline IWMF/INF/198 & $01 / 07 / 97$ & $0.040 \pm 0.028$ & $1.30 \pm 0.10$ & $<2.66$ & $<0.145$ & $<0.123$ & \\
\hline IWMF/INF/200 & $01 / 10 / 97$ & $0.042 \pm 0.014$ & $0.65 \pm 0.10$ & $1.01 \pm 0.98$ & $<0.148$ & $<0.140$ & \\
\hline IWMF/INF/202 & $01 / 16 / 97$ & $0.031 \pm 0.023$ & $0.70 \pm 0.10$ & $0.94 \pm 1.09$ & $<0.149$ & $<0.135$ & \\
\hline IWMF/INF/204 & $01 / 23 / 97$ & $0.001 \pm 0.024$ & $0.63 \pm 0.09$ & $0.08 \pm 0.96$ & $<0.145$ & $<0.124$ & \\
\hline IWMF/INF/206 & $01 / 24 / 97$ & $0.010 \pm 0.019$ & $0.21 \pm 0.07$ & $<2.82$ & $<0.142$ & $<0.137$ & $59 \pm 15$ \\
\hline IWMF/INF/208 & $01 / 28 / 97$ & $0.030 \pm 0.190$ & $0.43 \pm 0.08$ & $5.91 \pm 0.97$ & $<0.149$ & $<0.135$ & \\
\hline IWMF/INF/210 & $02 / 04 / 97$ & $-0.015 \pm 0.004$ & $0.73 \pm 0.09$ & $0.22 \pm 0.87$ & $<0.151$ & $<0.121$ & \\
\hline
\end{tabular}


Table B.1 (continued)

\begin{tabular}{|c|c|c|c|c|c|c|c|}
\hline Sample No. & Date & Gross $\alpha$ & Gross $\beta^{c}$ & ${ }^{40} \mathrm{~K}$ & ${ }^{60} \mathrm{Co}$ & ${ }^{137} \mathrm{Cs}$ & ${ }^{3} \mathrm{H}$ \\
\hline IWMF/INF/212 & 02/10/97 & $0.048 \pm 0.029$ & $0.63 \pm 0.09$ & $0.41 \pm 0.48$ & $<0.135$ & $<0.127$ & \\
\hline IWMF/INF/214 & 02/24/97 & $0.063 \pm 0.040$ & $0.34 \pm 0.07$ & $-1.94 \pm 0.96$ & $<0.282$ & $<0.274$ & \\
\hline IWMF/INF/216 & $02 / 27 / 97$ & $-0.028 \pm 0.020$ & $0.76 \pm 0.01$ & $-2.71 \pm 0.72$ & $<0.216$ & $<0.242$ & \\
\hline IWMF/INF/218 & $03 / 03 / 97$ & $0.023 \pm 0.023$ & $0.53 \pm 0.10$ & $-1.75 \pm 0.82$ & $<0.240$ & $<0.222$ & \\
\hline IWMF/INF/220 & $03 / 11 / 97$ & $-0.090 \pm 0.060$ & $0.64 \pm 0.09$ & $-0.15 \pm 0.58$ & $<0.151$ & $<0.175$ & \\
\hline IWMF/INF/222 & $03 / 17 / 97$ & $0.027 \pm 0.030$ & $0.89 \pm 0.11$ & $<2.74$ & $<0.12$ & $<0.12$ & \\
\hline IMMF/NF/224 & $03 / 20 / 97$ & $-0.018 \pm 0.026$ & $0.59 \pm 0.09$ & $1.95 \pm 1.14$ & $<0.16$ & $<0.14$ & \\
\hline IWMF/INF/226 & $03 / 31 / 97$ & $0.015 \pm 0.020$ & $0.70 \pm 0.09$ & $0.96 \pm 1.11$ & $<0.15$ & $<0.13$ & $124 \pm 16$ \\
\hline IWMF/INF/228 & 04/07/97 & $0.011 \pm 0.031$ & $0.85 \pm 0.09$ & $1.46 \pm 0.62$ & $<0.16$ & $-0.03 \pm 0.05$ & \\
\hline IWMF/INF/230 & $04 / 15 / 97$ & $0.022 \pm 0.022$ & $0.59 \pm 0.09$ & $<3.82$ & $<0.12$ & $<0.11$ & \\
\hline IWMF/INF/232 & $04 / 22 / 97$ & $0.011 \pm 0.020$ & $0.85 \pm 0.11$ & $3.82 \pm 1.03$ & $<0.10$ & $<0.10$ & \\
\hline IWMF/INF/234 & $04 / 29 / 97$ & $-0.003 \pm 0.028$ & $0.55 \pm 0.09$ & $<4.00$ & $<0.14$ & $<0.12$ & \\
\hline blank-D.I. H2O & 04/29/97 & & & $<3.07$ & $<0.12$ & $<0.10$ & \\
\hline IWMF/INF/236 & 05/07/97 & $0.048 \pm 0.040$ & $0.44 \pm 0.08$ & $<3.82$ & $<0.14$ & $<0.12$ & \\
\hline IWMF/INF/238 & $05 / 13 / 97$ & $0.063 \pm 0.033$ & $0.63 \pm 0.09$ & $1.40 \pm 1.36$ & $<0.15$ & $<0.13$ & \\
\hline IWMF/INF/240 & $05 / 27 / 97$ & $-0.013 \pm 0.020$ & $0.74 \pm 0.10$ & $7.59 \pm 1.46$ & $<0.15$ & $<0.15$ & \\
\hline IWMF/INF/242 & $05 / 29 / 97$ & & $0.63 \pm 0.09$ & $0.69 \pm 0.08$ & $<0.16$ & $-0.02 \pm 0.04$ & $37 \pm 11$ \\
\hline IWMF/INF/244 & $06 / 02 / 97$ & $0.011 \pm 0.018$ & $0.67 \pm 0.09$ & $-0.30 \pm 0.68$ & $<0.16$ & $-0.04 \pm 0.05$ & \\
\hline IWMF/INF/246 & $06 / 09 / 97$ & $-0.067 \pm 0.008$ & $1.33 \pm 0.12$ & $-1.07 \pm 0.86$ & $<0.25$ & $<0.25$ & \\
\hline IWMF/INF/248 & $06 / 13 / 97$ & $0.293 \pm 0.133$ & $3.14 \pm 0.37$ & $0.43 \pm 0.46$ & $<0.14$ & $<0.13$ & \\
\hline IWMF/INF/250 & $06 / 16 / 97$ & $-0.010 \pm 0.104$ & $1.96 \pm 0.35$ & $1.66 \pm 0.44$ & $<0.13$ & $<0.13$ & \\
\hline IWMF/INF/252 & $06 / 25 / 97$ & $0.021 \pm 0.037$ & $1.04 \pm 0.18$ & $<3.91$ & $<0.14$ & $<0.12$ & \\
\hline IWMF/INF/254 & $07 / 01 / 97$ & $0.041 \pm 0.039$ & $1.76 \pm 0.13$ & $<3.14$ & $<0.12$ & $<0.11$ & \\
\hline IWMF/INF/256 & 07/11/97 & $0.030 \pm 0.055$ & $2.03 \pm 0.22$ & $<4.5$ & $<0.16$ & $0.10 \pm 0.06$ & \\
\hline IWMF/INF/258 & 08/19/97 & $0.044 \pm 0.037$ & $2.66 \pm 0.17$ & $1.95 \pm 1.36$ & $<0.12$ & $<0.12$ & \\
\hline
\end{tabular}


Table B.1 (continued)

\begin{tabular}{|c|c|c|c|c|c|c|c|}
\hline Sample No.' & Date & Gross $\alpha$ & Gross $\beta^{c}$ & ${ }^{10} \mathrm{~K}$ & ${ }^{\circ 0} \mathrm{Co}$ & ${ }^{137} \mathrm{Cs}$ & ${ }^{3} \mathrm{H}$ \\
\hline IWMF-BLK & 09/10/97 & $0.700 \pm 0.024$ & $-2.30 \pm 0.05$ & & & & \\
\hline IWMF-PAD 1 & $09 / 10 / 97$ & $-0.076 \pm 0.015$ & $1.52 \pm 0.12$ & $<3.77$ & $<0.14$ & $<0.11$ & \\
\hline IMMF INFILTRAT & $09 / 11 / 97$ & $0.085 \pm 0.039$ & $1.33 \pm 0.12$ & $<4.5$ & $<0.16$ & $<0.14$ & \\
\hline IWMF/INF/260 & $09 / 25 / 97$ & $0.037 \pm 0.026$ & $0.52 \pm 0.09$ & $<3.85$ & $<0.14$ & $<0.12$ & \\
\hline \multicolumn{8}{|l|}{ French drain: } \\
\hline FD111996 & $11 / 19 / 96$ & $0.097 \pm 0.047$ & $0.14 \pm 0.07$ & $<2.40$ & $<0.124$ & $<0.134$ & $69 \pm 17$ \\
\hline FD020797 & $02 / 07 / 97$ & $0.071 \pm 0.033$ & $0.19 \pm 0.06$ & $4.2 \pm 1.8$ & $<0.26$ & $<0.29$ & $52 \pm 30$ \\
\hline FD032697 & $03 / 26 / 97$ & $0.030 \pm 0.035$ & $0.11 \pm 0.12$ & $-0.45 \pm 1.03$ & $<0.29$ & $-0.08 \pm 0.08$ & $48 \pm 15$ \\
\hline FD043097 & $04 / 30 / 97$ & $0.096 \pm 0.041$ & $0.09 \pm 0.06$ & $0.59 \pm 2.04$ & $<0.32$ & $<0.27$ & $56 \pm 15$ \\
\hline FD091097 & $09 / 10 / 97$ & $-0.740 \pm 0.015$ & $0.83 \pm 0.06$ & $0.36 \pm 1.07$ & $<0.13$ & $<0.12$ & \\
\hline
\end{tabular}

- All data are in Becquerel per liter, mean \pm 1 standard error (counting error only); blank spaces indicate analysis not performed; less than (<) data reported from ESD lab.

- $\mathrm{MMM}=$ Interim Waste Management Facility; STM = stormwater; INF = infiltration; FD = French drain.

${ }^{\circ}$ Gross beta analysis does not include tritium. 
Table B.2. Soil radionuclide data from the IWMF area."

\begin{tabular}{ccccccc}
\hline Sample No. & Date & Gross $\alpha$ & Gross $\beta$ & ${ }^{60}$ Co & ${ }^{137}$ Cs & ${ }^{40} \mathrm{~K}$ \\
\hline IWMF1 & $09 / 15 / 97$ & $450 \pm 165$ & $660 \pm 140$ & $<0.220$ & $<0.265$ & $990 \pm 40$ \\
IWMF2 & $09 / 15 / 97$ & $175 \pm 85$ & $340 \pm 115$ & $<0.242$ & $<0.250$ & $930 \pm 40$ \\
IWMF3 & $09 / 15 / 97$ & $290 \pm 110$ & $760 \pm 135$ & $2.9 \pm 1.1$ & $4.6 \pm 1.2$ & $710 \pm 35$ \\
IWMF4 & $09 / 15 / 97$ & $430 \pm 165$ & $290 \pm 110$ & $<0.250$ & $<0.235$ & $650 \pm 30$ \\
IWMF5 & $09 / 15 / 97$ & $390 \pm 155$ & $1200 \pm 160$ & $<0.225$ & $<0.265$ & $750 \pm 40$ \\
IWMF6 & $09 / 15 / 97$ & $210 \pm 85$ & $540 \pm 130$ & $<0.235$ & $<0.232$ & $880 \pm 40$ \\
IWMF7 & $09 / 15 / 97$ & $510 \pm 170$ & $710 \pm 130$ & $<0.228$ & $<0.254$ & $1000 \pm 110$ \\
IWMF8 & $09 / 15 / 97$ & $190 \pm 90$ & $1300 \pm 190$ & $<0.244$ & $<0.285$ & $770 \pm 40$ \\
IWMF9 & $09 / 15 / 97$ & $420 \pm 155$ & $890 \pm 155$ & $<0.222$ & $2.8 \pm 1.9$ & $760 \pm 40$ \\
IWMF10 & $09 / 15 / 97$ & $550 \pm 175$ & $630 \pm 140$ & $<0.225$ & $<0.275$ & $1300 \pm 110$ \\
\hline
\end{tabular}

${ }^{a}$ All data are in $\mathrm{Bq} / \mathrm{kg}$, mean \pm standard error (counting error only). 
Table B.3. Runoff samples from the Hillcut Disposal Test Facility."

\begin{tabular}{cccccc}
\hline Date & Gross $\alpha$ & Gross $\beta^{\circ}$ & ${ }^{40} \mathrm{~K}$ & ${ }^{80} \mathrm{Co}$ & ${ }^{137} \mathrm{Cs}$ \\
\hline Pad runoff: & & & & \\
$11 / 26 / 96$ & $0.024 \pm 0.023$ & $0.68 \pm 0.09$ & $<2.53$ & $<0.14$ & $<0.16$ \\
$12 / 02 / 96$ & $0.018 \pm 0.041$ & $0.75 \pm 0.15$ & $<2.17$ & $<0.13$ & $<0.11$ \\
$12 / 23 / 96$ & $0.033 \pm 0.031$ & $0.77 \pm 0.10$ & $<4.95$ & $<0.35$ & $<0.21$ \\
$01 / 04 / 97$ & $0.064 \pm 0.030$ & $0.39 \pm 0.10$ & $<3.50$ & $<0.25$ & $<0.21$ \\
$01 / 16 / 97$ & $0.005 \pm 0.039$ & $0.69 \pm 0.16$ & $0.47 \pm 1.81$ & $<0.29$ & $<0.24$ \\
$03 / 03 / 97$ & $0.014 \pm 0.022$ & $0.52 \pm 0.09$ & $4.36 \pm 0.69$ & $<0.084$ & $<0.082$ \\
$03 / 04 / 97$ & $0.027 \pm 0.019$ & $0.54 \pm 0.08$ & $<5.85$ & $<0.50$ & $<0.48$ \\
$03 / 26 / 97$ & $0.004 \pm 0.020$ & $0.21 \pm 0.06$ & $<3.77$ & $<0.32$ & $<0.31$ \\
$05 / 27 / 97$ & $0.003 \pm 0.020$ & $0.55 \pm 0.09$ & $<5.57$ & $<0.19$ & $<0.24$ \\
$06 / 16 / 97$ & $0.366 \pm 0.150$ & $1.78 \pm 0.30$ & $<2.77$ & $<0.28$ & $<0.22$ \\
\multicolumn{7}{l}{} & & & & \\
Underpad runoff: & & & & \\
$12 / 23 / 96$ & $0.035 \pm 0.023$ & $0.49 \pm 0.15$ & $1.61 \pm 1.20$ & $<0.24$ & $<0.23$ \\
$01 / 16 / 97$ & $-0.005 \pm 0.030$ & $0.41 \pm 0.16$ & $<5.59$ & $<0.31$ & $<0.26$ \\
$03 / 03 / 97$ & $0.044 \pm 0.032$ & $0.27 \pm 0.09$ & $<3.92$ & $<0.36$ & $<0.39$ \\
$03 / 04 / 97$ & $0.017 \pm 0.025$ & $0.24 \pm 0.08$ & & & \\
$06 / 16 / 97$ & $0.207 \pm 0.100$ & $0.07 \pm 0.29$ & $<6.40$ & $<0.46$ & $<0.52$ \\
\hline
\end{tabular}

all data are in $\mathrm{Bq} / \mathrm{L}$, mean \pm 1 standard error (counting error only); blank spaces indicate not analysis not performed.

${ }^{b}$ Gross beta analysis does not include tritium. 
B-11

TABLE B.4. SAMPLES FROM SWSA 5 NORTH SUMPS

\begin{tabular}{|c|c|c|c|c|c|c|c|}
\hline Date & \multicolumn{2}{|c|}{ Gross $\alpha$} & \multicolumn{2}{|c|}{ Gross $\beta^{b}$} & ${ }^{40} \mathrm{~K}$ & ${ }^{60} \mathrm{Co}$ & ${ }^{137} \mathrm{Cs}$ \\
\hline \multicolumn{8}{|c|}{$7826-1$} \\
\hline $10 / 03 / 96$ & & & & & $1.24 \pm 0.89$ & $<0.11$ & $<0.11$ \\
\hline $12 / 10 / 96$ & 0.022 & \pm 0.026 & 0.15 & \pm 0.07 & $<5.56$ & $<0.24$ & $<0.23$ \\
\hline $01 / 15 / 97$ & 0.023 & \pm 0.033 & 0.02 & \pm 0.06 & $0.11 \pm 1.67$ & $<0.30$ & $<0.31$ \\
\hline $02 / 19 / 97$ & 0.070 & \pm 0.042 & -0.05 & \pm 0.06 & $4.22 \pm 1.42$ & $<0.30$ & $<0.26$ \\
\hline $03 / 18 / 97$ & -0.014 & \pm 0.019 & 0.21 & \pm 0.07 & $<6.18$ & $<0.51$ & $<0.53$ \\
\hline $04 / 24 / 97$ & 0.030 & \pm 0.030 & 0.23 & \pm 0.14 & $<3.05$ & $<0.15$ & $<0.13$ \\
\hline $05 / 20 / 97$ & 0.090 & \pm 0.040 & 0.09 & \pm 0.06 & $<8.11$ & $<0.24$ & $<0.26$ \\
\hline $06 / 23 / 97$ & 0.040 & \pm 0.030 & 0.06 & \pm 0.06 & $0.67 \pm 1.81$ & $<0.32$ & $<0.25$ \\
\hline $07 / 25 / 97$ & 0.090 & \pm 0.040 & 0.36 & \pm 0.08 & $<5.46$ & $<0.29$ & $<0.21$ \\
\hline $08 / 21 / 97$ & -0.020 & \pm 0.030 & 0.34 & \pm 0.08 & $<8.52$ & $<0.25$ & $<0.25$ \\
\hline $09 / 22 / 97$ & 0.004 & \pm 0.030 & 0.11 & \pm 0.07 & $<7.56$ & $<0.25$ & $<0.25$ \\
\hline \multicolumn{8}{|c|}{$7826-2$} \\
\hline $12 / 10 / 96$ & 0.100 & \pm 0.050 & 0.12 & \pm 0.09 & $<4.56$ & $<0.26$ & $<0.24$ \\
\hline $04 / 24 / 97$ & 0.050 & \pm 0.030 & 0.08 & \pm 0.06 & $<5.85$ & $<0.27$ & $<0.22$ \\
\hline $06 / 23 / 97$ & -0.020 & \pm 0.020 & 0.06 & \pm 0.07 & $<7.0$ & $<0.61$ & $<0.58$ \\
\hline $07 / 25 / 97$ & 0.030 & \pm 0.030 & 0.24 & \pm 0.06 & $<7.40$ & $<0.25$ & $<0.22$ \\
\hline $08 / 21 / 97$ & 0.030 & \pm 0.040 & 0.34 & \pm 0.07 & $<4.35$ & $<0.16$ & $<0.13$ \\
\hline \multicolumn{8}{|c|}{$7834-1$} \\
\hline $12 / 10 / 96$ & -0.005 & \pm 0.027 & 0.18 & \pm 0.13 & $<4.96$ & $<0.24$ & $<0.24$ \\
\hline $01 / 15 / 97$ & 0.110 & \pm 0.050 & 0.18 & \pm 0.07 & $<5.44$ & $<0.24$ & $<0.23$ \\
\hline 02/19/97 & -0.017 & \pm 0.026 & 0.26 & \pm 0.08 & $5.30 \pm 1.67$ & $<0.25$ & $<0.25$ \\
\hline $03 / 18 / 97$ & 0.085 & \pm 0.046 & 0.33 & \pm 0.08 & $<2.75$ & $<0.28$ & $<0.27$ \\
\hline $04 / 24 / 97$ & 0.030 & \pm 0.020 & 0.24 & \pm 0.06 & $<7.81$ & $<0.28$ & $<0.28$ \\
\hline $05 / 20 / 97$ & 0.080 & \pm 0.040 & 0.44 & \pm 0.08 & $1.49 \pm 2.18$ & $<0.29$ & $<0.20$ \\
\hline $06 / 23 / 97$ & 0.120 & \pm 0.040 & 0.44 & \pm 0.09 & $-0.99 \pm 1.28$ & $<0.38$ & $<0.29$ \\
\hline $07 / 25 / 97$ & -0.040 & \pm 0.020 & 0.44 & \pm 0.09 & $<7.19$ & $<0.28$ & $<0.26$ \\
\hline $08 / 21 / 97$ & 0.060 & \pm 0.040 & 0.37 & \pm 0.07 & $<0.40$ & $<1.91$ & $<1.66$ \\
\hline $09 / 22 / 97$ & 0.060 & \pm 0.040 & 0.59 & \pm 0.09 & $<4.56$ & $<0.16$ & $<0.15$ \\
\hline
\end{tabular}




\section{B-12}

TABLE B.4 (continued)

\begin{tabular}{|c|c|c|c|c|c|c|c|}
\hline Date & Gro: & ss $\alpha$ & Gro & ss $\beta^{b}$ & ${ }^{40} \mathrm{~K}$ & ${ }^{80} \mathrm{Co}$ & ${ }^{137} \mathrm{Cs}$ \\
\hline \multicolumn{8}{|c|}{$7834-2$} \\
\hline $12 / 10 / 96$ & 0.090 & \pm 0.055 & 0.16 & \pm 0.13 & \multirow[t]{2}{*}{$<2.56$} & $<0.14$ & \multirow[t]{2}{*}{$<0.14$} \\
\hline $01 / 15 / 97$ & 0.014 & \pm 0.030 & 0.09 & 0.06 & & & \\
\hline $02 / 19 / 97$ & 0.044 & \pm 0.032 & 0.11 & 0.07 & $5.33 \pm 1.62$ & $<0.23$ & $<0.27$ \\
\hline $03 / 18 / 97$ & 0.032 & \pm 0.030 & 0.13 & \pm 0.07 & $<2.72$ & $<0.27$ & $<0.26$ \\
\hline $04 / 24 / 97$ & 0.078 & \pm 0.040 & 0.05 & \pm 0.06 & $<6.95$ & $<0.33$ & $<0.25$ \\
\hline $05 / 20 / 97$ & 0.040 & \pm 0.030 & 0.18 & \pm 0.07 & $<7.88$ & $<0.33$ & $0.19 \pm 0.14$ \\
\hline $06 / 23 / 97$ & 0.000 & \pm 0.040 & 0.15 & \pm 0.07 & $<6.73$ & $<0.47$ & $<0.55$ \\
\hline $07 / 25 / 97$ & 0.040 & \pm 0.040 & 0.26 & \pm 0.07 & $<7.85$ & $<0.25$ & $<0.22$ \\
\hline $08 / 21 / 97$ & 0.080 & \pm 0.040 & 0.48 & \pm 0.07 & $<8.18$ & $<0.31$ & $<0.29$ \\
\hline $09 / 22 / 97$ & 0.090 & \pm 0.040 & 0.59 & \pm 0.09 & $<4.61$ & $<0.16$ & $<0.14$ \\
\hline \multicolumn{8}{|c|}{$7834-3$} \\
\hline $12 / 10 / 96$ & 0.020 & \pm 0.050 & 1.30 & \pm 0.20 & $3.73 \pm 1.09$ & $<0.16$ & $<0.14$ \\
\hline $01 / 15 / 97$ & -0.012 & \pm 0.030 & 1.40 & 0.10 & $2.02 \pm 1.89$ & $<0.28$ & $<0.24$ \\
\hline $02 / 19 / 97$ & 0.030 & \pm 0.032 & 1.40 & 0.10 & $6.00 \pm 1.49$ & $<0.34$ & $<0.24$ \\
\hline $03 / 18 / 97$ & 0.026 & \pm 0.024 & 1.22 & \pm 0.11 & $<3.55$ & $<0.28$ & $<0.27$ \\
\hline $04 / 24 / 97$ & -0.060 & \pm 0.020 & 1.15 & \pm 0.11 & $<7.59$ & $<0.24$ & $<0.23$ \\
\hline $05 / 20 / 97$ & 0.020 & \pm 0.030 & 1.29 & \pm 0.12 & $1.70 \pm 2.12$ & $<0.22$ & $<0.26$ \\
\hline $06 / 23 / 97$ & 0.010 & \pm 0.020 & 1.44 & \pm 0.07 & $0.03 \pm 1.19$ & $<0.20$ & $<0.17$ \\
\hline $07 / 25 / 97$ & 0.020 & \pm 0.030 & 1.44 & 0.12 & $<8.08$ & $<0.33$ & $<0.21$ \\
\hline $08 / 21 / 97$ & 0.140 & \pm 0.050 & 1.55 & \pm 0.13 & $<8.66$ & $<0.30$ & $<2.20$ \\
\hline $09 / 22 / 97$ & 0.040 & \pm 0.030 & 2.03 & \pm 0.15 & $0.13 \pm 2.17$ & $<0.25$ & $<0.20$ \\
\hline \multicolumn{8}{|c|}{$7834-4$} \\
\hline $12 / 10 / 96$ & 0.260 & \pm 0.090 & 0.57 & \pm 0.15 & $<6.18$ & $<0.29$ & $<0.28$ \\
\hline $01 / 15 / 97$ & 0.600 & \pm 0.105 & 3.00 & \pm 0.15 & $2.18 \pm 1.86$ & $<0.29$ & $<0.27$ \\
\hline $02 / 19 / 97$ & 0.559 & \pm 0.100 & 2.60 & \pm 0.15 & $4.14 \pm 0.96$ & $<0.30$ & $<0.27$ \\
\hline $03 / 18 / 97$ & 0.329 & \pm 0.072 & 2.15 & \pm 0.14 & $2.19 \pm 1.90$ & $<0.30$ & $<0.25$ \\
\hline $04 / 24 / 97$ & 0.140 & \pm 0.050 & 2.37 & \pm 0.15 & $<8.27$ & $<0.22$ & $<0.23$ \\
\hline $05 / 20 / 97$ & 0.280 & \pm 0.150 & 1.76 & \pm 0.13 & $1.54 \pm 1.32$ & $<0.32$ & $<0.04$ \\
\hline $06 / 23 / 97$ & 0.240 & \pm 0.070 & 3.44 & \pm 0.17 & $3.37 \pm 1.04$ & $<0.31$ & $<0.31$ \\
\hline $07 / 25 / 97$ & 0.670 & \pm 0.130 & 3.70 & \pm 0.18 & $2.90 \pm 2.59$ & $<0.28$ & $<0.26$ \\
\hline $08 / 21 / 97$ & 0.440 & \pm 0.090 & 3.70 & \pm 0.18 & $<8.81$ & $<0.30$ & $<0.23$ \\
\hline $09 / 22 / 97$ & 0.520 & \pm 0.110 & 4.07 & \pm 0.20 & $<7.79$ & $<0.28$ & $<0.21$ \\
\hline
\end{tabular}




\section{B-13}

TABLE B.4 (continued)

\begin{tabular}{|c|c|c|c|c|c|c|c|c|}
\hline Date & \multicolumn{2}{|c|}{ Gross $\alpha$} & \multicolumn{2}{|c|}{ Gross $\beta^{b}$} & \multicolumn{2}{|c|}{${ }^{40} \mathrm{~K}$} & \multirow[t]{2}{*}{${ }^{60} \mathrm{Co}$} & \multirow[t]{2}{*}{${ }^{137} \mathrm{Cs}$} \\
\hline \multicolumn{7}{|c|}{ 7855-1 } & & \\
\hline $12 / 10 / 96$ & 0.460 & \pm 0.465 & 46.00 & \pm 1.50 & 70.6 & \pm 2.9 & $<0.34$ & $<0.32$ \\
\hline $01 / 15 / 97$ & -0.470 & \pm 0.255 & 72.00 & \pm 2.50 & 84.5 & \pm 4.1 & $<0.44$ & $0.21 \pm 0.18$ \\
\hline $02 / 19 / 97$ & 1.800 & \pm 0.850 & 53.00 & \pm 3.00 & 71.2 & \pm 3.6 & $<0.36$ & $0.50 \pm 0.16$ \\
\hline $03 / 18 / 97$ & 0.555 & \pm 0.536 & 59.19 & \pm 3.33 & 53.2 & \pm 2.5 & $<0.40$ & $0.07 \pm 0.08$ \\
\hline $04 / 24 / 97$ & -0.060 & \pm 0.330 & 48.09 & \pm 3.14 & 63.1 & \pm 2.0 & $<0.20$ & $0.34 \pm 0.08$ \\
\hline $05 / 20 / 97$ & 0.780 & \pm 0.440 & 36.10 & \pm 1.85 & 55.6 & \pm 3.8 & $<0.37$ & $<0.34$ \\
\hline $06 / 23 / 97$ & -0.550 & \pm 0.200 & 51.79 & \pm 2.03 & 46.1 & \pm 2.3 & $<0.36$ & $0.58 \pm 0.07$ \\
\hline $07 / 25 / 97$ & 0.260 & \pm 0.460 & 81.39 & \pm 3.70 & 83.6 & \pm 3.7 & $<0.33$ & $0.53 \pm 0.11$ \\
\hline $08 / 21 / 97$ & -0.220 & \pm 0.570 & 92.49 & \pm 2.96 & 93.6 & \pm 4.0 & $<0.41$ & $0.34 \pm 0.15$ \\
\hline
\end{tabular}

Radionuclide data are in $\mathrm{Bq} / \mathrm{L}$, mean \pm 1 standard error (counting error only); blank spaces indicate analysis not performed.

- Gross beta analysis does not include tritium. 
Table B.5. SWSA 5 North groundwater radionuclide data.

\begin{tabular}{|c|c|c|c|c|c|c|c|c|c|c|}
\hline \multirow{2}{*}{$\frac{\text { Well }}{513}$} & Gross $\alpha$ & Gross $\beta^{b}$ & \multirow{2}{*}{$\frac{{ }^{137} \mathrm{Cs}}{<0.149}$} & \multirow{2}{*}{$\frac{{ }^{60} \mathrm{Co}}{<0.136}$} & \multicolumn{3}{|c|}{${ }^{244} \mathrm{Cm}$} & \multicolumn{3}{|c|}{${ }^{241} \mathrm{Am}$} \\
\hline & $0.020 \pm 0.020$ & $0.31 \pm 0.08$ & & & 0.000 & \pm & 0.003 & -0.003 & \pm & 0.002 \\
\hline 514 & $0.031 \pm 0.030$ & $0.18 \pm 0.06$ & $<0.255$ & $<0.232$ & -0.003 & \pm & 0.004 & 0.005 & \pm & 0.004 \\
\hline 516 & $6.3 \pm 0.4$ & $0.52 \pm 0.09$ & $<0.276$ & $<0.255$ & 5.6 & \pm & 0.3 & 0.026 & \pm & 0.006 \\
\hline 517 & $0.017 \pm 0.020$ & $0.17 \pm 0.07$ & $<0.202$ & $<0.272$ & -0.016 & \pm & 0.006 & 0.002 & \pm & 0.003 \\
\hline 518 & $0.022 \pm 0.020$ & $0.22 \pm 0.08$ & $<0.227$ & $<0.242$ & 0.001 & \pm & 0.003 & -0.003 & \pm & 0.005 \\
\hline 519 & $0.001 \pm 0.003$ & $0.08 \pm 0.06$ & $<0.352$ & $<0.310$ & -0.010 & \pm & 0.009 & 0.010 & \pm & 0.008 \\
\hline 520 & $0.026 \pm 0.030$ & $0.16 \pm 0.09$ & $<0.223$ & $<0.278$ & 0.002 & \pm & 0.003 & -0.009 & \pm & 0.010 \\
\hline 521 & $0.013 \pm 0.011$ & $0.86 \pm 0.10$ & $<0.329$ & $<0.315$ & 0.005 & \pm & 0.002 & 0.003 & \pm & 0.001 \\
\hline 522 & $-0.030 \pm 0.018$ & $0.17 \pm 0.08$ & $<0.250$ & $<0.225$ & 0.001 & \pm & 0.003 & 0.011 & \pm & 0.008 \\
\hline 523 & $0.044 \pm 0.031$ & $-0.037 \pm 0.059$ & $<0.225$ & $<0.278$ & 0.001 & \pm & 0.001 & 0.005 & \pm & 0.002 \\
\hline 524 & $-0.050 \pm 0.020$ & $0.13 \pm 0.07$ & $<0.240$ & $<0.323$ & 0.010 & \pm & 0.014 & 0.012 & \pm & 0.010 \\
\hline 525 & $0.048 \pm 0.022$ & $0.10 \pm 0.06$ & $<0.225$ & $<0.276$ & -0.008 & \pm & 0.002 & 0.002 & \pm & 0.000 \\
\hline 708 & $0.060 \pm 0.040$ & $0.020 \pm 0.060$ & $<0.122$ & $<0.143$ & 0.000 & \pm & 0.003 & 0.000 & \pm & 0.003 \\
\hline 715 & $0.048 \pm 0.034$ & $0.22 \pm 0.06$ & $<0.214$ & $<0.289$ & 0.005 & \pm & 0.007 & 0.003 & \pm & 0.006 \\
\hline 716 & $0.030 \pm 0.030$ & $0.25 \pm 0.07$ & $<0.254$ & $<0.329$ & 0.010 & \pm & 0.003 & 0.002 & & 0.004 \\
\hline
\end{tabular}

- All data are in Becquerel per liter, mean \pm 1 standard error (counting error only).

${ }^{b}$ Gross beta analysis does not include tritium.

Table B.6. Radionuclide data for SWSA 5 N seeps. ${ }^{a}$

\begin{tabular}{ccccccc}
\hline Seep & Gross $\alpha$ & ${ }^{241} \mathrm{Am}$ & ${ }^{244} \mathrm{Cm}$ & Gross $\beta^{b}$ & ${ }^{137} \mathrm{Cs}$ & ${ }^{60} \mathrm{Co}$ \\
\hline 258 & $0.21 \pm 0.08$ & $0.008 \pm 0.002$ & $0.15 \pm 0.06$ & $0.36 \pm 0.10$ & $<0.266$ & $<0.288$ \\
\hline
\end{tabular}

- All data are in Becquerel per liter, mean \pm 1 standard error (counting error only).

${ }^{c}$ Gross beta analysis does not include tritium. 
Table B.7. Analytical data for SWSA $5 \mathrm{~N}$ groundwater samples."

\begin{tabular}{|c|c|c|c|c|c|c|c|c|c|c|c|c|c|c|c|c|}
\hline Well & $\mathbf{B r}$ & $\mathrm{Cl}$ & $F$ & $\mathrm{NO}_{3}$ & $\mathrm{SO}_{4}$ & AI & $\mathbf{B a}$ & $\mathrm{Ca}$ & $\mathbf{F e}$ & $\mathbf{K}$ & $\mathbf{M g}$ & Mn & $\mathbf{N a}$ & SI & Sr & $\mathrm{Zn}$ \\
\hline 513 & $<0.1$ & 3.7 & $<0.1$ & 0.33 & 16 & $<0.05$ & 0.18 & 59 & $<0.10$ & $<2.0$ & 7.3 & 0.020 & 5.0 & 7.6 & 0.17 & 0.020 \\
\hline 514 & $<0.1$ & 5.2 & $<0.1$ & 0.88 & 22 & $<0.05$ & 0.14 & 76 & $<0.10$ & 2.7 & 12 & 0.013 & 5.4 & 6.2 & 0.25 & 0.011 \\
\hline 516 & $<0.1$ & 3.2 & $<0.1$ & 16 & 31 & $<0.05$ & 0.22 & 98 & $<0.10$ & $<2.0$ & 14 & 0.03 & 14 & 7.1 & 0.11 & 0.007 \\
\hline 517 & $<0.1$ & 6.7 & $<0.1$ & 0.51 & 323 & $<0.05$ & 0.04 & 118 & $<0.10$ & 2.1 & 52 & 0.23 & 21 & 6.9 & 0.32 & 0.008 \\
\hline 518 & $<0.1$ & 3.2 & $<0.1$ & 2.1 & 178 & $<0.05$ & 0.12 & 102 & $<0.10$ & 3.2 & 49 & 0.11 & 13 & 4.0 & 0.22 & 0.012 \\
\hline 519 & $<0.1$ & 3.8 & $<0.1$ & 0.32 & 42 & $<0.05$ & 0.18 & 118 & $<0.10$ & 3.6 & 22 & 0.08 & 6.7 & 4.2 & 0.14 & 0.011 \\
\hline 520 & $<0.1$ & 5.0 & $<0.1$ & 1.6 & 48 & $<0.05$ & 0.33 & 114 & $<0.10$ & $<2.0$ & 10 & 0.69 & 5.4 & 9.8 & 0.11 & 0.022 \\
\hline 521 & $<0.1$ & 32 & $<0.1$ & 0.25 & 980 & $<0.05$ & 0.08 & 325 & 1.8 & 4.8 & 110 & 3.1 & 56 & 10 & 0.26 & 0.008 \\
\hline 522 & $<0.1$ & 2.2 & $<0.1$ & 2.1 & 195 & 0.12 & 0.10 & 62 & $<0.10$ & 3.6 & 9.5 & 0.008 & 16 & 5.2 & 0.45 & 0.029 \\
\hline 523 & $<0.1$ & 1.6 & $<0.1$ & 1.1 & 32 & $<0.05$ & 0.12 & 106 & 0.06 & $<2.0$ & 15 & 0.13 & 6.3 & 5.5 & 0.36 & 0.010 \\
\hline 524 & $<0.1$ & 7.7 & 0.98 & $<0.1$ & 37 & $<0.05$ & 0.07 & 58 & 0.90 & 3.3 & 10 & 0.41 & 62 & 6.6 & 0.33 & 0.030 \\
\hline 525 & $<0.1$ & 9.5 & $<0.1$ & 5.2 & 23 & $<0.05$ & 0.18 & 110 & $<0.10$ & $<2.0$ & 22 & 0.42 & 23 & 7.2 & 0.20 & 0.023 \\
\hline 708 & $<0.1$ & 2.6 & $<0.1$ & $<0.1$ & 35 & $<0.05$ & 0.13 & 83 & $<0.05$ & 2.5 & 12 & 1.2 & 5.6 & 4.0 & 0.26 & 0.078 \\
\hline 715 & $<0.1$ & 3.3 & $<0.1$ & 1.8 & 56 & $<0.05$ & 0.10 & 95 & $<0.05$ & 2.9 & 23 & 0.25 & 5.1 & 4.8 & 0.44 & 0.008 \\
\hline 716 & $<0.13$ & 0.86 & 0.13 & 0.51 & 8.6 & $<0.05$ & 0.04 & 42 & 0.74 & 13.4 & 2.7 & 0.07 & 2.2 & 3.0 & 0.17 & 0.02 \\
\hline
\end{tabular}

- All data are in mg/L. 
ORNL/M-6163

\section{INTERNAL DISTRIBUTION}

(2) . G. R. Cunningham

T. F. Scanlan

D. F. Hall

S. D. VanHoesen

G. K. Jacobs

D. S. Marshall

B. C. McClelland

(3)

Central Research Library

ESD Library

(3)

T. E. Myrick

(2) Laboratory Records Dept.

Laboratory Records, ORNL-RC

\section{EXTERNAL DISTRIBUTION}

E. G. Cumesty, ORNL Site Manager, Department of Energy, Oak Ridge National Laboratory, P.O. Box 2008, Oak Ridge, TN. 37831-6269

Office of Assistant Manager for Energy Research and Development, U.S. Department of Energy Oak Ridge Operations, P. O. Box 2001, Oak Ridge, TN. 37831-8600

(2) Office of Scientific and Technical Information, P. O. Box 62, Oak Ridge, TN. 37831 